UNIVERSIDADE DE SÃO PAULO

FACULDADE DE CIÊNCIAS FARMACÊUTICAS

PROGRAMA DE PÓS-GRADUAÇÃO EM CIÊNCIA DOS ALIMENTOS ÁREA DE NUTRIÇÃO EXPERIMENTAL

BRUNA KEMPFER BASSOLI

Ácido fólico: efeitos paradoxais na promoção da hepatocarcinogênese em ratos

São Paulo

2009 


\begin{abstract}
UNIVERSIDADE DE SÃO PAULO FACULDADE DE CIÊNCIAS FARMACÊUTICAS

PROGRAMA DE PÓS-GRADUAÇÃO EM CIÊNCIA DOS ALIMENTOS ÁREA DE NUTRIÇÃO EXPERIMENTAL
\end{abstract}

BRUNA KEMPFER BASSOLI

\title{
Ácido fólico: efeitos paradoxais na promoção da hepatocarcinogênese em ratos
}

Tese apresentada para obtenção do grau de Doutor Orientador: Prof. Tit. Fernando Salvador Moreno

São Paulo 
Ficha Catalográfica

Elaborada pela Divisão de Biblioteca e

Documentação do Conjunto das Químicas da USP.

Bassoli, Bruna Kempfer

B322a Ácido fólico: efeitos paradoxais na promoção da hepatocarcinogênese em ratos / Bruna Kempfer Bassoli. - São Paulo, 2009. $158 \mathrm{p}$.

Tese (doutorado) - Faculdade de Ciências Farmacêuticas da Universidade de São Paulo. Departamento de Alimentos e Nutrição Experimental

Orientador: Moreno, Fernando Salvador

1. Nutrição experimental : Ciência dos alimentos 2. Ácido fólico : Ciência dos alimentos I. T. II. Moreno, Fernando Salvador, orientador. 


\title{
BRUNA KEMPFER BASSOLI
}

\author{
Ácido fólico: efeitos paradoxais na \\ promoção da hepatocarcinogênese em ratos.
}

Tese apresentada ao Programa de Pós-Graduação em Ciência do Alimentos Nutrição Experimental da Faculdade de Ciências Farmacêuticas da Universidade de São Paulo

\section{Comissão Julgadora}

da tese para obtenção do grau de Doutor

\author{
Prof. Tit. Fernando Salvador Moreno \\ Universidade de São Paulo-FCF \\ (Orientador/Presidente) \\ $1^{\circ}$. examinador \\ $2^{\circ}$. examinador \\ $3^{0}$. examinador \\ $4^{0}$. examinador
}

São Paulo, de de 2010. 
Ao meu pai Denis e à minha mãe Marlene, por serem o início, o meio e o exemplo para eu estar concluindo meu Doutoramento Ao meu falecido avô Nelson pela lição para a vida de que "Se melhorar, estraga." Com carinho dedico este trabalho. 


\section{AGRADECIMENTOS}

Ao meu professor orientador e amigo a quem muito admiro Dr. Fernando Salvador Moreno, pela oportunidade e confiança dedicadas a uma biomédica que veio do Paraná com seu pai para USP pela primeira vez há 6 anos atrás com uma paixão pelos alimentos funcionais e sabendo algo sobre perfusão de fígado e Bioestatística; pela paciência, mas também pela cobrança; por todas as nossas conversas e pela lição de vida, que foi aprendida e será sempre repassada. Conte comigo sempre!

Ao professor Thomas Prates Ong por estar sempre pronto para ajudar, corrigir e ensinar, pelos momentos de descontração e pela amizade.

Aos meus companheiros de todas as horas que tiveram participação essencial na minha vida pessoal e profissional Carlos Eduardo Andrade Chagas e Giulianna Paola Cruzetta.

Ao Renato Heidor pela alegria, amizade, prestatividade e apoio técnico na elaboração do projeto FAPESP e execução do mesmo, especialmente no que se refere à técnica do Cometa.

Aos estagiários, ou melhor, aprendizes e amigos que estiveram comigo nesses anos de Doutorado Wesley, Juliana e Mariana.

À Aline de Conti, por me ensinar de biologia molecular à “desordem”...afinal, nem, sempre o excesso de perfeccionismo é a solução de todos os problemas. À Clarissa por se preocupar e por estar sempre pronta para ouvir e ajudar. Às amigas de potinho e de todas as horas Alessandra e Letícia. Aos demais amigos de laboratório Joice, Ernesto, Mônica, Aderuza, Fábia, Rodrigo e Eduardo pelo companheirismo e pelos bons momentos nesses quatro anos que se passaram.

Aos professores Inar Alves de Castro (FCF) e Júlio César Rodrigues Pereira (FSP) por terem me aceito como sua monitora em suas disciplinas, me deixado aprender ao corrigir e ensinar e feito aumentar ainda mais minha paixão pela Bioestatística. 
Aos professores Helenir, Gláucia e Rui Sérgio da UEL (Londrina-PR) por terem sido fundamentais na minha formação, exemplo e incentivo maior para eu ter vindo para o programa de excelência em Ciência de Alimentos do Brasil na USP.

A Deus, por ter me mostrado no momento certo o significado da palavra irmã, ao trazer a Kaísa de volta para a minha vida e da palavra religião, ao trazer para minha vida meus padrinhos e a Sabrina.

Aos que sempre estiveram lá para cuidar de mim, incondicionalmente...Dilsa, professores da Overall, Bel, Magda, Paty e funcionários da banca da água de côco.

Às amigas de apartamento, de conversar, de comer, de ir ao parque, de sair, de rir, de chorar, de viver juntas cada dia como se fosse único e por isso mesmo muito especial...Kaísa, Sabrina, Renata e Maria.

Aos companheiros nas horas mais difíceis Pequerrucho, Petra (ambos “in memorian”) e Mausi.

De modo geral aos que me incentivaram e ajudaram, mas também aos que me desestimularam e atrapalharam, por terem me dado mais forças para seguir.

Ao Departamento de Alimentos e Nutrição Experimental pela oportunidade de realizar este trabalho e aprofundar meus conhecimentos no Doutorado.

Ao Biotério do Conjunto das Químicas pelo fornecimento dos animais e apoio técnico para a realização deste trabalho.

Às agências de fomento, FAPESP, pelo apoio financeiro para execução desse projeto e CNPQ pela concessão da minha bolsa.

Meu eterno reconhecimento, muito obrigada por tudo! 


\section{RESUMO}

BASSOLI, B. K. Ácido fólico: efeitos paradoxais na promoção da hepatocarcinogênese em ratos. 2009. 158 f. Tese (Doutorado em Ciência dos Alimentos - Nutrição Experimental) - Faculdade de Ciências Farmacêuticas, Universidade de São Paulo, São Paulo, 2009.

A suplementação com ácido fólico (AF) apresenta efeitos quimiopreventivos, porém, pode aumentar o risco de desenvolvimento e acelerar a progressão do câncer se ocorrer em doses elevadas ou após a ocorrência de lesões pré-neoplásicas (LPN). O AF é essencial na síntese de novo de purinas e timidalato e consequentemente na síntese, replicação e reparo do DNA, proliferação celular e apoptose. Assim, a deficiência pode implicar em danos ao DNA e erros na sua replicação e reparo, processos importantes na carcinogênese, onde as células apresentam taxas de replicação e divisão aceleradas, e é possível que a suplementação module estes processos. Além disso, como AF ocupa uma posição de destaque no metabolismo dos grupamentos metila pode exercer efeitos sobre a hipometilação global do DNA e o aumento da expressão de proto-oncogenes como o c-myc, fenômenos característicos da hepatocarcinogênese. Assim, objetivando-se avaliar os efeitos do AF na promoção da hepatocarcinogênese em ratos Wistar, desenvolveu-se o modelo do "Hepatócito Resistente" e administrou-se por entubação gástrica diariamente, durante 5 semanas, o AF $(0,16 ; 0,32$; ou 0,64 mg / $100 \mathrm{~g}$ de peso / dia) ou água (0,25 mL / $100 \mathrm{~g}$ de peso / dia). Então, avaliou-se as LPN hepáticas presentes visíveis à macroscopia e microscopia (GST-P), a proliferação celular (BrdU) e a apoptose (microscopia de fluorescência) no tecido hepático ao redor das LPN e nas LPN persistentes e em remodelação, a intensidade de danos ao DNA ("Cometa” alcalino), e o padrão de metilação global (Dot Blot) e a expressão do c-myc (RT-PCR) especificamente em LPN microdissecadas. Apesar de não ter alterado a incidência e multiplicidade das LPN, o tratamento com AF 0,32 mg / 100 g promoveu um aumento na porcentagem de lesões $\geq 1 \mathrm{~mm}$ e o com AF 0,64 mg / 100 g a diminuição na porcentagem dessa lesões com relação ao grupo água $(\mathrm{p}<0,05)$. De modo semelhante, observou-se na análise das LPN GST-P positivas que o AF 0,32 mg / $100 \mathrm{~g}$ promoveu aumento e o AF 0,64 mg / $100 \mathrm{~g}$ inibiu o processo carcinogênico, embora não se tenha observado diferenças significantes no número, área e porcentagem da área do corte ocupada pelas LPN. Apesar de não ter modulado significativamente o desenvolvimento das LPN, o AF nas doses de 0,32 e 0,64 mg / $100 \mathrm{~g}$ inibiu a proliferação celular nas LPN persistentes $(\mathrm{p}<0,05)$. A contagem dos corpúsculos apoptóticos permitiu constatar uma possível inibição da apoptose nas LPN persistentes e em remodelação com caráter dose-dependente $(\mathrm{p}>0,05)$. De acordo com a análise do comprimento dos cometas, houve um aumento dos danos ao DNA no modelo de hepatocarcinogênese e ausência de efeito do AF nesse processo ( $>>0,05)$. O padrão de metilação global do DNA e a expressão do c-myc nas LPN microdissecadas não foram significativamente alterados pelo tratamento com diferentes doses de AF, embora, em geral, se tenha observado uma tendência dos tratamentos com AF promoverem hipometilação e aumento da expressão de c-myc. Os resultados obtidos, em conjunto, auxiliaram na caracterização das ações paradoxais (inibitórias e promotoras) que o AF apresenta na etapa de promoção da carcinogênese, de forma que a dose e o estágio do desenvolvimento neoplásico em que se inicia a suplementação demonstraram ser críticos e, por isso, indicam necessidade de cautela acerca da fortificação com o AF, uma das maiores intervenções de saúde pública que expôs a população a elevadas concentrações de AF sintético.

Palavras-chave: Ácido fólico. Hepatocarcinogênese. DNA. Metilação. Expressão gênica. 


\begin{abstract}
BASSOLI, B. K. Folic acid: paradoxical effects during promotion of hepatocarcinogenesis in rats. 2009. 158 f. Tese (Doutorado em Ciência dos Alimentos Nutrição Experimental) - Faculdade de Ciências Farmacêuticas, Universidade de São Paulo, São Paulo, 2009.
\end{abstract}

Folic acid (FA) supplementation shows chemopreventive effects, however, it may increase the risk of development and accelerate cancer progression in case of high doses or after preneoplastic lesions (PNL) are established. FA is essential on de novo synthesis of purine and thymidalate and, consequently, on DNA synthesis, replication and repair, cell proliferation and apoptosis. Thus, its deficiency may cause DNA damage and replication and repair mistakes, important processes on carcinogenesis, where cells present high replication rates and accelerated division, and is possible that supplementation modulates these processes. Besides, as FA has a central role on methyl group metabolism, it may have effects on hepatocarcinogenesis peculiar events such as DNA global hypomethylation and on the increased expression of proto-oncogenes like c-myc. Objecting the evaluation of FA effects during hepatocarcinogenesis promotion in Wistar rats, the "Resistant Hepatocyte" model was developed and water (0.25 mL / 100 g BW / day) or FA (0.16; 0.32; or 0.64 mg / 100 g BW / day) were supplemented daily by gavage for 5 weeks. Then, hepatic PNL detected by macroscopy and microscopy (GST-P), cell proliferation (BrdU) and apoptosis (fluorescence microscopy) on surrounding tissue, persistent and remodeling PNL, DNA damage (alcaline Comet assay), DNA global methylation pattern (Dot Blot) and c-myc expression (RT-PCR) specifically in microdissected PNL were evaluated. Even though FA treatment was not able to change incidence and multiplicity of PNL, the treatment with $0.32 \mathrm{mg} / 100 \mathrm{~g}$ of FA increased the percentage of lesions $\geq 1 \mathrm{~mm}$ whereas with $0.64 \mathrm{mg} / 100 \mathrm{~g}$ of FA diminished the percentage of these lesions, compaired to the water group $(\mathrm{p}<0.05)$. Similarly, it could be observed in PNL positive GST-P analysis that FA $0.32 \mathrm{mg} / 100 \mathrm{~g}$ enhanced and FA $0.64 \mathrm{mg}$ / $100 \mathrm{~g}$ inhibited the carcinogenic process, although it was not possible to detect significant differences on number, size and area of liver section occupied by GST-P positive PNL. Despite the fact that PNL development was not significantly modulated by FA, FA 0.32 and $0.64 \mathrm{mg} / 100 \mathrm{~g}$ dosages inhibited cell proliferation on persistent PNL $(\mathrm{p}<0.05)$. The apoptotic body count allowed to identify a possible dosage-dependent apoptosis inhibition on persistent and remodeling PNL $(\mathrm{p}>0.05)$. According to the analysis of comet length, the hepatocarcinogenesis model increased DNA damage but FA showed lack of effect on this process $(\mathrm{p}>0.05)$. DNA global methylation pattern and $c$-myc expression in microdissected PNL were not significantly altered by treatment with different dosages of FA, although a trend towards promotion of hypomethylation and increase on c-myc expression was observed. Altogether, the obtained results helped to characterize the paradoxical action (both inhibitory and promoting) that FA has on carcinogenesis promotion step, in such a way that the dosage and the stage of neoplastic development in which supplementation begins seems to be critical, highlighting the necessity of caution with FA fortification, one of the biggest public health interventions taken that exposes the population to high concentrations of synthetic FA.

Key-words: Folic acid. Hepatocarcinogenesis. DNA. Methylation. Genic Expression. 


\section{LISTA DE ILUTRAÇÕES}

Figura 1 Ácido fólico.

Figura 2 Visão geral do metabolismo dos grupamentos metila e sua relação com os processos de síntese e metilação do DNA.

Figura 3 Ações distintas e opostas da deficiência e da suplementação com ácido fólico nas 37 diferentes etapas da carcinogênese.

Figura 4 Representação esquemática do protocolo experimental para avaliação das eventuais 50 atividades quimiopreventivas do ácido fólico quando administrado por 5 semanas consecutivas durante a etapa de promoção a ratos Wistar submetidos ao modelo de hepatocarcinogênese do Hepatócito Resistente.

Figura 5 Foto do equipamento de microdissecção.

Figura 6 Fotomicrografia de LPN hepática corada com hematoxilina e eosina (H\&E) a ser 61 microdissecada (A) e das etapas da microdisseccão (B a D).

Figura 7 Dot Blot realizado a partir de diversas concentrações de DNA genômico para a 64 avaliação do padrão global de metilação do DNA.

Figura 8 Evolução do peso corpóreo dos ratos Wistar normais ou tratados com água ou ácido 72 fólico em diferentes concentrações (0,16; 0,32; ou 0,64 mg / 100 g de peso corpóreo / dia ) durante 5 semanas consecutivas da promoção do modelo de hepatocarcinogênese do RH.

Figura 9 Fotografia digital de fígado de rato Wistar com LPN hepáticas, em forma de 74 nódulos de hepatócito.

Figura 10 Fotomicrografias de cortes histológicos de fígado de rato Wistar submetido ao 76 modelo do RH com LPN GST-P positivas persistentes (A) e em remodelação (B).

Figura 11 Número de LPN / cm² de corte histológico. 76

Figura 12 Área média das LPN $\left(\mathrm{mm}^{2}\right) . \quad 77$

Figura 13 Porcentagem da área do corte histológico ocupada por LPN. 77

Figura 14 Fotomicrografia de hepatócitos com núcleos marcados positivamente pela 5-bromo- 79 2-desoxiuridina (BrdU) no tecido ao redor de uma LPN e no interior de LPNs GSTP positivas persistentes (A) e em remodelação (B).

Figura 15 Quantificação da proliferação celular hepática. 
Figura 16 Fotomicrografia de corpúsculos apoptóticos detectado em corte histológico de 81 fígado de rato Wistar submetido ao modelo do RH e corado com hematoxilina e eosina (H\&E) em luz normal transmitida (A), e a mesma região do corte observada em microscopia de fluorescência (B).

Figura 17 Quantificação de corpúsculos apoptóticos por $\mathrm{mm}^{2}$ em LPN persistentes, em 82 remodelação e ao redor delas (“surrounding”).

Figura 18 Fotomicrografias de "cometas" de rato Wistar normal (A) ou submetido ao modelo 83 do RH (B).

Figura 19 Gráfico representativo do comprimento dos cometas e indicativo da intensidade de 84 quebra do DNA das células hepáticas.

Figura 20 Metilação global do DNA em tecido hepático inteiro (A) e microdissecado (B). 85

Figura 21 Avaliação da expressão hepática de c-myc em tecido hepático inteiro (A) e 87 microdissecado (B).

Figura 22 Análise exploratória dos efeitos das diferentes doses de ácido fólico suplementadas. 88

Figura 23 Comportamento dos biomarcadores utilizados na avaliação das LPN persistentes em 89 resposta aos tratamentos com diferentes doses de ácido.

Figura 24 Dispersões dos grupos experimentais segundo as informações dos biomarcadores 90 utilizados para avaliar as LPN persistentes retidas nos componentes principais 1 e 2 (A) e 1 e 3 .

Figura 25 Possíveis efeitos metabólicos da suplementação com AF nos processos de metilação 98 do DNA e proliferação celular.

Figura 26 Representação da curva de resposta dos efeitos de doses distintas do AF na 107 carcinogênese. 


\section{LISTA DE TABELAS}

Tabela 1 Composição do alimento completo para roedores NuvilabCR1.

Tabela 2 Pesos corpóreos e dos fígados de ratos normais ou tratados com água ou ácido fólico em diferentes concentrações $(0,16 ; 0,32$; ou 0,64 $\mathrm{mg} / 100 \mathrm{~g}$ de peso corpóreo / dia) durante 5 semanas consecutivas da promoção do modelo de hepatocarcinogênese do RH.

Tabela 3 Incidência, multiplicidade e \% de LPN hepáticas visíveis à macroscopia observadas por ocasião da eutanásia de ratos tratados com água ou ácido fólico em diferentes concentrações $(0,16$; 0,32; ou $0,64 \mathrm{mg} / 100$ g de peso corpóreo / dia) durante 5 semanas consecutivas da promoção do modelo de hepatocarcinogênese do RH.

Tabela 4 Caracterização dos componentes principais: autovalores e porcentagem de retenção da variabilidade e da informação contida nos biomarcadores.

Tabela 5 Correlações entre os biomarcadores e os componentes principais. 


\section{LISTA DAS PRINCIPAIS ABREVIATURAS E SIGLAS}

2-AAF - 2-acetilaminofluoreno

$\mathrm{ACF}=$ focos de criptas aberrantes

$\mathrm{AF}=$ ácido fólico

$\mathrm{BrDU}=$ 5-bromo-2-desoxiuridina

$\mathrm{CP}=$ componente principal

DEN = dietilnitrosamina

DNMT = DNA metiltransferases

Grupo AF 16= 0,16 mg AF / 100 g de peso corpóreo/dia (8 vezes a RDA)

Grupo AF 32=0,32 mg AF / 100 g de peso corpóreo/dia (16 vezes a RDA)

Grupo AF 64= 0,64 mg AF / 100 g de peso corpóreo/dia (32 vezes a RDA)

Grupo H2O= 0,25 mL água / 100 g de peso corpóreo/dia

Grupo N= normal

GST-P - glutationa-S-transferase, forma placentária

$\mathrm{H} \& \mathrm{E}=$ hematoxilina e eosina

HCC = hepatocarcinoma celular

$\mathrm{HP}=$ hepatectomia parcial

HR = Hepatócito Resistente

LPN = lesões pré-neoplásicas

MS= metionina sintetase

MT= metil transferases.

MTHFR= metileno-tetrahidro-folato-redutase

$\mathrm{P}=\mathrm{LPN}$ persistentes

PBS = solução salina tamponada com fosfato 
PCA= Análise de componentes principais

$\mathrm{R}=\mathrm{LPN}$ em remodelação

$\mathrm{RDA}=$ recommended dietary allowance - ingestão dietética recomendada

S= área ao redor das LPN (“surrounding”)

SAH= S-adenosil-homocisteína

SAM = S-adenosil-L-metionina

$\mathrm{THF}=$ tetrahidrofolato 


\section{SUMÁRIO}

1 INTRODUÇÃO 17

2 REVISÃO BIBLIOGRÁFICA 19

2.1 Ácido fólico: metabolismo e política de fortificação 19

2.2 Ácido Fólico, Nutrigenômica e carcinogênese 25

2.2.1 Ácido fólico: efeitos em nível genético (síntese e danos ao DNA), proliferação celular e 28 apoptose

2.2.2 Ácido fólico: efeitos em nível epigenético (modulação da metilação) 30

2.2.3 Proto-oncogene $c$-myc, hiperexpressão e proliferação celular 33

2.4 Efeitos distintos do ácido fólico nas diferentes etapas da carcinogênese 35

2.4.1 Ácido fólico e a carcinogênese coloretal 38

2.4.2 Ácido fólico e a carcinogênese mamária 41

2.4.3 Ácido fólico na hepatocarcinogênese 42

3 OBJETIVOS 46

3.1 Objetivo Geral 46

3.2 Objetivos Específicos 46

4 MATERIAL E MÉTODOS 47

4.1 Animais 47

4.2 Protocolo experimental e aplicação do modelo de hepatocarcinogênese do Hepatócito 48 Resistente

4.3 Aplicação da BrDU e eutanásia dos animais 51

4.4 Exame macroscópico $\quad 52$

4.5 Exames microscópicos

4.5.1 Imunoistoquímica para a GST-P

4.5.2 Dupla marcação imunoistoquímica para a GST-P e BrDU 54

4.5.3 Análise da apoptose

4.6 Avaliação de danos ao DNA 56

4.7 Microdissecção de focos e nódulos de hepatócitos e de tecido hepático considerado 59 normal ao seu redor

4.8 Efeitos do AF em biomarcadores avaliados através de técnicas de biologia molecular 61

4.8.1 Avaliação do padrão hepático de metilação global do DNA 62 
4.8.1.1 Extração de DNA do tecido hepático total ou a partir de focos e nódulos de hepatócitos e 62 de tecido hepático normal obtidos por microdissecção

4.8.1.2 Dot Blot

4.8.2 Análise da expressão hepática do proto-oncogene $c$-myc

4.8.2.1 Extração de RNA a partir de focos e nódulos de hepatócitos e de tecido hepático normal 65 obtidos por microdissecção e procedimento da transcrição reversa

4.8.2.2 RT-PCR

4.9 Análise Estatística

4.9.1 Análise Multivariada dos efeitos do AF nas LPN persistentes 68

5 RESULTADOS 71

$\begin{array}{lll}\mathbf{5 . 1} & \text { Evolução do peso corpóreo } & 71\end{array}$

5.2 Exame macroscópico dos fígados

5.3 Análise morfométrica das LPN hepáticas GST-P positivas 74

$\begin{array}{lll}5.4 & \text { Proliferação celular } & 78\end{array}$

5.5 Apoptose 80

5.6 Danos ao DNA $\quad 82$

5.7 Padrão hepático de metilação global do DNA 84

5.8 Expressão hepática do proto-oncogene c-myc 86

5.9 Visão global dos efeitos das diferentes doses do AF nas LPN persistentes 88

6 DISCUSSÃO 92

7 CONCLUSÃO 110

8 REFERÊNCIAS BIBLIOGRÁFICAS 112 


\section{INTRODUÇÃO}

Há aproximadamente dez anos atrás iniciava-se nos Estados Unidos e no Canadá uma das maiores intervenções da Nutrição e da Saúde pública dirigida pela ciência em décadas, com o objetivo de reduzir os índices de anemia e defeitos na formação do tubo neural de bebês: a adoção da fortificação compulsória das farinhas de trigo e milho com ácido fólico (AF) (ROSENBERG, 2005; KIM, 2006b), atualmente em vigor em diversos países ao redor do mundo, entre eles, o Brasil.

No entanto, com essa medida, estima-se que uma grande parcela da população passou a consumir: a) a ingestão dietética recomendada (RDA- recommended dietary allowance) para humanos de 400 microgramas / dia (possivelmente atingida através de uma dieta equilibrada), b) mais aproximadamente 200 microgramas / dia provenientes de alimentos produzidos com as farinhas fortificadas e c) mais 400 microgramas contidos em uma única dose de suplementos alimentares, cujo consumo apresenta-se em constante crescimento (ULRICH \& POTTER, 2006).

Assim, estima-se que a população dos países que adotaram a fortificação tenha dobrado o consumo habitual de AF, o que implicou em um aumento drástico nos níveis plasmáticos de AF não metabolizado, assim como de seu metabólito e principal forma plasmática, o 5-metil-tetrahidrofolato (5-metil THF), especialmente em crianças e idosos, grupo da população que apresenta hábitos particulares de alto consumo de pães e / ou suplementos alimentares (SMITH et al., 2008).

Nesse panorama, surge a preocupação acerca dos possíveis efeitos adversos dessas altas concentrações plasmáticas de AF. De fato, desde a oportunidade da implantação da fortificação, eram desconhecidos diversos dos possíveis efeitos da suplementação do AF em doenças específicas com o é o caso do câncer. 
Sabe-se que o AF pode modular a carcinogênese por estar diretamente envolvido com os mecanismos genéticos de síntese do DNA e epigenéticos de metilação do DNA, o que o relaciona diretamente com os processos de integridade e estabilidade do DNA, proliferação celular e expressão gênica (KIM, 2007).

Nesse sentido, apesar da descrição de um grande número de estudos da literatura de efeitos benéficos do AF no processo carcinogênico em diferentes órgãos, há também estudos que sugerem que a suplementação com AF pode aumentar o risco de desenvolvimento do câncer e acelerar a progressão tumoral, principalmente se a vitamina for administrada em concentrações elevadas ou se o tratamento for iniciado após a presença de lesões préneoplásicas (KIM, 2004; 2006a; 2006b).

Assim, há cada vez mais indícios de que o AF apresenta ações paradoxais na carcinogênese, dependente da dose e do momento de intervenção (KIM et al., 1996; SONG et al., 2000 a e b; KIM 2006b, 2007; LINDZON et al., 2009), fazendo-se indispensáveis estudos do efeitos de diferentes doses de AF em modelos de carcinogênese experimental que permitam distinguir as fases pré-neoplásicas de iniciação e promoção, com é o caso do modelo de hepatocarcinogênse do "Hepatócito Resistente”. 


\section{REVISÃO BIBLIOGRÁFICA}

\section{1 Ácido fólico: metabolismo e política de fortificação}

O AF, vitamina solúvel do complexo B (Figura 1) (COZZOLINO, 2006), foi isolado em 1941 do espinafre, o que implicou em sua atual nomenclatura derivada desta observação original do composto em folhas ("leaf”) (ULRICH; POTTER, 2006). O termo genérico folato é utilizado para designar compostos com estruturas químicas e propriedades nutricionais similares. Suas principais fontes são os vegetais folhosos verdes, crucíferas, aspargo, frutas cítricas, legumes, cereais, grãos integrais, gema de ovo, fígado e outros órgãos e, uma vez que mamíferos não podem sintetizar essa vitamina, é de grande importância seu consumo diário (COZZOLINO, 2006; KIM 2007).

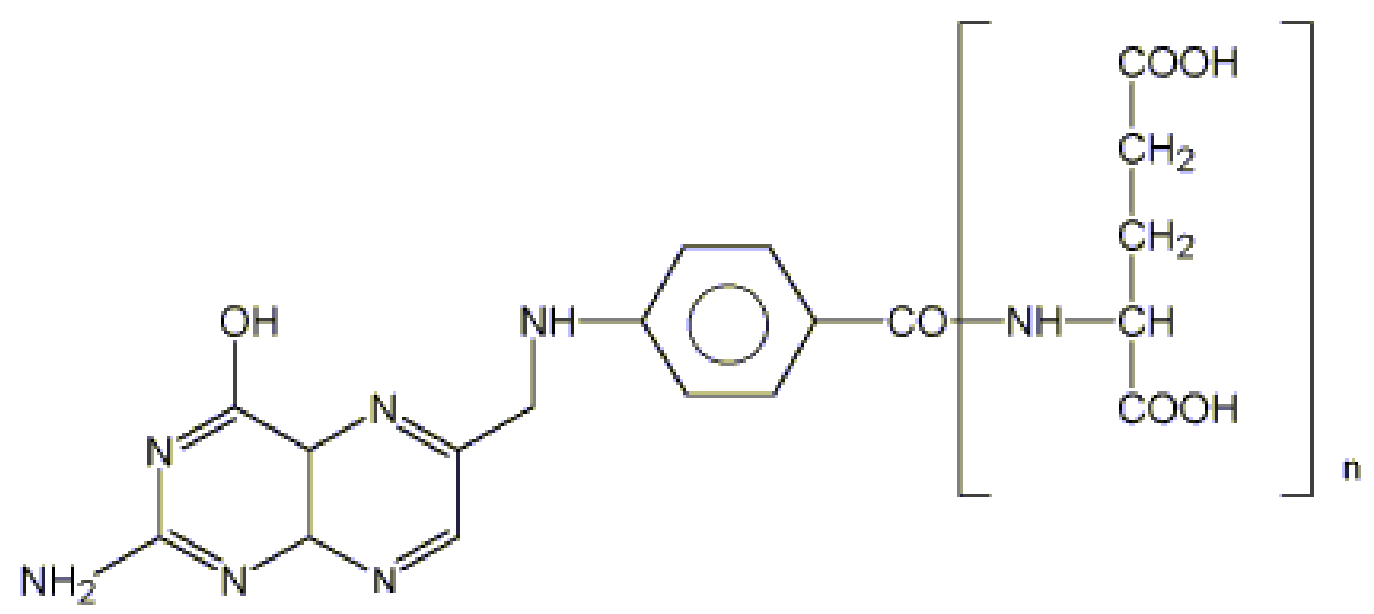

Figura 1 - Ácido fólico. Estrutura molecular do AF em sua forma de monoglutamato (COZZOLINO, 2006). 
O resumo do metabolismo e das funções do folato pode ser observado na Figura 2. Após entrar na célula, o AF ingerido pela alimentação é convertido a dihidrofolato e, logo em seguida, a tetrahidrofolato que pode seguir dois caminhos: ser convertido a 10-formiltetrahidrofolato, co-fator para a síntese de purinas ou a 5,10-metileno-tetrahidrofolato.

O 5,10-metileno-tetrahidrofolato, por sua vez, pode seguir outros dois caminhos: doar o grupamento metila para o uracil para a formação do nucleotídeo timina, que é utilizado para síntese e reparo do DNA ou em reação envolvendo a enzima metileno-tetrahidro-folatoredutase (MTHFR), ser transformado a 5-metil THF, a forma predominante na circulação, que atua como doador de grupamentos metil $\left(\mathrm{CH}_{3}\right)$ para a remetilação da homocisteína a metionina que, em reação catalisada pela enzima metionina adenosiltransferase (MAT's) reage com ATP para formar a S-adenosilmetionina (SAM), o doador universal de grupamentos metil para a maioria das reações biológicas de metilação, como é o caso da metilação do DNA. Assim, a MTHFR constitui um elo crítico no metabolismo do folato, uma vez determina o balanço entre os processos de metilação ou síntese de DNA (nucleotídeos) (STANGER, 2002; ROSS, 2003; ULRICH, 2005; LARSSON et al., 2006). 


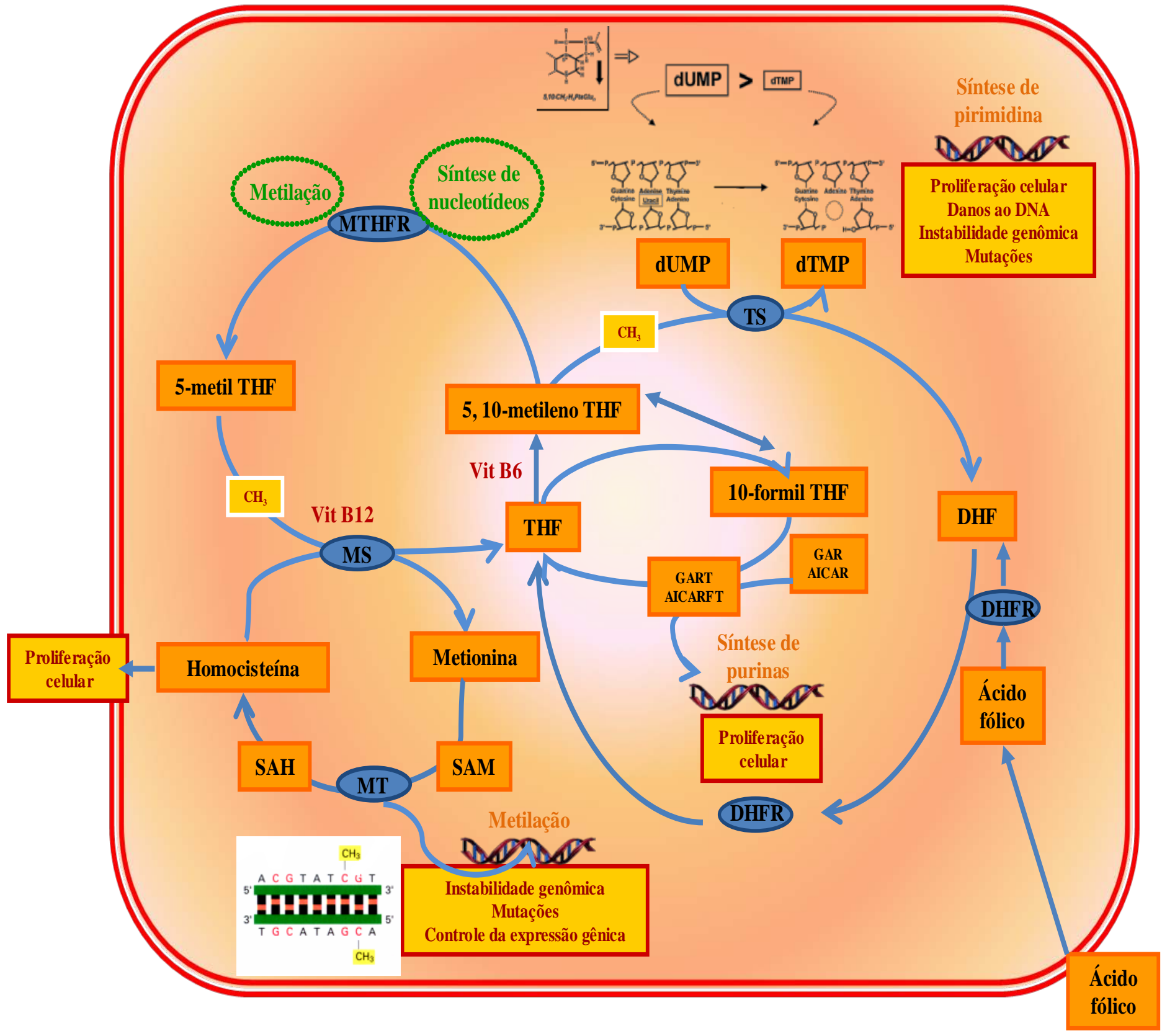

Figura 2 - Visão geral do metabolismo dos grupamentos metila e sua relação com os processos de síntese e metilação do DNA. DHF, dihidrofolato; THF, tetrahidrofolato; dUMP, desoxiuridilato; dTMP, desoxitimidalato; GART, glicinamida ribonucleotídeo transformilase; AICARFT 5-amino-imidazole-4-carboxamida ribinucleotídeo trasnformilase; GAR, glicinamida ribonucleotídeo; AICAR, 5-aminoimidazole-4-carboxamida ribinucleotídeo; SAM, S-adenosilmetionina; SAH, S-adenosil-homocisteína; DHFR, Dihidrofolato redutase; TS, Timidalato sintetase; MTHFR, metileno-tetrahidro-folato-redutase; MS, Metionina sintetase; MT, Metil transferases. Adaptado de Ulrich (2005). 
Com relação à sua biodisponibilidade, o folato é degradado por uma enzima presente na borda-em-escova intestinal, a glutamato carboxipeptidase II e entra nas células na forma de monoglutamato (Figura 1) basicamente através de duas famílias de receptores: o carreador de folato reduzido (RFC) e os receptores de folato (FR) (KIM, 2007).

Então, após essa forma química do folato ser conjugada intracelularmente em poliglutamatos, passa a constituir a forma de armazenamento de folato, o qual ocorre $50 \%$ no fígado (STANGER, 2002).

O AF utilizado comercialmente para aplicação em suplementos e na fortificação é uma forma sintética dessa vitamina totalmente oxidada em sua configuração monoglutamil, altamente estável e 100\% biodisponível, o que difere de todas as formas de folato encontradas naturalmente nos alimentos, que são tipicamente reduzidas, instáveis, com baixa absorção (em torno de $50 \%$ ) e biodisponibilidade (em torno de $50 \%$ menor do que o folato sintético), sendo muito sensíveis aos processos de armazenamento e preparação dos alimentos (relatam-se perdas de até 80\% durante o cozimento) (KRISHNASWAMY; NAIR, 2001; McNULTY; PENTIEVA, 2004). Assim, a ingestão de suplementos pode resultar em efeitos fisiológicos distintos do AF ingerido a partir de uma dieta equilibrada e variada.

As características de elevada biodisponibilidade do AF sintético são inclusive responsáveis pelo aumento drástico nas concentrações plasmáticas dessa vitamina nas populações submetidas à fortificação obrigatória da farinha e produtos contendo grãos e cereais a partir de 1998 em alguns países como Estados Unidos e Canadá, especialmente em crianças e usuários de suplementos alimentares (KIM, 2007; LINDZON et al., 2009).

Nesse sentido, buscando avaliar o efeito do consumo de suplementos multivitamínicos, Bashir e colaboradores (2004) observaram que tanto a deficiência quanto a super-suplementação com vitaminas (entre elas o AF) aumentaram significativamente o processo neoplásico intestinal (número de pólipos e o peso dos tumores), tendo a super - 
suplementação promovido o processo de forma mais intensa. Assim, as vitaminas parecem desempenhar um papel importante na carcinogênese.

Além disso, um amplo estudo clínico verificou um aumento da ordem de 70\% no risco total de câncer no grupo do estudo que consumiu altas doses de AF (12,5 vezes a RDA / dia) (LEHMAN et al., 2002).

Posteriormente observou-se uma associação inversa entre o consumo de folato naturalmente presente nos alimentos, mas não o sintético presente em suplementos, e o câncer de esôfago e pâncreas (LARSSON et al., 2006).

Da mesma forma, outro estudo epidemiológico sugere que um alto consumo e altos níveis plasmáticos de AF predominantemente provenientes de suplementação estão associados a um aumento no risco de câncer de cólon (VAN GUELPEN et al., 2006).

Ressalta-se que dois estudos recentes que avaliaram o risco de câncer de mama em humanos tiveram em comum um achado considerado alarmante de que uma alta ingestão de AF (predominantemente em sua forma sintética) e altos níveis plasmáticos da vitamina estão também associados com um aumento do risco do desenvolvimento do câncer de mama (LIN et al., 2008).

De fato, deve-se considerar que o AF em doses elevadas (acima da RDA) satura o mecanismo normal de absorção intestinal, o que resulta no aumento das concentrações de AF não metabolizado no plasma. Além disso, outro fator que pode influenciar nesse processo é justamente o consumo repetido, mesmo que de doses fisiológicas, de AF, podendo-se observar uma espécie de efeito cumulativo se doses repetidas forem consumidas com certa proximidade (SWEENEY et al., 2007).

Nesse contexto, surge a preocupação com a política de fortificação sendo que, especificamente no Brasil, a fortificação das farinhas de trigo e milho tornou-se recentemente obrigatória pelo Ministério da Saúde e pela Anvisa, conforme estabelecido pela resolução 
RDC n⿳ 344 de 13 de dezembro de 2002 (Anexo I), onde consta que cada $100 \mathrm{~g}$ de farinha de trigo e de milho devem conter $150 \mu \mathrm{g}$ de AF (aproximadamente 40\% da RDA). Com isso, alimentos a base de farinhas como pães, macarrão, biscoitos, misturas para bolos e salgadinhos passaram a apresentar maior quantidade de AF em sua formulação final, contribuindo para redução dos índices de anemia, defeitos na formação do tubo neural e outras doenças causadas pela deficiência de AF na população brasileira.

Desse modo, no Brasil, assim como nos demais países do mundo onde a fortificação foi implementada, a população está sendo exposta a valores de ingestão de AF sintético altos e sem precedentes (LARSSON et al., 2006; STOLZENBERG-SOLOMON et al., 2006).

A fortificação com AF representa uma das maiores intervenções em termos de saúde pública dirigida pela ciência em décadas (ROSENBERG, 2005; KIM, 2006b) e, ao mesmo tempo, um paradigma diante das evidências cada vez maiores dos benefícios do AF com relação ao desenvolvimento do tubo neural dos bebês e dos seus malefícios em promover o desenvolvimento de lesões pré-malignas e malignas pré-existentes não diagnosticadas (KIM, 2004). Inclusive há a preocupação da exposição das próprias gestantes, pois a exposição a nutrientes pode promover modificações epigenéticas nos bebês in utero e potencialmente modificar o risco de câncer (ROSS, 2003; SIE et al., 2009).

Independente do modo de ação, sabe-se que a suplementação com AF promoveu aumento do peso de tumores em animais com lesões pré ou neoplásicas pré-existentes (PELLIS et al., 2008) e, apesar de esse fato ter sido observado por vários estudos prévios em animais, vem sendo ignorado pelo epidemiologistas e profissionais de saúde pública e a política fortificação mantida.

Inclusive, estudos recentes começam a estabelecer relações temporais entre o período pós-fortificação nos Estados Unidos, Canadá e Chile e aumento da incidência de câncer coloretal. Esse fenômeno pode ser um reflexo da aceleração do desenvolvimento de LPN pré- 
existentes e indica que o início da suplementação principalmente em fases tardias da vida pode apresentar efeitos deletérios (MASON et al., 2007; LUEBECK et al., 2008; HIRSCH et al., 2009).

\section{2 Ácido Fólico, Nutrigenômica e carcinogênese}

Postulava-se, inicialmente, que havia dois principais mecanismos proeminentes, genéticos e epigenéticos respectivamente, pelos quais o AF poderia estar envolvido com a modulação da carcinogênese: a) através da indução da incorporação errônea de uracil no DNA, que pode implicar em danos cromossômicos, erros na síntese e reparo do DNA e b) através da modulação da metilação do DNA, resultando em alteração de expressão gênica de proto-oncogenes e genes supressores de tumor (LARSSON et al., 2006, KIM 2007).

Nesse sentido, uma vez que alterações genéticas e epigenéticas estão no cerne do processo carcinogênico (MORENO et al., 2002), a Nutrigenômica, uma nova ciência que estuda as interações entre nutrientes e compostos bioativos de alimentos e expressão gênica e estabilidade do DNA, apresenta-se como uma área promissora para estudos dos efeitos de compostos bioativos como o AF na carcinogênese (BULL; FENECH, 2008).

Carcinogênese é um termo geral utilizado para se denotar o desenvolvimento de neoplasias, um aumento autônomo do número de células, independente de estímulos de fatores extracelulares, como hormônios (BANNASCH, 1986; BANNASCH; ZERBAN, 1990; PITOT, 2001). Portanto, a neoplasia é um processo dinâmico caracterizado pelo desequilíbrio do tamanho da população de células, devido a um aumento da proliferação celular, diminuição da apoptose, ou ambos em conjunto (PAN et al., 2008).

A perda do controle da proliferação e a aquisição de características associadas com a progressão tumoral são conseqüências de alterações que ocorrem no conteúdo genético das 
células normais. Para que haja formação da neoplasia, é essencial que ocorra um ciclo de proliferação celular para que os danos químicos ao DNA sejam convertidos e fixados em alterações herdáveis denominadas mutações, dando início à iniciação (FARBER; SARMA, 1987; BERTRAM, 2000; MARTINEZ et al., 2003). Então, a célula alterada, por adquirir uma maior capacidade de proliferação, sofre uma expansão clonal, transmitindo geneticamente a alteração a todas as células que se originam a partir dela.

Por outro lado, a morte celular programada (apoptose) é um fenômeno de ampla ocorrência que atua de forma oposta à proliferação celular, no sentido de manter a homeostasia tecidual (PAN et al., 2008).

Sendo assim, o câncer pode ser considerado uma doença genética complexa que resulta de alterações simultâneas em genes geralmente relacionados à proliferação, diferenciação e apoptose (PARMIGIANAI; CAMARGO, 2004; PAN et al., 2008) e que se caracteriza por ser um processo longo envolvendo múltiplas etapas para a transformação das células normais em malignas, requerendo para isso, cerca de metade a 2/3 da vida das diferentes espécies, ou seja, de 20 a 40 anos, especialmente no caso de tumores sólidos em humanos (LOEB et al., 2003). Entretanto, é bastante discutível o número exato de etapas que compõe o processo carcinogênico, existindo evidências de que este ocorra em três estágios básicos denominados iniciação, promoção e progressão (PITOT, 2001; YOUNG et al., 2003; PAN et al., 2008).

A iniciação, o primeiro estágio, envolve alterações genéticas irreversíveis e permanentes na célula afetada (PITOT, 2001). Então, ocorre a evolução para o estágio de promoção por meio de expansão clonal das células iniciadas na presença contínua de um agente promotor de fonte endógena ou exógena, o que a torna uma fase reversível.

Desse modo, na promoção, ocorre a expansão clonal seletiva das células iniciadas pela ação de um agente promotor formando-se, assim, lesões pré-neoplásicas (LPN) (YOUNG et 
al., 2003). Nessa etapa os carcinogênicos também podem atuar por mecanismo nãogenotóxico, que envolve mudanças na expressão de diversos genes relacionados com o ciclo celular, diferenciação, inflamação e imunossupressão (LUCH, 2005). É importante ressaltar que devido à característica de reversibilidade dessa etapa, é necessário estímulo constante do agente promotor para que a carcinogênese progrida (PITOT, 2001) e que, por ser um processo longo e reversível, caracteriza-se como um ponto estratégico para a ação de agentes quimiopreventivos supressores, inibidores da promoção e progressão das células iniciadas (WATTENBERG, 1985).

A progressão, último estágio, é caracterizada por instabilidade cariotípica e uma contínua evolução de características independentes, como mudanças bioquímicas nas células malignas, aumento da proliferação celular, invasão e metástase (YOUNG et al., 2003).

Atualmente, o câncer é considerado importante problema de saúde pública em diversos países (JEMAL et al., 2006). De acordo com dados da Organização Mundial de Saúde o câncer é a $2^{\mathrm{a}}$ principal causa de morte no mundo. Estima-se que, principalmente devido ao envelhecimento da população global e com a adoção de estilos de vida cada vez mais “ocidentalizados”, incluindo a alimentação, em 2015 o número total de óbitos pela doença atinja 9 milhões e mais de 11 milhões em 2030 (WHO, 2006).

Estima-se ainda que nos próximos vinte anos ocorrerá um aumento de 50\% na incidência de cânceres, sendo que 1/3 poderá ser prevenido e 1/3 curável, desde que instituídas medidas para educação da população quanto à mudança de seus hábitos (WILKINSON, 2003).

Como $3^{\underline{a}}$ causa mais comum de morte devido ao câncer, destaca-se o hepatocarcinoma (WONG; NG, 2008), 15ª neoplasia com maior incidência no mundo (LOVET et al., 2003), com crescimento considerável na incidência global nos últimos anos, tornou-se uma das mais freqüentes neoplasias malignas (EMANUELE et al., 2004). 
Além disso, estima-se que o número de pacientes com HCC dobre nas próximas duas décadas (MARRERO; PELLETIER, 2006) e que a mortalidade por câncer primário de fígado tenha crescido mais rápido do que a taxa de mortalidade por qualquer outro câncer (ALTEKRUSE et al., 2009).

Há descrições de que o câncer é a segunda causa de mortalidade no Brasil (Ministério da Saúde-INCA, 2003; SICHIERI et al., 1996), e existem projeções de que a doença poderá assumir no futuro o papel de principal causa de morte por doenças na população brasileira (WÜNSCH FILHO; MONCAU, 2002). Apesar de não ser uma das neoplasias mais prevalentes, o HCC ocupa a $7^{a}$ posição em mortalidade no Brasil (INCA, 2006).

\subsection{1 Ácido fólico: efeitos em nível genético (síntese e danos ao DNA), proliferação celular e apoptose}

Uma vez que na carcinogênese as células apresentam taxas de replicação e divisão aceleradas (KIM et al., 1996; BASTEN et al., 2006), erros na replicação e reparo do DNA podem ter importantes repercussões. Assim, compostos bioativos como o AF, que é elemento essencial na sítese de novo de purinas (A e G) e do timidalato (Figura 2) e, por isso apresenta um papel essencial na replicação do DNA e na divisão celular, podem modular a carcinogênese (JAMES et al., 1994; BLOUNT et al., 1997). De fato, evidências sugerem que o AF atua na manutenção da estabilidade genômica justamente por modular os mecanismos de síntese e reparo do DNA (DUTHIE et al., 2004).

Assim, em células neoplásicas, a deficiência de folato e a interrupção do seu metabolismo implica na síntese inefetiva de DNA resultando na inibição do crescimento do tumor, o que tem sido a base da terapia anti-tumoral que utiliza agentes anti-folato (KIM et al., 1999; SONG et al., 2000b CHOI et al., 2002). 
Além disso, descreve-se que em estágios mais tardios da carcinogênese a indução da apoptose é um alvo molecular crítico e atrativo para compostos bioativos da dieta que apresentam ação anti-proliferativa. Assim, a apoptose representa um mecanismo emergente e importante pelo qual compostos bioativos dos alimentos podem exercer efeitos quimiopreventivos, ou seja, retardar, bloquear ou reverter o processo carcinogênico (PAN et al., 2008).

Porém, acredita-se que distúrbios no metabolismo do DNA e, possivelmente do RNA, estejam relacionados à produção de efeitos pró-carcinogênicos do AF (CHOI; MANSON, 2000). Inclusive, Kim (2007), em revisão, sugere que o mecanismo mais provável pelo qual a suplementação com AF pode promover a progressão de LPN já estabelecidas seria o fornecimento de precursores de nucleotídeos para as células neoplásicas em alto ritmo de proliferação celular. De fato, é sabido que células proliferando são preferencialmente supridas pelos estoques de folato (STANGER, 2002) e postula-se ainda que, pelo mesmo mecanismo, altas doses de AF poderiam promover o crescimento de neoplasias pré-existentes (STOLZENBERG-SOLOMON et al., 2006; LINDZON et al., 2009).

Ressalta-se que, em geral, há poucos estudos avaliando os efeitos da suplementação do AF em importantes biomarcadores da carcinogênese como a proliferação celular e a apoptose, especialmente em modelos de carcinogênese que permitam distinguir entre as etapas de iniciação, promoção e progressão, nas quais o AF pode apresentar efeitos distintos.

Outro fenômeno relevante ao processo carcinogênico é a ocorrência de danos ao DNA, o qual também pode ser modulado pelo AF, que é essencial na síntese de novo de purinas e timidalato, de modo que sua deficiência pode implicar na incorporação errônea de uracil ao invés de timina, e justamente a depurinação é a forma mais comum de dano espontâneo ao DNA (ROBIEN; ULRICH 2003). 
Assim, a deficiência de AF demonstrou potencializar danos ao DNA e estar associada com instabilidade genômica, defeitos no reparo, aumento em mutações e metilação aberrante do DNA, caracterizando um grau de instabilidade genômica que pode aumentar a progressão carcinogênica (BULL; FENECH, 2008). Por outro lado, estudos mostram que a suplementação com AF pode corrigir alguns desses defeitos (BLOUNT et al., 1997; KIM et al., 1997; KIM et al., 1999; CHOI et al., 2002; KIM 2007).

\subsection{2 Ácido fólico: efeitos em nível epigenético (modulação da metilação)}

Eventos genéticos não conseguem explicar isoladamente a carcinogênese em sua totalidade e apenas poucas alterações genéticas são conhecidamente responsáveis, pelos estágios pré-neoplásicos da carcinogênese (KANAI; HIROHASHI, 2007). Assim, está se tornando cada vez mais claro que alterações epigenéticas também contribuem para o desenvolvimento de lesões pré-neoplásicas e neoplásicas (WORM; GULDBERG, 2002; FEINBERG et al., 2006; JONES; BAYLIN, 2007).

Uma das principais modificações epigenéticas do genoma humano é a adição covalente de um grupamento metila na posição $5^{\prime}$ do anel de cerca de $80 \%$ das citosinas que fazem parte do dinucleotídeo CpG (ROBERTSON; JONES, 2000). Esses dinucleotídeos não metilados são encontrados frequentemente em pequenas seqüências de DNA ricas em CG, conhecidas como ilhas $\mathrm{CpG}$, as quais apresentam uma maior freqüência de dinucleotídeos CG do que o restante do genoma, compondo a região promotora de determinados genes (JIANG et al. 2004).

Ao contrário do silenciamento transcricional por modificações genéticas, eventos epigenéticos são potencialmente reversíveis, pois não interferem no conteúdo da informação 
dos genes afetados. Assim, uma alteração do padrão de metilação do DNA poderia modificar a expressão gênica tanto em células pré-neoplásicas como neoplásicas.

A metilação do DNA é considerada o processo epigenético regulatório mais importante nos mamíferos, pois é determinante para a expressão gênica, manutenção da integridade e estabilidade do DNA, modificações cromossômicas e desenvolvimento de mutações. Esse processo é catalisado pela DNA metil transferase, que transfere um grupamento metil da SAM (o mais importante doador de grupamentos metil humano) para resíduos de citosina das ilhotas CpG (Figura 2).

Como os derivados metabólicos do folato apresentam a capacidade de se ligar a unidades de um carbono, que são, entre outros, constituintes dos grupamentos metil $\left(\mathrm{CH}_{3}\right)$, essa via bioquímica deixa implícito que um adequado fornecimento de folato é um prérequesito para a metilação adequada do DNA (ROSS 2003; BOLLHEIMER et al., 2005), de modo que alterações nesse processo representam um dos mecanismos para explicar os efeitos paradoxais que o AF apresenta na carcinogênese (KIM 2004, 2007).

Padrões anormais de metilação são uma característica central do processo carcinogênico e um achado quase que universal no câncer (KIM, 1999; ULRICH, 2003; ROSS, 2003). A hipometilação do DNA genômico e a consequente ativação de protooncogenes, aumento da instabilidade genômica e das mutações, a hipermetilação da região promotora de mais de $60 \%$ dos genes supressores de tumor resultando em seu silenciamento (BAYLIN et al., 1998; JONES; BAYLIN 2002; KIM et al., 2003; LARSSON et al., 2006; STOLZENBERG-SOLOMON et al., 2006; KIM 2007) e o aumento da atividade da DNMT (BAYLIN et al., 1998) são descritos como características de células neoplásicas e que podem aumentar o risco de câncer.

A hipometilação global do DNA constitui importante evento epigenético no desenvolvimento de várias neoplasias (JONES; BAYLIN 2002; TAO et al., 2004; BASTEN 
et al., 2006). De fato, dados de humanos (CRAVO et al., 1994; LAIRD \& JAENISH, 1994) e também de tumores colônicos (KIM et al., 1996; TAO et al., 2004) e mamários de ratos (KIM et al., 2003), permitiram observar um padrão de hipometilação genômica em tecidos neoplásicos (FEINBERG et al., 1988) .

Especificamente na hepatocarcinogênese, a hipometilação do DNA ocorre em estágios pré-neoplásicos muito precoces (POGRIBNY; BELAND, 2009), levando ao estabelecimento de uma população celular epigenética reprogramada com alto potencial de progressão para células tumorais (POGRIBNY et al., 2006).

Ainda não está totalmente claro em que estágio da carcinogênese ocorre a hipometilação, o quanto esse processo é passível de reversão, especialmente por agentes da dieta e o quanto essa reversão pode interferir no desenvolvimento do processo carcinogênico (CRAVO et al., 1994).

No entanto, sabe-se que há quatro principais pontos onde os fatores da dieta podem modular a metilação do DNA:

a) fornecimento de grupamentos metil para a formação de SAM;

b) ação de grupos metil em processos de indução ou inibição da atividade da DNMT;

c) ação de grupos metil na modulação do processo de desmetilação do DNA;

d) responsividade das células a defeitos na metilação do DNA (ROSS 2003).

Assim, tanto fatores ambientais como, por exemplo, a deficiência de AF e a ingestão elevada de etanol, como fatores de exposição em nível experimental, como os carcinogênicos químicos DEN e o 2-AFF, induzem hipometilação do material genético (POIRIER, 2002; ROSS, 2003).

O folato estaria entre os fatores que influenciam a disponibilidade de SAM e podem ter impacto no processo de metilação (ROSS, 2003). 
Há relatos de que suplementação de AF em humanos com doses de 12,5; 25 e 50 vezes a RDA é capaz de aumentar a metilação genômica (CRAVO et al., 1994; KIM et al., 2001; KIM, 2004; PUFULETE et al., 2005).

Por outro lado, diferentes estudos observaram que a suplementação com AF promoveu redução da ordem de 50-60\% no grau de metilação genômica do DNA hepático (KIM et al., 1997; SONG et al., 2000a) e induziu hipometilação na mucosa retal de pacientes com adenomas colônicos (CRAVO et al., 1998).

Interessantemente, efeito semelhante foi observado com a deficiência de AF, a qual promoveu um aumento da metilação do DNA genômico do cólon (KIM et al., 1997; SOHN et al., 2003) e do fígado (SONG et al. 2000a; KOTSOPOULOS et al., 2008).

Outro mecanismo possível pelo qual a suplementação com AF pode promover a progressão de LPN já estabelecidas seria a metilação de novo da região promotora de genes supressores de tumor, inativando-os (KIM, 2007).

Assim, faz-se de grande importância a avaliação dos efeitos ainda controversos do AF no processo epigenético de metilação do DNA que está alterado na carcinogênese, especialmente em órgãos ainda pouco explorados como o fígado.

\subsubsection{Proto-oncogene $c$-myc, hiperexpressão e proliferação celular}

No processo carcinogênico uma séria de vias de transdução de sinais está alterada, mas inevitavelmente, para que possa haver alterações efetivas em nível celular, todas elas culminam com alteração da expressão gênica de uma série de genes, entre eles, os envolvidos com o ciclo celular (COLE; COWLING 2008).

Especificamente na hepatocarcinogênese destaca-se, como um dos genes mais intimamente relacionados ao processo, o oncogene c-myc (SHEN et al., 1998), que é um 
proto-oncogene de resposta imediata ao crescimento expresso em praticamente todas as células eucarióticas que, no formato de dímero com a proteína max, atua como um fator de transcrição e ativa a transcrição de genes envolvidos com a síntese de DNA, o ciclo celular e por conseqüência a proliferação celular. Esse proto-oncogene pode estar mutado e/ou hipometilado levando respectivamente a desvio de funções e aumento de expressão, caracterizando-o como oncogene (COLE; COWLING 2008).

Quando mutado, o oncogene c-myc pode passar a ser hiperexpresso e de forma persistente, o que pode estar relacionado à transcrição persistente de genes-alvo críticos e, possivelmente, uma transformação neoplásica, uma vez que esse potente oncogene coordena o crescimento e a proliferação celular desregulados (COLE; COWLING 2008).

De fato, identifica-se em carcinomas de mama, pele, pâncreas e linfomas uma dependência da ativação de uma série de fenômenos regidos pelo oncogene c-myc (KAPOSINOVAK et al., 2009).

Um estudo recente sobre o papel do c-myc na hepatocarcinogênese, que observou aumento da expressão de genes ativados pelo c-myc em lesões macrodissecadas, atribui a esse proto-oncogene um papel central na evolução e malignidade de LPN hepáticas e sugere até mesmo que o aumento da expressão hepática dos genes por ele regulados poderia ser considerado um biomarcador na distinção entre lesões displásicas e o carcinoma propriamente dito, podendo, inclusive ser utilizado no diagnóstico precoce do câncer (KAPOSI-NOVAK et al., 2009).

Achados de estudos recentes como o de Kaposi-Novak e colaboradores (2009) identificam o c-myc como um mediador central da carcinogênese hepática e possivelmente apresentando um papel universal na tumorigênese por atuar na manutenção e expansão de células transformadas. 
Assim, especificamente durante a hepatocarcinogênese, demonstrou-se não apenas hipometilação global do DNA (SIMILE et al., 1994; CHEN et al., 2004; TRYNDYAK et al., 2006), mas também hipometilação (MORENO et al., 2002) e aumento da expressão do oncogene c-myc em etapas pré-neoplásicas iniciais (GARCEA et al., 1989; SIMILE et al.,1994) e avançadas ( PASCALE et al., 1996).

Nesse sentido, diversos estudos relataram a ocorrência de um quadro de hipometilação global no fígado em processo carcinogênico e descrevem, inclusive que a hipometilação acarreta na alteração da expressão de proto-oncogenes como o c-myc (DIZIK, et al., 1991), o que poderia ser considerado indicativo de pior prognóstico (SHEN et al., 1998).

\subsection{Efeitos distintos do ácido fólico nas diferentes etapas da carcinogênese}

Na última década, inúmeros estudos da literatura relatam efeitos benéficos do AF no processo carcinogênico em diferentes órgãos (cólon, mama, estômago, pâncreas, pulmão, esôfago, entre outros) em animais e também em diversos estudos epidemiológicos (CANISTRO et al., 2007; KIM 2007). No entanto, meta-análises têm apresentado dificuldade em suportar as correlações inversas entre a ingestão de AF e o risco de câncer (CANISTRO et al., 2007).

Apesar dos benefícios do AF na modulação da carcinogênese, há cada vez mais indícios de que ele apresenta ações paradoxais na carcinogênese, dependente da dose e do momento de intervenção (KIM et al., 1996; SONG et al., 2000 a e b; KIM 2006b, 2007; LINDZON et al., 2009).

Assim, apesar do AF parecer consistir em um agente quimiopreventivo promissor, sua dose efetiva e o momento ideal para início do tratamento ainda não foram devidamente esclarecidos (KIM, 2006a). Alguns estudos clínicos e experimentais sugerem que a 
suplementação com AF pode aumentar o risco de desenvolvimento do câncer e acelerar a progressão tumoral, principalmente se a vitamina for administrada em concentrações elevadas ou se o tratamento for iniciado após a presença de uma LPN no órgão alvo. Dessa forma, questiona-se ainda se a suplementação com AF deve ser iniciada apenas antes do estabelecimento dos ACFs, e não após o surgimento dessas lesões (KIM, 2004; 2006a; 2006b).

Não é nova a observação do efeito promotor de tumores do AF, como pode-se constatar pela observação de que a adição de folato a tumores estabelecidos resultou em uma espécie de aceleração do fenômeno em crianças leucêmicas (FARBER et al., 1949) e, em revisão, Kim (1999) relata que outros autores também observaram o fenômeno de aceleração similar em diferentes tumores. Além disso, em 1985, Herbert também sugeriu a existência de uma associação entre a suplementação com folato e o aumento da indução de câncer em humanos.

De fato, importa esclarecer que o AF apresenta ações distintas e opostas na carcinogênese, mediadas por mecanismos específicos, conforme descrito na Figura 3. São elas:

a) em tecidos normais: a deficiência gera uma predisposição à transformação neoplásica, enquanto que a suplementação com doses modestas (4 a 10 vezes a RDA) suprime mas em doses suprafisiológicas aumenta o desenvolvimento de tumores, e o principal mecanismo que medeia essas ações seria sua participação na via de síntese de DNA;

b) em tecidos com neoplasias estabelecidas: a deficiência tem um efeito inibitório, enquanto a suplementação tem um efeito promotor na progressão das neoplasias (WARGOVICH et al., 1996; LE LEU et al., 2000b; KIM et al., 2003; KIM 2004, 2006b, 2007; LINDZON et al., 2009). 
No entanto ainda são contraditórias e até mesmo desconhecidas as ações do AF na progressão dos precursores iniciais de LPN para LPN em estágios mais avançados e câncer (KIM 2006b, 2007; LINDZON et al., 2009) (Figura 3).

\section{Ações distintas e opostas do ácido fólico na carcinogênese}

Mecanismos promotores da carcinogênese:

-danos do DNA

-reparo inadequado do DNA

-aumento da mutagênese

-hipometilação genômica

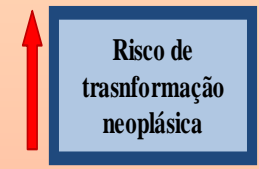

Risco de

mação

eoplásica
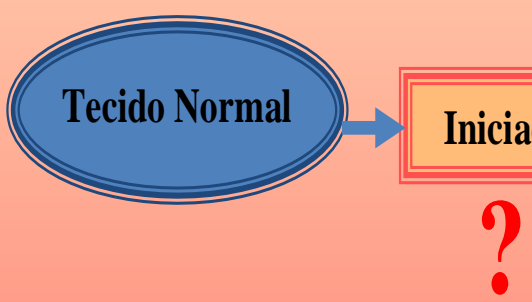

Risco de trasnformação neoplásica

$\begin{array}{cc}1 & \text { Progressão das } \\ 1 & \text { LPN }\end{array}$

Mecanismos inibitórios da carcinogênese: -integridade e estabilidade do DNA -reparo adequado do DNA -diminuição da mutagênese -contribuição para metilação adequada do DNA

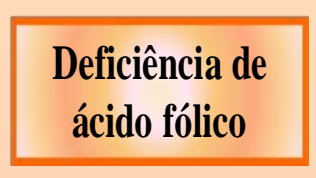

Mecanismos inibitórios da carcinogênese:

-síntese inefetiva do DNA, inibindo o crescimento do tumor

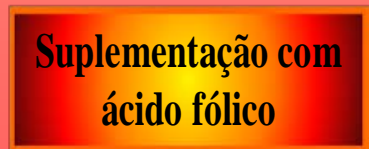

Em geral, devido às exposições ambientais ao longo da vida, há uma grande parte da população que pode ser considerada iniciada

Figura 3- Ações distintas e opostas da deficiência e da suplementação com ácido fólico nas diferentes etapas da carcinogênese. As setas vermelhas indicam ação do AF no sentido de promover a carcinogênese e as azul marinho no sentido de inibir esse processo. Adaptado de Kim (2007). 


\subsection{1 Ácido fólico e a carcinogênese coloretal}

Com relação ao potencial do AF como agente quimiopreventivo, alguns estudos avaliaram in vivo o efeito de sua suplementação tanto em animais de experimentação submetidos a modelos de carcinogênese quanto em seres humanos com câncer e, de modo geral, observa-se um forte aporte da literatura quanto à associação inversa entre o status de folato e o risco de desenvolvimento de câncer, principalmente o coloretal (KIM, 2004; 2007).

Destaca-se, em revisão, que uma ingestão adequada de folato diminui, enquanto que a depleção aumenta o risco de câncer coloretal (BOLLHEIMER et al., 2005). No entanto, esses estudos indicam que a dose e o momento de início do tratamento parecem ser críticos para o estabelecimento de efeitos quimiopreventivos (KIM, 2003; 2004; 2007).

Nesse sentido, estudos utilizando o modelo de carcinogênese de cólon induzido pela dimetilhidrazina (1,2-DMH), evidenciaram que a suplementação com AF (8 mg/Kg de ração), 4 vezes a recomendação nutricional (2 mg / Kg de ração - REEVES et al., 1993) antes da iniciação, retardou a progressão de lesões microscópicas para tumores macroscópicos. Já a suplementação com AF em doses maiores do que 4 vezes a recomendação, não implicou em qualquer efeito benéfico sendo que, na verdade, houve uma potencialização da carcinogênese de cólon em ratos suplementados com 20 vezes a RDA (KIM et al., 1996).

Outros autores descreveram que a utilização de doses altas de AF também implicou no aumento do processo carcinogênico colônico (BIRD, 1995; REDDY et al., 1996).

A suplementação com AF na ração com dose cerca de 1000 vezes a RDA em ratos iniciados com azoximetano (AOM, um metabólito da DMH) resultou em um aumento no número de ACF em comparação ao grupo controle (2 mg / Kg de ração) (BIRD, 1995). 
Além disso, dentre diversas substâncias potencialmente quimiopreventivas testadas, o AF na dose de 1250 vezes a RDA teve uma ação promotora sobre a formação de criptas aberrantes (ACFs) na fase de iniciação do câncer coloretal em ratos (WARGOVICH et al., 1996).

Posteriormente, utilizando-se uma linhagem de camundongos que desenvolvem cânceres intestinais (camundongos $A p c+/-M s h 2$-/-), observou-se que ao ser comparada ao grupo com restrição moderada de AF, a suplementação com essa vitamina (4 vezes a RDA) antes do estabelecimento de focos neoplásticos, reduziu significantemente o número ACFs, adenomas intestinais e colônicos (SONG et al., 2000b).

Song et al., (2000a) também trataram camundongos que desenvolvem espontaneamente câncer de intestino delgado e cólon (camundongos Min; do inglês Multiple Intestinal Neoplasia) durante 3 ou 6 meses com diferentes doses de AF (0, 2, 8 ou 20 mg / Kg de ração). Assim, nos animais tratados durante 3 meses, os autores observaram uma redução $(\mathrm{p}<0,05)$ de forma dose - dependente do número de ACFs e de pólipos ileais, mas não duodenais ou jejunais. Por outro lado, observaram que a suplementação com o AF, após haverem focos neoplásicos estabelecidos, parece apresentar um efeito de potencialização da carcinogênese, com aumento da ordem de quatro vezes no número de adenomas intestinais pequenos. Observaram ainda que o AF não teve efeito no desenvolvimento de focos de criptas aberrantes (ACFs) e adenomas.

O efeito promotor de tumor do AF também foi constatado em indivíduos que apresentavam adenomas coloretais previamente à suplementação, a qual promoveu um aumento de 44\% no número de adenomas (COLE et al., 2005). O mesmo grupo observou em um grande estudo envolvendo múltiplos centros, que a suplementação tendeu a promover maiores taxas de adenomas avançados e múltiplos (COLE et al., 2007). 
Mais recentemente, Van Guelpen e colaboradores (2006) observaram pela primeira vez, dentre diversos estudos epidemiológicos, um potencial efeito deletério de altas concentrações de folato no risco de câncer coloretal.

Assim, em conjunto, as informações especialmente referentes ao câncer coloretal levam a concluir que em tecidos normais a suplementação com doses excessivas de AF aumentam o desenvolvimento de câncer (WARGOVICH et al., 1996; KIM et al., 1996; LE LEU et al., 2000b) e, além disso, após a lesão neoplásica estar estabelecida, o que é comum, considerando que boa parte dos humanos estão sendo constantemente submetidos a processos de iniciação, a deficiência de AF seria mais benéfica do que a suplementação que, nesse caso, possivelmente potencializaria o fenômeno (Figura 3) (KIM 2004, 2007; BOLLHEIMER et al., 2005 ).

De fato, novos estudos também associaram altas concentrações de folato plasmático com aumento de risco de câncer coloretal (VAN GUELPEN et al., 2006) e verificaram que a suplementação com 2,5 vezes a RDA por 6 anos aumentou em aproximadamente $70 \%$ a recorrência de adenomas coloretais (COLE et al., 2007) e duplicou o risco de câncer de próstata após 10 anos de acompanhamento (FIGUEIREDO et al., 2009), confirmando o potencial efeito promotor de altas concentrações de AF.

Um estudo mais recente, conduzido por Lindzon e col. (2009), na etapa de progressão de ACFs, utilizou doses que os autores consideraram representativas dos níveis de folato ingeridos na América do Norte no período pós-fortificação e observou que mesmo essas doses moderadas (2,5 e 4 vezes a RDA) promoveram uma progressão significativa dos ACFs e que os níveis de AF dietético estavam diretamente associados à multiplicidade e peso dos tumores. Assim, esse estudo também apresenta dados que sustentam um efeito promotor de tumor do AF suplementado em LPN colônicas pré-existentes. 
Finalmente, Lindzon e col. (2009) concluem que seus achados em conjunto com os de estudos prévios em animais e humanos sugerem que há motivo suficiente para preocupação com os efeitos deletérios da suplementação com o AF no desenvolvimento e progressão da carcinogênese coloretal.

\subsection{2 Ácido fólico e a carcinogênese mamária}

Com relação ao câncer de mama, tanto quanto se sabe, o segundo órgão onde os efeitos do AF foram mais explorados após o cólon, a natureza e magnitude da correlação inversa entre a ingestão de AF da dieta e suas concentrações plasmáticas e o risco desse câncer, conforme descrito por diferentes estudos da literatura e mais recentemente por Sie e col. (2009), não estão claramente estabelecidos.

Em estudos de câncer de mama em ratas, a deficiência de AF promoveu uma supressão (BAGGOTT et al., 1992; KOTSOPOULOS et al., 2003; CHARLES et al., 2004; KOTSOPOULOS et al., 2005) e a suplementação com 4 e 20 vezes a RDA não teve efeito sobre a tumorigênese mamária (KIM et al., 2003).

Outro estudo de câncer de mama em ratas com administração de AF na dose de 20 vezes a RDA administrado na ração durante a iniciação e promoção constatou que o AF promoveu aumento da multiplicidade e aparecimento dos tumores mais rapidamente (BAGGOTT et al., 1992)

Inclusive, estudo populacional recente identificou aumento do risco de câncer de mama da ordem de $20 \%$ em mulheres com maior consumo de AF proveniente de suplementos (de origem sintética), mas não da sua forma natural presente nos alimentos (STOLZENBERG-SOLOMON et al., 2006). 


\subsection{3 Ácido fólico na hepatocarcinogênese}

O padrão de desenvolvimento da neoplasia maligna do fígado em ratos é semelhante ao que se observa em seres humanos (BANNASCH et al., 2003; SU; BANNASCH, 2003). Dessa forma, modelos de hepatocarcinogênese química em ratos são considerados dentre os melhores para o estudo da gênese e desenvolvimento in vivo de neoplasias (GRASLKRAUPP et al., 1994; HUFF, 1993).

A hepatocarcinogênese é um processo de múltiplas etapas envolvendo acúmulo seqüencial de múltiplas alterações genéticas e epigenéticas (KAPOSI-NOVAK et al., 2009)

Dentre os vários protocolos de hepatocarcinogênese descritos, o modelo do “Hepatócito Resistente” (RH, do inglês Resistant Hepatocyte), descrito em 1976 (SOLT; FARBER, 1976) e modificado em 1987 (SEMPLE-ROBERTS et al., 1987), está bem caracterizado, e é suficiente para induzir elevada incidência de cânceres. Esse modelo tem como característica a produção de LPN e neoplásicas de forma sincronizada, possibilitando, desta forma, estudos mais detalhados, inclusive da quimioprevenção do câncer (OLIVEIRA et al., 2001).

De forma similar, encontram-se LPN (nódulos) nos estágios precoces da hepatocarcinogênese humana e as mesmas podem ser úteis para identificação de marcadores tumorais precoces, estudos de progressão do câncer e para estratégias de quimioprevenção (PÉREZ-CARREÓN et al., 2006).

O desenvolvimento do modelo de hepatocarcinogênese do RH baseou-se na hipótese, agora já bastante comprovada, de que diversos carcinogênicos químicos, como a DEN, são capazes de produzir hepatócitos resistentes e um novo fenótipo constitutivo com um padrão bioquímico altamente característico, um fenótipo resistente, durante a etapa de iniciação do processo carcinogênico, caso ocorra um ciclo de proliferação celular (FARBER; SARMA, 
1987; LACONI et al., 2000). Isso ocorre pois no processo de indução desse modelo a DEN é metabolizada por enzimas do sistema monooxigenase dependente do citocromo p450, gerando metabólitos responsáveis pelo início de efeitos tóxicos (CHIARELLO et al., 1998) como formação de ligações covalentes com importantes constituintes celulares, resultando em mutações, necrose e neoplasias (YOO; et al.,1988; TRAVIS; BELEFANT, 1992).

Tais hepatócitos resistentes podem ser rapidamente estimulados de modo a formarem proliferações focais (focos e nódulos) após breve exposição a concentrações reduzidas de alguns carcinogênicos, como o 2-acetilaminofluoreno (2-AAF), associadas a um estímulo mitogênico representado por uma hepatectomia parcial (SOLT; FARBER, 1976; LACONI et al., 2000). Verifica-se esse fenômeno, pois o 2-AAF é capaz de inibir a proliferação da maior parte dos hepatócitos normais, ou seja, dos não iniciados (sensíveis), talvez por um bloqueio na atividade da DNA polimerase, devido à formação de adutos de DNA (GOETHEM et al., 1993), mas não é capaz de inibir os poucos hepatócitos resistentes (FARBER, 1995) que apresentam, caracteristicamente, atividades das enzimas das fases I e II responsáveis pela metabolização de xenobióticos, diminuídas ou aumentadas, respectivamente (ROOMI et al., 1985).

Os focos e nódulos pré-neoplásicos apresentam alterações nas expressões de várias enzimas incluindo a adenosina trifosfatase, glicose-6-fosfatase, $\gamma$-glutamiltranspeptidase e glutationa-S-transferase, forma placentária (GST-P), que comumente são utilizadas como marcadores para suas identificações (FARBER; SARMA, 1987; BANNASCH; ZERBAN, 1990; DRAGAN et al., 1997; IMAI et al., 1997; ITO et al., 2000; ITTRICH et al., 2003).

A grande maioria dos nódulos, cerca de 95-98\%, sofre “remodelação”, um processo altamente complexo envolvendo mudanças no suprimento sanguíneo e em características bioquímicas, bem como da estrutura e arquitetura celulares, retornando ao aspecto "normal” 
anterior do fígado. Uma pequena parte (2-5\%) segue outro caminho, o da persistência. (TATEMATSU et al., 1983; FARBER; RUBIN, 1991; IMAI et al., 1997).

Justamente em nódulos persistentes de hepatócitos é que claramente se conseguiu demonstrar que estes atuam como locais de futura evolução para o câncer. Assim, nódulos persistentes são facilmente observáveis cerca de sete meses após aplicação do agente iniciante, a dietilnitrosamina (DEN). Esses nódulos persistentes demonstram seqüência progressiva de evolução celular, com a ocorrência de “nódulos em nódulos” e, finalmente, aparecimento de câncer após cerca de 10-11 meses (FARBER, 1988).

Estudos utilizando ratos submetidos ao modelo de hepatocarcinogênese do RH evidenciaram que o tratamento com SAM durante a fase de promoção reduziu a área de LPN GST-P positivas (FEO et al., 1985; PASCALE et al., 1995; SIMILE et al., 1996). Da mesma forma, o tratamento com SAM iniciado, porém, 10 semanas após a etapa de iniciação, reduziu o número e o tamanho dos nódulos hepáticos (PASCALE et al., 1995; SIMILE et al., 1996).

Em nível celular e molecular, o tratamento com SAM reduz a síntese de DNA, aumenta o número de LPN em remodelação (FEO et al., 1985; SIMILE et al., 1996), induz a apoptose (GARCEA et al., 1989) e reduz a expressão dos oncogenes previamente hipometilados c-myc, c-Ha-ras e c-Ki-ras. Assim, esses resultados sugerem que o tratamento com precursores da SAM, como o AF, possa também resultar em efeitos quimiopreventivos durante a hepatocarcinogênese (PASCALE et al., 2002).

Diferentes estudos com modelos de hepatocarcinogênese em ratos resultantes de dietas deficientes em folato e metil (deficiência em folato, colina e metionina) indicam que essa deficiência promoveu a progressão de tumores no fígado (KUO et al., 2008) e promoveu LPN com hipometilação genômica, a qual pode desregular os processos apoptóticos e de proliferação celular, favorecendo o desenvolvimento de tumores (POGRIBNY et al., 2004). 
De fato, constatou-se que a deficiência de folato provoca instabilidade genômica e aumento de danos no DNA no fígado de ratos (POGRIBNY et al., 1995).

No entanto, até o momento, tanto quanto se sabe, não existem relatos a respeito do potencial quimiopreventivo do AF em modelos de hepatocarcinogênese.

Assim, considerando o papel central do AF na síntese e metilação do DNA e que a análise de modificações moleculares ocorridas já em LPN, que representam etapas preliminares da evolução da carcinogênese a partir de células iniciadas para o câncer, pode proporcionar pistas em relação a alterações fundamentais subjacentes ao desenvolvimento da neoplasia (EMMERT-BUCK et al., 1996), hipotetiza-se que suplementação com o AF possa modular a hepatocarcinogênese, em sua etapa de promoção, por esta vitamina estar diretamente relacionada com os processos genéticos de manutenção da integridade e estabilidade do DNA e epigenéticos de reversão da hipometilação global do DNA.

Dessa forma, o presente estudo objetivou, de forma ainda não descrita na literatura, avaliar os potenciais efeitos do AF quando administrado de forma contínua especificamente durante a etapa de promoção, em ratos submetidos ao modelo de hepatocarcinogênese do RH e, para aprofundar a compreensão desses efeitos nas referidas condições experimentais, foram avaliados a proliferação celular e a apoptose em LPN e no tecido hepático ao redor das mesmas, os danos ao DNA hepático e a taxa de metilação global do DNA, bem como a expressão do proto-oncogene $c$-myc, especificamente de amostras de LPN e de tecido ao redor das mesmas obtidas por meio de procedimento de microdissecção tecidual, para se discernir adequadamente populações celulares oriundas de tecidos pré-neoplásicos daquelas provenientes de tecido hepático normal ao seu redor (MAGGIONI et al., 2000; KANAI et al., 2000). 


\section{OBJETIVOS}

\subsection{Objetivo Geral}

- Avaliar os efeitos do AF quando administrado continuamente durante a etapa de promoção inicial a ratos Wistar submetidos ao modelo de hepatocarcinogênese do RH.

\subsection{Objetivos Específicos}

Avaliar os efeitos de diferentes doses de AF em sua forma sintética (utilizada nos suplementos alimentares e na fortificação compulsória) sobre:

- $\quad$ as LPN hepáticas desenvolvidas;

- a proliferação celular hepáticas em LPN e no tecido ao redor das mesmas;

- a apoptose hepáticas em LPN e no tecido ao redor das mesmas;

- $\quad$ os danos ao DNA hepático;

- o padrão hepático de metilação global do DNA em LPN e no tecido ao redor das mesmas, obtidos por meio de microdissecção;

- a expressão hepática do proto-oncogene $c$-myc em LPN e no tecido ao redor dessas lesões, obtidos por meio de microdissecção. 


\section{MATERIAL E MÉTODOS}

\subsection{Animais}

Após a devida aprovação pela Comissão de Ética em Experimentação Animal da Faculdade de Ciências Farmacêuticas da Universidade de São Paulo (protocolo CEEA n ${ }^{0}$ 122), os ensaios biológicos foram realizados nas dependências do biotério da FCF/IQ-USP em ambiente apropriado para condução de estudos de carcinogênese, com temperatura, luz e umidade ambiental controladas.

Foram utilizados 79 ratos machos adultos, albinos, da linhagem Wistar, com pesos iniciais compreendidos entre 90 e 100 g, obtidos da colônia do biotério da Faculdade de Ciências Farmacêuticas/Instituto de Química da Universidade de São Paulo (FCF/IQ-USP).

Os animais foram mantidos em gaiolas de polipropileno (no máximo 4 ratos/gaiola) com tampas de aço inoxidável, contendo maravalha previamente esterilizada, a qual foi trocada rotineiramente em dias alternados. Os ratos receberam “ad libitum” durante todo o experimento, água destilada e ração comercial peletizada comum para roedores de laboratório NuvilabCR1 (Nuvital Nutrientes S/A, Colombo / PR, Brasil) lote 295, cuja composição segue na Tabela 1. Foram controlados diariamente a ingestão de ração dos animais por caixa e os respectivos pesos de cada animal. 
Tabela 1. Composição do alimento completo para roedores NuvilabCR1.

\begin{tabular}{lll}
\hline Umidade & (máx) & $12,5 \%$ \\
Proteína Bruta & (mín) & $22 \%$ \\
Extrato Etéreo & (mín) & $4 \%$ \\
Material Mineral & (máx) & $10 \%$ \\
Matéria Fibrosa & (máx) & $8 \%$ \\
Cálcio & (máx) & $1,4 \%$ \\
Fósforo & (mín) & $0,8 \%$ \\
\hline
\end{tabular}

Além disso, a ração contava com suplementação de todos as vitaminas, microelementos e aminoácidos recomendados pelo National Research Council e National Institute of Health dos Estados Unidos da América, entre eles, o ácido fólico com uma suplementação por quilo não inferior à 1 mg.

\subsection{Protocolo experimental e aplicação do modelo de hepatocarcinogênese do Hepatócito Resistente}

Para avaliar a eventual atividade quimiopreventiva do AF durante a promoção da hepatocarcinogênese em ratos Wistar submetidos ao modelo do RH, bem como para avaliar a proliferação celular, a apoptose, os danos ao DNA, a taxa de metilação global do DNA e do gene $c$-myc e a expressão de $c$-myc em lesões pré-neoplásicas e no tecido ao redor das mesmas obtidas por meio de microdissecção tecidual, os animais foram submetidos aos procedimentos especificados abaixo (Figura 4).

Após um período de aclimatação de 7 dias, exceção feita aos 7 animais que constituíram um grupo controle à parte, de ratos considerados “normais” (grupo Normal - N), e que não foram submetidos ao modelo de hepatocarcinogênese, mas que permaneceram nas mesmas dependências em que os outros grupos experimentais até a eutanásia, 72 animais foram submetidos ao modelo de hepatocarcinogênese do RH através da aplicação do modelo do RH adaptado para ratos Wistar conforme descrito por Moreno et al. (1991), no qual os 
animais, receberam, por via intraperitoneal, uma única dose (20 mg / 100 g de peso corpóreo) necrogênica do agente iniciante dietilnitrosamina (DEN; Sigma Chemical Co., St. Louis, Mo, USA) dissolvido em solução de $\mathrm{NaCl}$ a 0,9 \%.

Após um período de recuperação de 2 semanas, administrou-se 4 doses em dias consecutivos, por intubação gástrica, de 2-acetilaminofluoreno (2-AAF; Sigma; 2 mg / 100 g de peso corpóreo/dia) dissolvido em dimetilsufóxido e óleo de milho, visando-se a seleção dos hepatócitos iniciados. Vinte e quatro horas após a última aplicação de 2-AAF, os animais foram submetidos a um potente estímulo mitogênico, representado por uma hepatectomia parcial a 70\%, realizada de acordo com Higgins e Anderson (1931). E, para finalizar o processo de indução da hepatocarcinogênese, no segundo dia após a hepatectomia parcial, os animais receberam uma dose adicional de 2-AAF (2-AAF; Sigma; 0,75 mg / 100 g de peso corpóreo/dia).

Então, os animais foram distribuídos aleatoriamente em 4 diferentes grupos experimentais, cada um com 15 a 16 animais, como segue:

Grupo Água $\left(\mathbf{H}_{2} \mathbf{O}\right)$ : decorridos 6 dias da hepatectomia parcial, os animais deste grupo receberam por intubação gástrica o veículo utilizado para solubilizar o AF, ou seja, água Milliq ${ }^{\circledR}(0,25 \mathrm{~mL} / 100 \mathrm{~g}$ de peso corpóreo/dia), diariamente, durante 5 semanas consecutivas até o dia da eutanásia. Este grupo serviu de controle para os grupos experimentais AF16, AF32 e AF64.

Grupo Ácido Fólico 16 (AF 16): decorridos 6 dias da hepatectomia parcial, os animais deste grupo experimental receberam por intubação gástrica ácido fólico (98%, Sigma®) na dosagem de 0,16 mg / 100 g de peso corpóreo/dia, dissolvido em água Milliq ${ }^{\circledR}$ (0,25 mL / 100 g de peso corpóreo/dia), diariamente, durante 5 semanas consecutivas até a eutanásia. 
Grupo Ácido Fólico 32 (AF 32): decorridos 6 dias da hepatectomia parcial, os animais deste grupo experimental receberam por intubação gástrica ácido fólico (98 \%, Sigma®) na dosagem de 0,32 mg / 100 g de peso corpóreo/dia, dissolvido em água Milliq ${ }^{\circledR ~(0,25 ~ m L ~ / ~} 100$ g de peso corpóreo/dia), diariamente, durante 5 semanas consecutivas até a eutanásia.

Grupo Ácido Fólico 64 (AF 64): decorridos 6 dias da hepatectomia parcial, os animais deste grupo experimental receberam por intubação gástrica ácido fólico (98\%, Sigma®) na dosagem de 0,64 mg / 100 g de peso corpóreo/dia, dissolvido em água Milliq ${ }^{\circledR ~(0,25 ~ m L ~ / ~} 100$ g de peso corpóreo/dia), diariamente, durante 5 semanas consecutivas até a eutanásia.

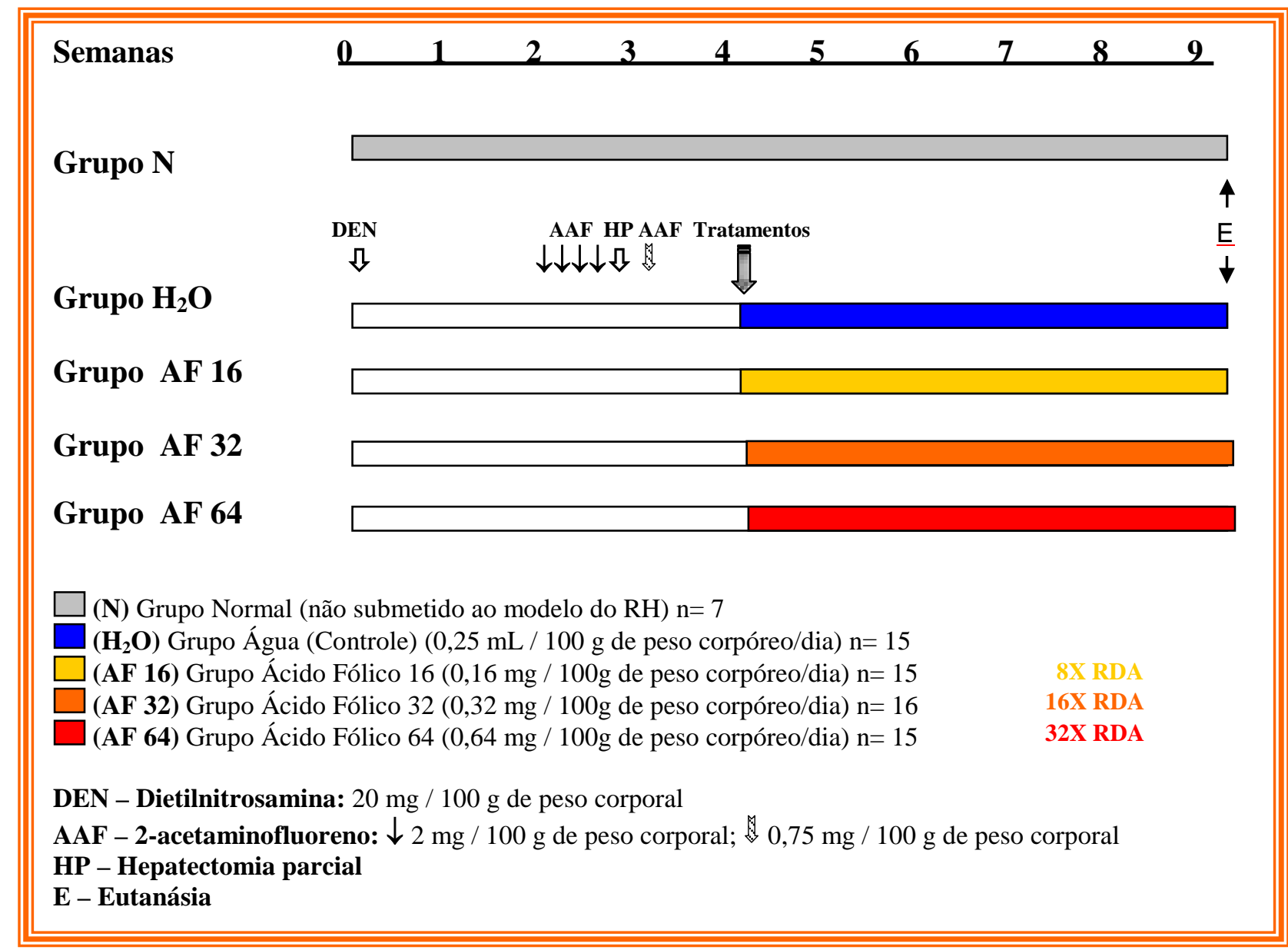

Figura 4 - Representação esquemática do protocolo experimental para avaliação das eventuais atividades quimiopreventivas do ácido fólico quando administrado por 5 semanas consecutivas durante a etapa de promoção a ratos Wistar submetidos ao modelo de hepatocarcinogênese do Hepatócito Resistente. 
As doses de AF administradas foram calculadas a partir da RDA para roedores estabelecida por REEVES et al. (1993) (2 mg de folato / Kg de dieta), com base em estudoreferência dos efeitos do AF na carcinogênese experimental onde a referida RDA foi administrada para ratos através da dieta (KIM et al., 1996). Para tanto, baseando-se em experiências prévias de nosso laboratório, estimou-se o consumo médio de ração de um rato (aproximadamente $10 \mathrm{~g} / 100 \mathrm{~g}$ de peso / dia), o que viabilizou a identificação de quanto de AF realmente os animais haviam ingerido e que a RDA de AF seria aproximadamente 0,02 mg / $100 \mathrm{~g}$ de rato.

Então, na tentativa de se modular a hepatocarcinogênese em sua fase de promoção, no presente estudo optou-se por realizar a suplementação de doses de AF constantes em relação ao peso dos animais e equivalentes a 8, 16 e 32 vezes a RDA, estabelecendo-se, respectivamente, os grupos AF 16 (0,16 mg / 100 g de peso corpóreo / dia), AF 32 (0,32 mg / 100 g de peso corpóreo / dia) e AF 64 (0,64 mg / 100 g de peso corpóreo / dia).

\subsection{Aplicação da BrDU e eutanásia dos animais}

Uma vez que se pode avaliar a replicação semi-conservativa do DNA pelo uso de um análogo estrutural da timidina, a 5-bromo-2-desoxiuridina (BrDU), que se incorpora ao DNA da célula no momento da replicação, e pode ser facilmente detectada pela coloração diferenciada das cromátides-irmãs (JUNQUEIRA; CARNEIRO, 2000), decorridas aproximadamente 6 semanas após a realização da hepatectomia parcial, os animais foram eutanasiados e, para tanto, na noite anterior à eutanásia, as rações foram retiradas e duas horas antes do mesmo, foi administrada em todos os animais, por via intraperitoneal, uma dose BrDU na concentração de 10 mg/100 g de peso corpóreo dissolvida em em solução salina 
tamponada com fosfato (PBS) $1 \mathrm{X}\left(\mathrm{KCl}, \mathrm{Na}_{2} \mathrm{HPO}_{4}, \mathrm{KH}_{2} \mathrm{PO}_{4}, \mathrm{NaCl}, \mathrm{pH} 7,4\right)$ e $\mathrm{NaOH} 1,0 \mathrm{~N}$, para posterior avaliação da proliferação celular por meio de análise imunoistoquímica.

Antes de serem eutanasiados, todos os animais foram pesados em balança eletrônica digital e, em seguida, submetidos à anestesia com éter etílico grau analítico (Merck, p.a.). Após o início da anestesia, os ratos foram colocados em decúbito dorsal sobre uma prancha, com inalação contínua de éter, procedendo-se a laparotomia. Então, a eutanásia deu-se pela secção da aorta abdominal e conseqüente choque hipovolêmico, após o que foi retirado o fígado, o qual foi "lavado" em solução salina $0,9 \%$ livre de RNAses, à temperatura de

aproximadamente $4^{\circ} \mathrm{C}$, e pesado em balança eletrônica digital, seguindo-se, então, o exame macroscópico do mesmo.

\subsection{Exame macroscópico}

O fígado de cada animal foi examinado individualmente quanto à presença em sua superfície de formações nodulares de tamanhos variados e coloração em geral esbranquiçada ou amarelada (lesões pré-neoplásicas) (BANNASCH; ZERBAN, 1990), que se distinguirem do parênquima hepático e foram classificadas pelo seu diâmetro em “< 1 mm” ou “> 1 mm”.

Posteriormente, foram colhidas de cada animal, amostras de cada lobo de fígado para análises microscópicas. Estes fragmentos de fígado foram imediatamente fixados em metacarn (60\% metanol, 30\% clorofórmio e 10\% ácido acético glacial) por aproximadamente 24 horas.

Além disso, foram ainda colhidos fragmentos do fígado para posterior avaliação de danos no DNA celular e para realização de procedimento de microdissecção de nódulo de hepatócitos ou de tecido hepático considerado normal ao seu redor. Tais fragmentos foram imediatamente congelados em nitrogênio líquido e, em seguida, armazenados em freezer a $-80^{\circ} \mathrm{C}$. 


\subsection{Exames microscópicos}

Para as análises microscópicas foram obtidos cortes de aproximadamente $5 \mu \mathrm{m}$ de espessura de cada lobo hepático. A seguir, estes fragmentos foram submetidos às técnicas rotineiras de desidratação, diafanização e inclusão em parafina.

\subsubsection{Imunoistoquímica para a GST-P}

Para a reação imunoistoquímica da Glutationa S transferase forma placentária (GSTP), o método utilizado foi o da avidina-biotina (HSU et al., 1981), empregando-se, para tanto, anticorpos policlonais anti-GST-P (MBL, Japão), utilizados na diluição de 1:1000, e anticorpos secundários biotinilados anti-imunoglobulinas de coelho (Dako, Dinamarca), na diluição de 1:400. Estes últimos consistem em anticorpos anti-IgG conjugados à biotina.

Cada procedimento foi intercalado por lavagem das lâminas em PBS. Os cortes histológicos dos materiais fixados em metacarn foram desparafinizados em xilol em seqüência de xilol/álcool (1:1), etanol absoluto, a 95\% e a 70\% e, finalmente, água destilada e a peroxidase endógena bloqueada incubando-se as lâminas por 30 minutos em metanol contendo 25\% de peróxido de hidrogênio a 30 volumes. Os cortes foram, então, incubados com o anticorpo primário diluído em solução de soro-albumina a 5\% (albumina bovina fração V; Sigma) em água destilada e azida sódica a 5\%, na diluição já mencionada, durante uma noite e a $4^{\circ} \mathrm{C}$ em câmara úmida e, em seguida, incubados por 30 minutos com o anticorpo secundário biotinilado, na diluição anteriormente citada. A aplicação do conjugado avidinabiotina-peroxidase (Kit Dako, Dinamarca) diluído em PBS (1:400) decorreu por 30 minutos. Posteriormente, foi aplicada sobre os cortes uma solução substrato de peroxidase, que consistiu na mistura de peróxido de hidrogênio a 0,02\% com diaminobenzidina (3,3’- 
diaminobenzedine; Sigma) a 0,1\% em PBS, preparada imediatamente antes da utilização. Os cortes foram então lavados em PBS por 5 minutos, contracorados pela hematoxilina e eosina, desidratados e montados com resina sintética.

A leitura das lâminas foi realizada varrendo-se todas as áreas dos cortes em objetiva de 10X e as LPN (focos e nódulos de hepatócitos) marcadas com GST-P foram quantificadas, tiveram sua área medida em $\mathrm{mm}^{2}$ e foram classificadas em LPN persistentes (com bordas definidas e coloração homogênea) ou em remodelação (com bordas irregulares e coloração heterogênea no interior do foco), utilizando-se o microscópio Axio Star Plus (Carl Zeiss, Alemanha) acoplado a sistema de análise de imagens Axio Vision (Carl Zeiss).

\subsubsection{Dupla marcação imunoistoquímica para a GST-P e BrDU}

Para realizar-se a avaliação da proliferação celular em cortes histológicos dos fígados dos ratos submetidos aos protocolos experimentais especificamente em lesões pré-neoplásicas persistentes ou em remodelação ou o tecido ao redor dessas lesões, foi utilizado o "kit” de dupla marcação imunoistoquímica (Dako Double-Stain System) (KUROIWA-TRZMIELINA et al., 2009), após a desparafinização (conforme ítem 3.5.1), exposição à HCl 2N por uma hora para abertura das fitas de DNA viabilizando o acesso do anticorpo primário às BrDUs (análogas à timina) incorporadas ao DNA da célula no momento da replicação e bloqueio da peroxidase endógena (conforme ítem 3.5.1). Os cortes foram, então, incubados com o anticorpo primário monoclonal anti-BrDU (1:400) diluído em água por 30 minutos, em seguida incubouse por mais 30 minutos com o respectivo anticorpo secundário, que constituiu em um polímero fornecido pelo Kit e a coloração com a diaminobenzidina (DAB) o seu substrato cromógeno.

Após, realizou-se o bloqueio da fosfatase alcalina através da imersão em água a $70^{\circ}$ por 20 minutos e, visando-se a marcação das LPN persistentes ou em remodelação aplicou-se o 
segundo anticorpo primário, o anticorpo policlonal anti GST-P (1:500) diluído em solução de soro-albumina a 5\% (albumina bovina fração V; Sigma) em água destilada por 30 minutos, em seguida seguiu-se para a incubação por mais 30 minutos com o respectivo anticorpo secundário, que constituiu em um segundo polímero fornecido pelo Kit e a coloração como o Fast Red, seu substrato cromógeno.

Os cortes foram então contra-corados pela hematoxilina, mergulhados 10 vezes em solução de hidróxido de amônio 37 mM objetivando virar o pH da hematoxilina, lavados em água, desidratados e montados com resina sintética.

Após a montagem das lâminas, as mesmas foram lidas em microscópio Axio Star Plus (Carl Zeiss) acoplado a sistema de análise de imagens Axio Vision (Carl Zeiss). A leitura das lâminas foi realizada varrendo-se todas as áreas dos cortes em objetiva de 40X, e o resultado foi expresso como número de células em divisão/mm² de área de LPN persistente ou em remodelação ou área de tecido ao redor das mesmas considerado normal (“surrounding”).

\subsubsection{Análise da apoptose}

Para a análise da apoptose, cortes histológicos previamente marcados para GST-P foram analisados em microscópio de fluorescência através de um método baseado na observação de que corpúsculos apoptóticos apresentam intensa fluorescência da eosina (diante da coloração com H\&E) em cortes histológicos de fígado de ratos Wistar com LPN hepáticas induzidas pela DEN (STINCHCOMBE et al.,1995).

De acordo com os autores, essa intensa fluorescência dos corpúsculos apoptóticos permite que estes sejam identificados mais rapidamente por microscopia de fluorescência em comparação com o uso de luz transmitida normal. Além disso, o uso dessa metodologia específica permite também localizar pequenos corpúsculos apoptóticos que, normalmente, não 
seriam identificados utilizando-se luz normal. Esse fato, segundo os autores, torna o método em questão cerca de 3 vezes mais sensível do que o convencionalmente utilizado e que emprega luz transmitida normal. E, em caso de dúvida a respeito da identidade da estrutura fluorescente, esta pode ser confirmada por critérios morfológicos clássicos, ou seja, corpúsculos acidofílicos arredondados de coloração rósea, que se encontram separados das células ao redor podendo, ainda, apresentar núcleo fragmentado (GRASSL-KRAUPP et al., 1994), alternando-se o sistema para luz normal. Vale ressaltar que essa metodologia foi também utilizada especificamente no modelo de hepatocarcinogênese do "Hepatócito Resistente” (WOOD; SARMA, 1999; ONG et al., 2006; MAZZANTINI et al., 2008).

Nas condições experimentais do presente trabalho, essa metodologia pode ser aplicada de modo relativamente simples, utilizando-se o microscópio Axio Star Plus (Carl Zeiss) com sistema de epifluorescência (modelo HBO 50/AC) acoplado (Carl Zeiss) e mostrou-se adequada para se determinar o número de corpúsculos apoptóticos em lesões pré-neoplásicas hepáticas e no "surrounding”.

A área total dos cortes histológicos corados com hematoxilina e eosina (H\&E) foi analisada utilizando-se objetiva de $40 \mathrm{X}$ e na medida em que se localizou os corpúsculos fluorescentes, alternou-se o sistema para luz transmitida normal e suas identidades foram, então, confirmadas de acordo com critérios morfológicos clássicos e os resultados expressos como o número de corpúsculos apoptóticos $/ \mathrm{mm}^{2}$ de área de LPN ou “surrounding”.

\subsection{Avaliação de danos ao DNA}

A análise de danos no DNA hepático, em amostras hepáticas previamente armazenadas a $-80^{\circ} \mathrm{C}$ foi realizada utilizando-se o método do "cometa”, em sua versão alcalina, conforme descrito por Espíndola et al. (2005). Essa técnica é conhecida como 
técnica do "Cometa”, uma vez que as fitas de DNA que migraram para fora do núcleo, quando vistas ao microscópio, lembram a “cauda” de um “cometa”. A distância entre a “cabeça” (núcleo) e a extremidade da "cauda” do cometa apresenta uma relação com a intensidade de quebra do DNA da célula (OLIVE et al., 1990).

Para tanto, inicialmente, os tecidos hepáticos foram homogeneizados delicadamente em $500 \mu \mathrm{L}$ de PBS sob refrigeração em gelo e ao abrigo da luz, após uma alíquota de $20 \mu \mathrm{L}$ da suspensão de células foram transferidos para um tubo de ensaio, ao qual foram adicionados 100 $\mu \mathrm{L}$ de solução de agarose de baixo ponto de fusão a $0,8 \%$ a $40^{\circ} \mathrm{C}$. Em seguida, $120 \mu \mathrm{L}$ desta suspensão de células em solução de agarose foram transferidos para uma lâmina de microscopia previamente coberta com uma solução de agarose a $0,5 \%$, cobertos por uma lamínula, incubados 5 minutos a $4^{\circ} \mathrm{C}$ e, após a retirada da lamínula, a lâmina foi submetida aos seguintes procedimentos:

-lise das células imobilizadas por 1 hora no escuro com solução de 2,5 M NaCl, 100 mM EDTA, 10 mM Tris, , 1\% n-lauril sarcosina, $\mathrm{pH}=10,1 \%$ Triton $\mathrm{X}$ 100, 10 \% DMSO;

-lavagens: as lâminas foram submetidas a 3 lavagens de 10 minutos cada, sendo uma com PBS e duas com água bidestilada e então mantidas em cuba de eletroforese horizontal contendo o tampão de corrida (3\% NaOH 10 N e 0,1\% EDTA 1M), por 20 minutos;

-eletroforese para separação das fitas de DNA $(0,9 \mathrm{~V} / \mathrm{cm}, 300 \mathrm{~mA})$ por 20 minutos no escuro;

(tanto a etapa de lise quanto a de e eletroforese foram realizadas a $4^{\circ} \mathrm{C}$ )

-neutralização (3 lavagens de 5 minutos cada com solução de Tris 0,4M, pH 7,5) seguida de uma lavagem em água bidestilada por 1 minuto e secagem em temperatura ambiente por aproximadamente 1 hora;

-fixação com solução de $15 \%$ de ácido tricloroacético, 5\% de $\mathrm{ZnSO}_{4}$, 5\% de glicerina e água por 10 minutos, seguida de nova lavagem em água bidestilada por 1 minuto; 
-secagem em estufa com temperatura até $40^{\circ} \mathrm{C}$, por 20 minutos;

-coloração com nitrato de prata utilizando-se as soluções A e B misturadas no momento da coloração (A: $\mathrm{Na}_{2} \mathrm{CO}_{3}$ a 5\% em água ultra-pura; e B: 0,02\% de $\left(\mathrm{NH}_{4}\right)_{2} \mathrm{NO}_{3}, 0,02 \%$ de $\mathrm{AgNO}_{3}$, 0,1\% de ácido sílicotungstênico, 0,05\% de formaldeído (37\%) e água ultra-pura) por 15 minutos (CERDA et al., 1997) e lavagem em água por 1 minuto;

-finalização com imersão das lâminas em solução de ácido acético 1\% por 5 minutos e, finalmente, lavagem em água e secagem em estufa.

Neste trabalho, optou-se por corar os cometas formados com nitrato de prata ao invés de com o carcinogênico brometo de etídio, devido às vantagens do método como, por exemplo, permitir o registro permanente do experimento e verificação independente dos resultados, além de evitar problemas associados à contaminação do ambiente com o carcinogênico ou à fluorescência, tais como seu decaimento (FONSECA et al., 2005; ONG et al., 2006).

Células provenientes de tecidos hepáticos de ratos normais tratados ou não com peróxido de hidrogênio (concentração final 10\%, 5 minutos, à temperatura ambiente e sob sonicação) foram utilizadas como controles negativo e positivo da metodologia, respectivamente (TOLEDO et al., 2003). A viabilidade das células hepáticas foi determinada analisando as imagens após a eletroforese. Não foram considerados viáveis cometas com aparência de nuvem ou com cabeça muito pequena e cauda semelhante a balão (células em apoptose ou necrose). Assim, a viabilidade da suspensão de células foi considerada aceitável quando a freqüência desses cometas for inferior a 2\% (BARBISAN et al., 2003; FONSECA et al., 2005; ONG et al., 2006).

A quantificação do tamanho da cauda dos cometas feita utilizando-se a objetiva de 10X de um microscópio (Axio Star Plus, Carl Zeiss) triocular com adaptador ao qual se acopla câmera de vídeo (PixeLink, modelo PLA662), conectada a um microcomputador equipado com 
sistema de análise de imagem Axio Vision (Carl Zeiss), através do qual avaliou-se o comprimento $(\mu \mathrm{m})$ de 50 nucleóides por lâmina.

\subsection{Microdissecção de focos e nódulos de hepatócitos e de tecido hepático considerado normal ao seu redor}

Visando-se a realização de experimentos envolvendo técnicas de biologia molecular sensíveis e capazes de amplificar o DNA ou RNA extraído, considera-se indispensável a microdissecção tecidual para se discernir adequadamente populações celulares, como aquelas oriundas de tecidos pré-neoplásicos, daquelas provenientes de tecido hepático normal ao seu redor (MAGGIONI et al., 2000). Sendo assim, foram obtidos cortes de $10 \mu \mathrm{m}$ a partir de fragmentos de fígado armazenados a $-80^{\circ} \mathrm{C}$, utilizando-se, para tanto, criostato $2800 \mathrm{~N}$ (Reichert Jung, Alemanha) do Departamento de Análises Clínicas e Toxicológicas da FCFUSP, os quais foram montados em lâminas de vidro e imediatamente corados rapidamente com hematoxilina e eosina (H\&E), bem como desidratados em gradiente de álcool/xilol.

Uma vez que visava-se a realização subseqüente do procedimento de microdissecção de focos e nódulos de hepatócitos ou de tecido hepático considerado normal ao seu redor (Figura 6) para obtenção de DNA e RNA, adotou-se procedimentos atendendo aos quesitos de condições RNAse "free", o que inclui a desinfecção de superfícies utilizando-se o reagente RNAse Exterminator (BioAgency) e soluções de estoque e uso preparadas utilizando-se água previamente tratada com dietilpirocarbonato (DEPC; Sigma).

Para a microdissecção, foi utilizado um aparelho (MicroDissector modelo PPMD, Eppendorf AG) acoplado a micromanipuladores motorizados controlados por "joystick" e que possibilitam a movimentação tridimencional (TransferMan NK2, Eppendorf AG), adaptados a um microscópio invertido trinocular com platina mecânica, modelo Axiovert 40 C (Carl 
Zeiss) que se baseia na utilização de uma agulha que oscila ultrassonicamente e de uma micropipeta piezo-direcionada (Figura 5) (obtidos por meio de auxílio financeiro junto à FAPESP, processo n 04/05652-7), para a rápida microdissecção histológica e aspiração da amostra em uma só etapa.

Para isso, de acordo com as etapas descritas na Figura 6, os cortes histológicos foram inicialmente recobertos com $100 \mu \mathrm{L}$ de xilol, localizando-se, em seguida, a área de interesse a ser dissecada, que foi então circundada, e microdissecada após os devidos ajustes da freqüência e amplitude da agulha de microdissecção (de 25 a 55 kHz e de 0 a $2 \mu \mathrm{m}$ ). Então, o xilol contendo as partículas de tecido geradas foi aspirado pela micropipeta de aspiração acoplada a uma ponteira GELoader com filtro MDS (Eppendorf) que, devido a sua elasticidade característica evita lesões teciduais e, agora em seu modo de ejeção, a micropipeta transferiu a amostra para um tubo de microcentrífuga (HARSCH et al., 2001). Em seguida, o solvente foi totalmente evaporado através da exposição das amostras a um concentrador a vácuo (Concentrator plus, Eppendorf AG) [obtido por meio de auxílio financeiro pelo presente projeto FAPESP ( ${ }^{\circ}$ 2006/60726-1)], pelo período aproximado de uma hora e meia, e após, o tecido livre de resíduos foi submetido aos procedimentos de extração do DNA e RNA.

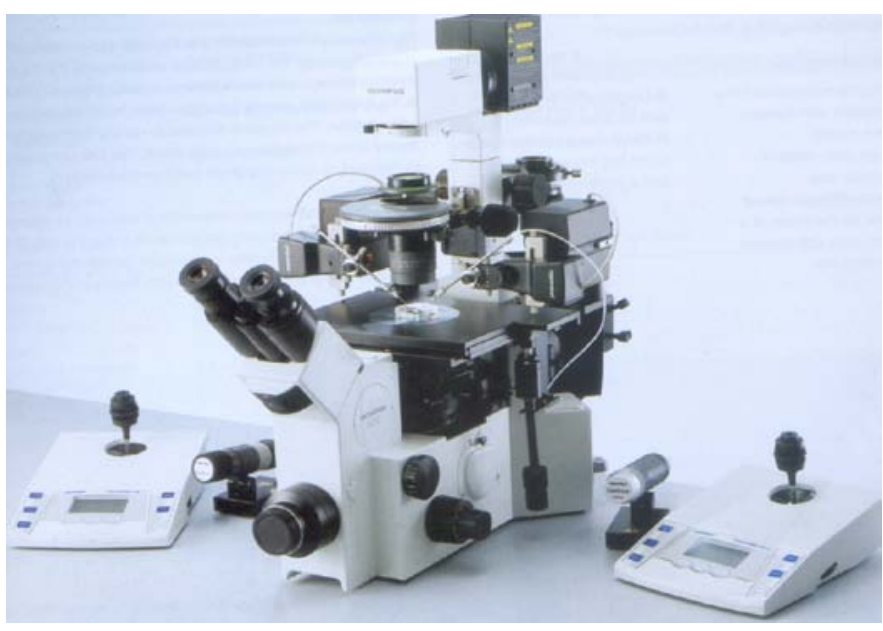

Figura 5 - Foto do equipamento de microdissecção. Por meio da utilização de uma agulha oscilante o tecido para análise é fragmentado em partículas subcelulares, que são aspiradas para o interior da micropipeta (HARSCH et al., 2001). 

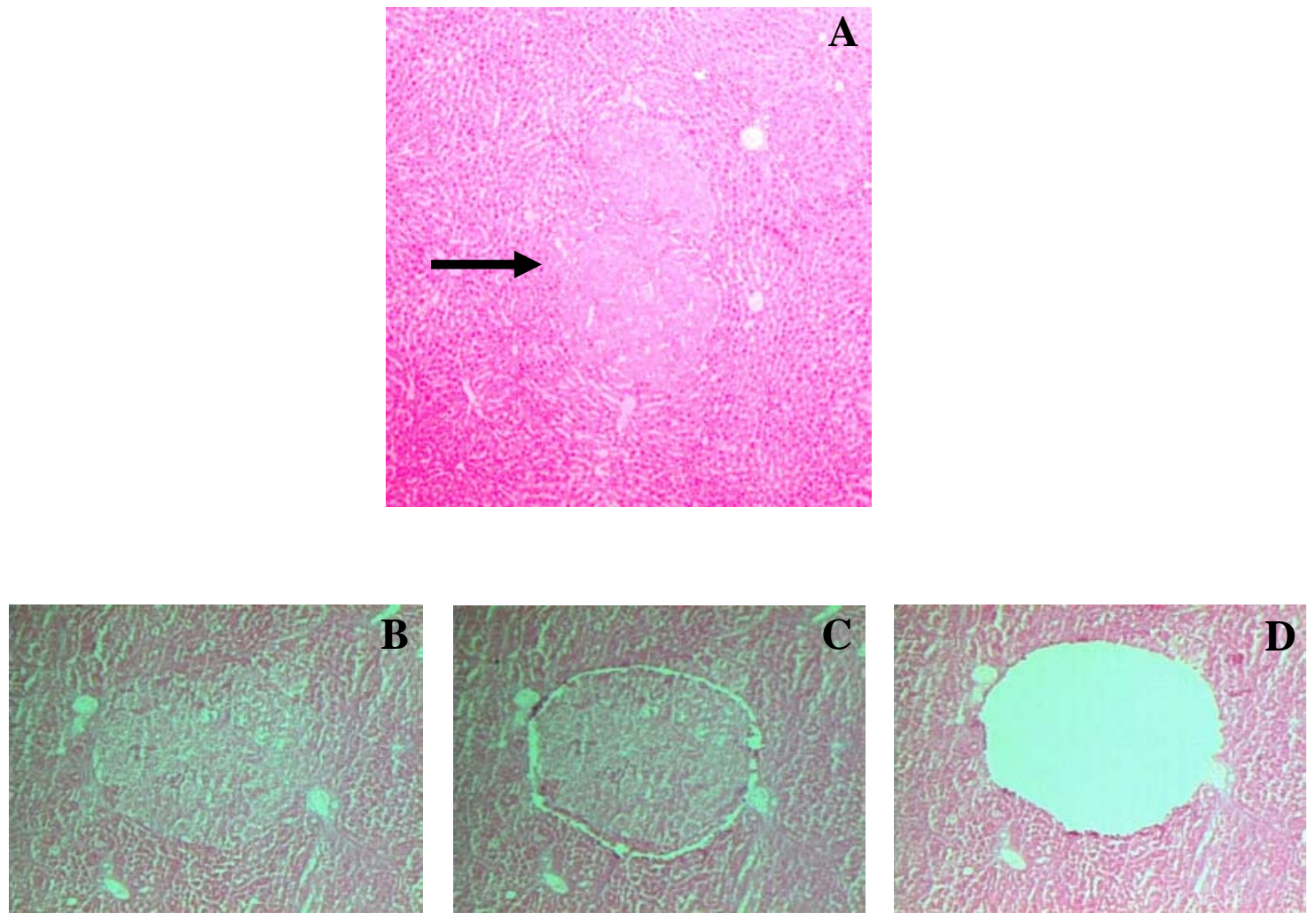

Figura 6 - Fotomicrografia de LPN hepática corada com hematoxilina e eosina (H\&E) a ser microdissecada (A) e das etapas da microdisseccão (B a D). Nas etapas da microdissecção pode-se observar uma LPN (B), o procedimento pré-microdissecção de contorno da LPN (C) e a visualização do tecido hepático microdissecado (D). Fotos obtidas com objetiva de $5 X$.

\subsection{Efeitos do AF em biomarcadores avaliados através de técnicas de biologia molecular}

Para avaliação dos efeitos do AF no padrão de metilação global do DNA e na expressão hepática do oncogene c-myc em tecido hepático total ou a partir de focos e nódulos de hepatócitos e de tecido hepático normal obtidos por microdissecção, selecionou-se de 3 a 5 animais por grupo, adotando-se o critério de proximidade à média do grupo no seguinte parâmetro de avaliação da quimioprevenção: área total de LPN positivamente marcadas pela GST-P. 


\subsubsection{Avaliação do padrão hepático de metilação global do DNA}

A técnica de "Dot Blot” (TAO et al., 2004; ALYAQOUB et al., 2006) foi utilizada para se avaliar o padrão hepático de metilação global do DNA de ratos Wistar submetidos ao modelo do RH e tratados ou não com AF. Para tanto, foram realizados os seguintes procedimentos:

\subsubsection{Extração de DNA do tecido hepático total ou a partir de focos e nódulos de hepatócitos e de tecido hepático normal obtidos por microdissecção}

A extração do DNA foi realizada utilizando-se o método do fenol/clorofórmio/isopropanol (FU et al., 2003; BAI et al., 2003), no qual, o tecido hepático total ou submetido à microdissecação das LPN e de tecido ao redor destas lesões (“surrounding”), foi submetido à digestão por uma noite à $55^{\circ} \mathrm{C}$ através da adição de $500 \mu \mathrm{L}$ de tampão de digestão com proteinase $\mathrm{K}(20 \mathrm{mg} / \mathrm{mL})$ e RNAse $(10 \mathrm{mg} / \mathrm{mL})$. A seguir, foram adicionados $500 \mu \mathrm{L}$ fenol-clorofórmio-isoamil (Invitrogen) e amostra foi incubada à temperatura ambiente por 10-15 minutos, centrifugada (956 g) por 15 minutos a $4^{\circ} \mathrm{C}$ (Centrifuge 5417R, Eppendorf AG) e o sobrenadante foi transferido para tubos Phase lock gel heavy (Eppendorf AG). Então, adicionou-se $500 \mu \mathrm{L}$ de clorofórmio/álcool isoamil (24:1) e a amostra foi submetida à agitação (10-15 minutos), centrifugação (956 g) por 15 minutos a $4^{\circ} \mathrm{C}$ e nova coleta do sobrenadante. Após a adição de solução de 4\% de acetato de sódio $3 \mathrm{M}$ em etanol absoluto, o sobrenadante foi incubado a $-80^{\circ} \mathrm{C}$ por dois dias. Finalmente, a amostra foi centifugada (15294 g) por 30 minutos a temperatura ambiente e ao "pellet" resultante devidamente seco, adicionou-se $500 \mu \mathrm{L}$ de etanol 70\%, centrifugou-se novamente (15294 g; 10 minutos) e último "pellet” obtido foi seco e eluído em TE. Após o término do procedimento de 
extração, o DNA foi incubado a $65^{\circ} \mathrm{C}$ por 30 minutos visando a desativação das DNAses. Esse método possibilitou a obtenção de DNA de qualidade, que apresentou integridade (razões na faixa de 1,9 - 2,0) e concentrações satisfatórias (até 1,5 $\mu$ g) (determinações realizadas no aparelho espectrofotomético Nanodrop ND 1000 ThermoScientific do Departamento de Análises Clínicas e Toxicológicas da FCF-USP) para serem utilizados na avaliação do padrão hepático de metilação global por Dot blot.

\subsubsection{Dot Blot}

Inicialmente, uma vez que a avaliação da metilação global foi realizada também nas LPN e no "surrounding”, ambos obtidos por microdissecção, a técnica foi padronizada a partir

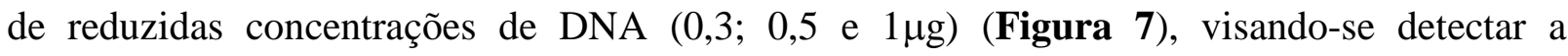
quantidade mínima de DNA necessária para se obter o resultado. O DNA nessas concentrações foi diluído em tampão SSC 10X, desnaturado com $\mathrm{NaOH} \mathrm{0,1} \mathrm{N}$ a $100^{\circ} \mathrm{C}$ durante 5 minutos, aplicado em membrana de nitrocelulose (Amersham Bioscicence), sob vácuo e submetido a subseqüente secagem e fixação em forno UV. Posteriormente, as membranas foram bloqueadas com solução de leite desnatado a 5\% em PBS com Tween 20 0,1\% (TBST) por 2 horas, e então foi aplicado o anticorpo primário monoclonal anti-5-metilcitosina (1:1000, Serotec, Reino Unido) diluído em solução de 0,5\% de leite desnatado em PBS por 2 horas. Em seguida, após 3 lavagens de 10 minutos com TBST, as membranas foram tratadas com anticorpo secundário anti IgG de camundongo (1:15000) diluído em solução de 0,5\% de leite desnatado em PBS por 1 hora . Finalmente, após mais 3 lavagens de 10 minutos com TBST, procedeu-se a revelação da membrana utilizando-se o reagente ECL (Amersham Bioscience). A intensidade do sinal foi determinada em unidades arbitrárias pelo densitômetro “Imaging Densitometer” (Modelo GS700, BIO-RAD, EUA) com “software” específico (Molecular Analyst, BIO-RAD). Para 
controle da aplicação das amostras de DNA, a membrana foi corada com azul de metileno (ALYAQOUB et al., 2006; ONG et al., 2006).

Então, constatou-se que é possível detectar um sinal de intensidade considerável até mesmo com 0,3 $\mu$ g de DNA, conforme pode-se observar na $1^{\text {a }}$ coluna (a) do Dot blot da Figura 7, viabilizando a execução da técnica com reduzidas quantidades de DNA extraídas a partir de tecido microdissecado.

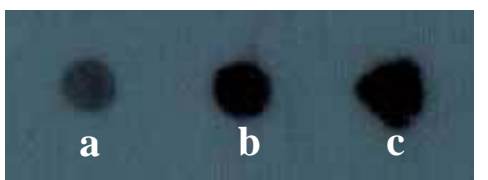

Figura 7 - Dot Blot realizado a partir de diversas concentrações de DNA genômico para a avaliação do padrão global de metilação do DNA. a) $0,3 \mu$ g de DNA; b) $0,5 \mu$ g de DNA; c) $1,0 \mu \mathrm{g}$ de DNA.

Desse modo, deu-se procedimento à avaliação do padrão hepático de metilação global em amostras de DNA de tecido hepático total $(1 \mu \mathrm{g})$ ou de LPN e de tecido ao redor destas lesões microdissecados $(0,5 \mu \mathrm{g})$.

\subsubsection{Análise da expressão hepática do proto-oncogene $c$-myc}

A técnica de RT-PCR (SIMILE et al., 2005) foi utilizada para se avaliar a expressão hepática do proto-oncogene c-myc de ratos Wistar submetidos ao modelo do RH e tratados ou não com AF. Para tanto, foram realizados os seguintes procedimentos: 


\subsubsection{Extração de RNA a partir de focos e nódulos de hepatócitos e de tecido hepático normal obtidos por microdissecção e procedimento da transcrição reversa}

A extração do RNA do tecido hepático total ou submetido à microdissecação das LPN e de tecido ao redor destas lesões (“surrounding”) foi realizada utilizando-se o Kit illustra RNAspin Mini RNA Isolation (GE Healthcare) para extração de RNA de pequenas quantidades de tecido, que tem por principais etapas a lise das células microdissecadas e simultânea inativação das RNAses, filtragem, ligação do RNA a uma membrana de sílica, digestão do DNA, lavagens com tampões que removem sais, metabólitos e componentes celulares macromoleculares e finalmente eluição do RNA purificado em água livre de RNAses em condições de reduzidas forças iônicas.

A qualidade do RNA obtido foi monitorada examinando-se a integridade das bandas $28 \mathrm{~S}$ e $18 \mathrm{~S}$ de RNAs ribossomais (tipicamente, o sinal da banda $28 \mathrm{~S}$ deve ter intensidade aproximadamente duas vezes àquela da banda 18S), em gel de agarose a $1 \%$ corado com brometo de etídeo. Além disso, averigou-se a integridade e concentração do RNA através de determinações realizadas pelo aparelho espectrofotomético Nanodrop ND 1000 ThermoScientific do Departamento de Análises Clínicas e Toxicológicas da FCF-USP e observou-se que o RNA apresentou integridade (razões na faixa de 1,8 - 2,2) e concentrações satisfatórias para ser utilizado na avaliação da expressão hepática de $c$-myc por RT-PCR.

Desse modo, prosseguiu-se à transcrição reversa a partir de reduzidas concentrações de RNA (500 ng no caso do tecido hepático total e 80 ng no caso de tecido microdissecado), utilizando-se o Kit SuperScript ${ }^{\mathrm{TM}}$ First-Strand Synthesis System for RT-PCR (Invitrogen) que tem por principal objetivo a transcrição do RNA em cDNA (mediada pela enzima SuperScript), o qual apresenta estrutura passível de amplificação pela reação em cadeia da polimerase (PCR). 


\subsubsection{RT-PCR}

A análise da expressão hepática do oncogene c-myc a partir do RNA extraído por meio de procedimento de microdissecção tecidual foi realizada por RT-PCR basicamente conforme descrito por Kim e colaboradores (2003).

Com um décimo do produto da transcrição reversa, prosseguiu-se à co-amplificação dos genes o c-myc (SIMILE et al., 2005) e GAPDH de rato (controle positivo) (LEE et al., 2001; ESTELLER et al., 2002). Cada reação de amplificação foi conduzida utilizando-se o Kit Platinum ${ }^{\circledR}$ Taq DNA Polymerase (Invitrogen), nas seguintes condições: PCR buffer $10 \mathrm{X}$ (5 $\mu \mathrm{L}), \mathrm{MgCl}_{2} 50 \mathrm{mM}(1,5 \mu \mathrm{L}), \mathrm{dNTP} \operatorname{mix} 10 \mathrm{mM}(1 \mu \mathrm{L})$, iniciador (“primer”) 5’ $10 \mu \mathrm{mol}$ (1 $\mu \mathrm{L})$; iniciador (“primer”) 3’ $10 \mu \mathrm{mol}(1 \mu \mathrm{L})$ e Taq DNA Polimerase 5 unidades / $\mu \mathrm{L}(0,4 \mu \mathrm{L})$ (Eppendorf AG). Os iniciadores (“primers”) foram os seguintes:

* Gene c-myc (422bp): 5’- CAGCTGCCAAGAGGGCCAAGTTG- 3’ (sentido)

5’- GTCAGAAGGAACCGTTCTCCTTACAC- 3’ (anti-sentido) (SIMILE et al., 2005).

* Gene GAPDH (536bp): 5’- GTTGCCATCAACGACCCCTTC- 3’ (sentido) 5’- GGATGCAGGGATGTTCTG- 3’ (anti-sentido) (LEE et al., 2001).

A temperatura específica de associação (“annealing”) de $55^{\circ} \mathrm{C}$ (SIMILE et al., 2005) foi utilizada para a avaliação simultânea da expressão dos genes em questão. Logo de início, foram testados múltiplos ciclos (tempos e temperaturas de desnaturação, associação, extensão e extensão final) em termociclador Eppendorf Mastercycler ep "S" com gradiente de temperatura 
(Eppendorf AG), no sentido de se determinar as condições ideais de PCR para cada gene. Assim, identificou-se o número de ciclos em que a amostra que apresenta maior expressão alcançou um platô de amplificação, adotando-se, a seguir, para a análise final, um número de ciclos menor do que este que foi determinado. Finalmente, procedeu-se à amplificação utilizando-se 37 ciclos de amplificação constituídos de 2 minutos e 30 segundos a $95^{\circ}$ C, 45 segundos a $55^{\circ} \mathrm{C}$ e 3 minutos a $72^{\circ} \mathrm{C}$. Os cDNAs amplificados juntamente com o marcador Blue Green (LCG) foram submetidos à eletroforese em gel de agarose a 2\%, a $80 \mathrm{~V}$ por aproximadamente uma hora e meia. Após, o gel foi exposto à luz UV e foi possível avaliar e fotografar as bandas obtidas e determinar sua intensidade por um sistema de análise de imagem baseado em densitometria utilizando-se o "Imaging Densitometer” (Modelo GS-700, BIORAD) com "software” específico (Molecular Analyst, BIO-RAD). Os sinais foram quantificados em unidades arbitrárias e os dados obtidos normalizados utilizando-se a quantificação da expressão do gene GAPDH proveniente da co-amplificação das amostras.

\subsection{Análise Estatística}

O experimento foi realizado de forma inteiramente casualizada e todos os dados obtidos foram testados quanto à distribuição normal (teste de Shapiro-Wilk) e à homogeneidade das variâncias (testes de Levene e Brown-Forsythe).

Na constatação de que foram satisfeitas as condições para aplicação dos testes estatísticos paramétricos de comparação de médias de amostras independentes, em se tratando de uma única população em estudo previamente submetida ao modelo do $\mathrm{RH}$ e posteriormente subdividida em vários grupos para os diferentes tratamentos experimentais (AG, AF 16, AF 32, e AF 64), as comparações foram realizadas pela Análise de Variância Unidimensional (One-way ANOVA) seguida do teste de Tukey. 
Para a comparação da quantificação da proliferação celular e da apoptose entre o “surrounding” e as LPN persistentes ou em remodelação do grupo $\mathrm{H}_{2} \mathrm{O}$ também aplicou-se One-way ANOVA seguida do teste de Tukey.

Para a comparação entre o número e da área das LPN GST-P positivas persistentes ou em remodelação do grupo $\mathrm{H}_{2} \mathrm{O}$ aplicou-se o teste t de Student para amostras independentes.

Nos conjuntos de dados em que não foram observadas distribuição normal e, principalmente, a homogeneidade das variâncias, os testes estatísticos não-paramétricos de Mann-Whitney ou Kruskal-Wallis foram adotados para comparação de dois ou mais grupos, respectivamente.

Na análise macroscópica das LPN, a porcentagem de nódulos menores que $1 \mathrm{~mm}$ ou maiores ou iguais a $1 \mathrm{~mm}$ foi comparada pelo teste apropriado para dados de freqüência do Qui-Quadrado.

Os resultados foram expressos como média \pm erro padrão da média ou porcentagem no caso da incidência ou classificação macroscópica das LPN e as análises estatísticas realizadas adotando-se nível de significância de 5\% (p<0,05).

\subsubsection{Análise Multivariada dos efeitos do AF nas LPN persistentes}

Em busca de uma visão global acerca dos efeitos do AF especificamente nas LPN persistentes, consideradas locais de futura evolução para o câncer, realizou-se uma Análise Multivariada dos dados, ou seja, um conjunto de análises exploratórias e estatísticas que analisam simultaneamente todos os biomarcadores avaliados: multiplicidade, número, área e \% da área do corte ocupada pelas LPN GST-P positivas persistentes, ocorrência de proliferação celular e apoptose nas LPN persistentes, padrão de metilação global do DNA e de expressão do proto-oncogene c-myc nas LPN persistentes microdissecadas. 
Para viabilizar a avaliação simultânea destes biomarcadores mesurados através de diferentes unidades, realizou-se inicialmente uma padronização dos dados, convertendo-os em desvio padronizado da média, de modo que cada biomarcador passou a apresentar média nula e variância unitária.

Então, prossegui-se para as Análises de Agrupamento (Cluster) que permitem averiguar a existência de padrões de resposta biológica promovidos pelos tratamentos com diferentes doses de AF. Para tanto, realizou-se a Análise de Agrupamento Hierárquica adotando-se o método de Ward’s e o coeficiente de dissimilaridade distância Euclidiana (quando menor a distância entre dois locais, mais similares eles são) (MARTEL et al., 2003) e também a Análise de Agrupamento Não-hieráquica (K-means).

Esse conjunto de análises possibilitou o agrupamento dos tratamentos com diferentes doses de AF e seus respectivos efeitos em subgrupos com a máxima homogeneidade entre os indivíduos no grupo e máxima heterogeneidade entre os grupos (MARTEL et al., 2003).

Após, realizou-se a Análise de Componentes Principais (PCA), que tem por característica a retenção e condensação do máximo possível da variância (variabilidade) e da informação contida nos 8 biomarcadores que avaliaram os efeitos do AF nas LPN persistentes em um número menor de componentes, de modo a viabilizar e simplificar a interpretação simultânea desses efeitos.

Nesta análise, foram considerados válidos os componentes principais (CP) que apresentaram maior capacidade de retenção de informação e consequentemente maior poder para explicar o fenômeno em estudo, que são os que apresentaram autovalores maiores do que 1,0, de acordo com critério estabelecido por Piggott \& Sharman (1986).

Finalmente, avaliou-se quais biomarcadores tiveram maior importância para a separação e caracterização dos grupos na PCA, que são os que estão mais fortemente correlacionados com o CP1, sendo que as correlações fortes (as correlações podem variar na 
faixa -1 a +1 , sendo esses dois extremos os pontos de máxima correlação) negativas caracterizam os grupos à esquerda do eixo $\mathrm{X}$ e as positivas, os à direita do eixo $\mathrm{X}$.

Todas as análises estatísticas e exploratórias foram realizadas pelo programa STATISTICA 8.0 (StatSoft). 


\section{RESULTADOS}

\subsection{Evolução do peso corpóreo}

Durante todo o ensaio os animais tiveram o peso corpóreo e a ingestão de ração controlados diariamente. De acordo com o gráfico de evolução do peso corpóreo (Figura 8), houve uma perda de peso dos animais do grupo experimental como um todo após a administração de DEN e uma relativa estabilização do peso corpóreo por ocasião da administração das 4 primeiras doses de 2-AAF, que são indícios de uma adequada aplicação do modelo de hepatocarcinogênese. Além disso, o procedimento de hepatectomia parcial (HP) apresentou numa mortalidade de 13\%, próxima à esperada na indução do modelo do RH (ONG et al., 2006; KUROIWA-TRZMIELINA et al., 2009)

De maneira geral, não houve diferença entre as curvas de peso do grupo controle (água) e dos grupos experimentais (AF 16, 32 e 64) (Figura 8), o que constitui indicativo parcial de ausência de toxicidade do AF quando administrado nessas doses durante 5 semanas consecutivas, na fase de promoção do modelo do RH. 


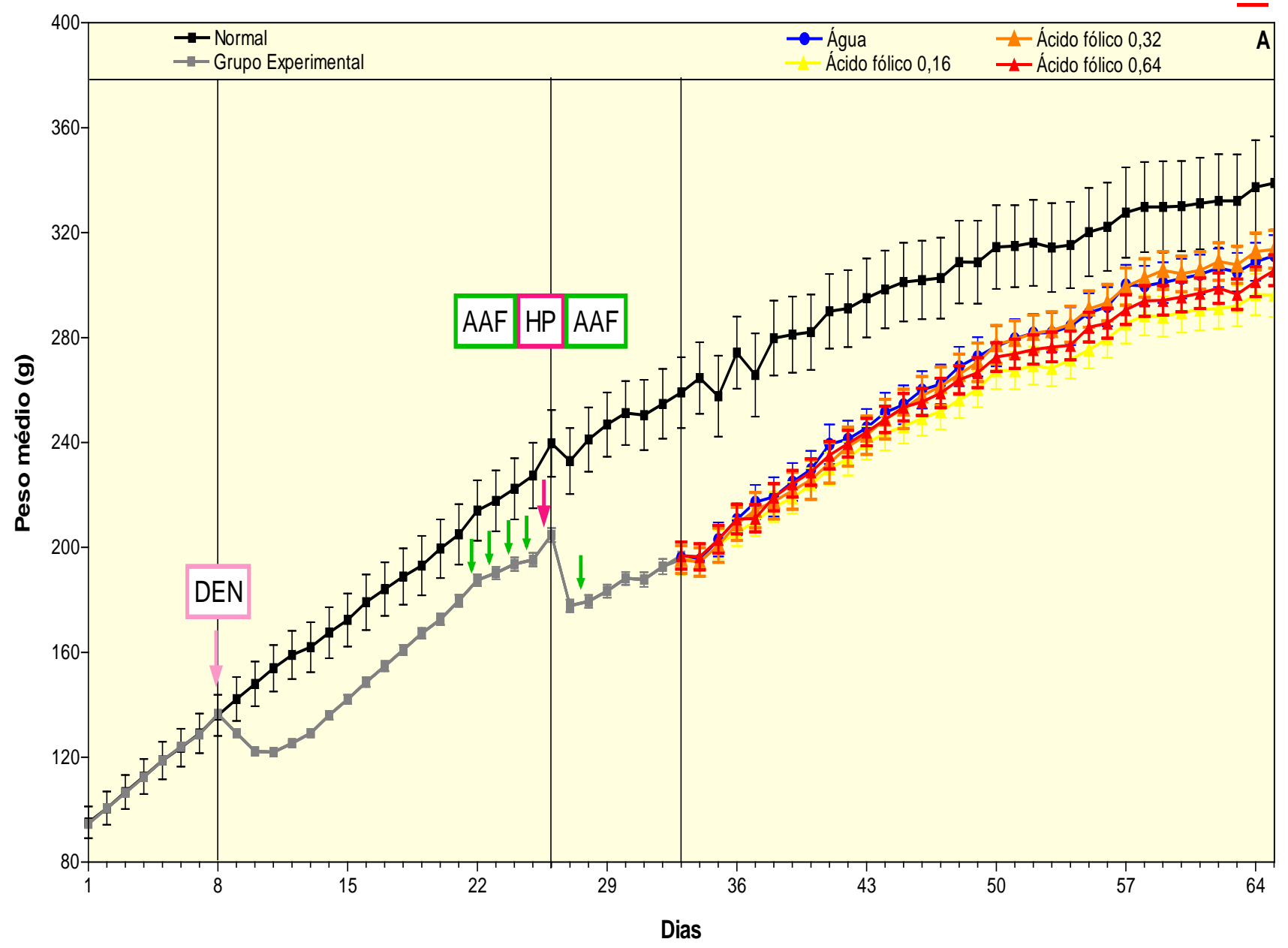

Figura 8 - Evolução do peso corpóreo dos ratos Wistar normais ou tratados com água ou ácido fólico em diferentes concentrações (0,16; 0,32; ou 0,64 mg / $100 \mathrm{~g}$ de peso corpóreo / dia ) durante 5 semanas consecutivas da promoção do modelo de hepatocarcinogênese do RH.

Neste experimento, também não foram observadas diferenças significativas no peso corpóreo final e no peso absoluto ou relativo dos fígados dos animais dos diferentes grupos experimentais $\left(\mathrm{H}_{2} \mathrm{O}, \mathrm{AF} 16, \mathrm{AF} 32\right.$ e AF64) após o período de tratamento, embora o grupo AF 32 tenha apresentado valores aparentemente maiores em todos os parâmetros acima citados (p>0,05) (Tabela 2). 
Tabela 2 - Pesos corpóreos e dos fígados de ratos normais ou tratados com água ou ácido fólico em diferentes concentrações (0,16; 0,32; ou 0,64 mg / 100 g de peso corpóreo / dia) durante 5 semanas consecutivas da promoção do modelo de hepatocarcinogênese do RH.

\begin{tabular}{lcccc}
\hline \multicolumn{1}{c}{ Grupos } & $\mathbf{n}$ & $\begin{array}{c}\text { Peso corpóreo final } \\
\text { (g) }\end{array}$ & $\begin{array}{c}\text { Peso absoluto do } \\
\text { fígado } \mathbf{( g )}\end{array}$ & $\begin{array}{c}\text { Peso relativo do fígado } \\
\text { (g/100g de peso corpóreo) }\end{array}$ \\
Normal & 7 & $338,92 \pm 17,76$ & $9,14 \pm 0,60$ & $2,78 \pm 0,07$ \\
Água & 15 & $311,17 \pm 7,90$ & $8,19 \pm 0,26$ & $2,74 \pm 0,05$ \\
Ácido Fólico 16 & 15 & $296,19 \pm 8,25$ & $7,87 \pm 0,33$ & $2,75 \pm 0,06$ \\
Ácido Fólico 32 & 16 & $313,68 \pm 7,22$ & $8,80 \pm 0,38$ & $2,96 \pm 0,11$ \\
Ácido Fólico 64 & 15 & $305,62 \pm 5,86$ & $7,84 \pm 0,27$ & $2,72 \pm 0,07$ \\
\hline
\end{tabular}

Valores expressos como média \pm erro padrão da média. Resultados analisados por ANOVA seguida de Tukey.

\subsection{Exame macroscópico dos fígados}

Os resultados da análise macroscópica do fígado permitem concluir que a incidência de LPN (Figura 9) não foi diferente entre os grupos experimentais $\left(\mathrm{H}_{2} \mathrm{O}, \mathrm{AF} 16, \mathrm{AF} 32\right.$ e AF64) (p>0,05) (Tabela 3).

No entanto, observou-se que em relação ao grupo $\mathrm{H}_{2} \mathrm{O}$, os grupos AF16 e AF32 apresentaram, respectivamente, um aumento de multiplicidade da ordem de 4 e 6 vezes, embora essas diferenças não tenham sido estatisticamente significativas $(p>0,05)$ (Tabela 3). Surpreendentemente, o grupo AF 64 apresentou uma multiplicidade muito próxima ao grupo $\mathrm{H}_{2} \mathrm{O}$, não seguindo o perfil de aumento observado com as outras duas doses de $\mathrm{AF}$ administradas (Tabela 3).

De modo similar, no que se refere à porcentagem de lesões menores ou maiores e iguais a 1, observou-se que o tratamento com o AF 0,32 mg / 100 g de peso corpóreo / dia promoveu aumento da porcentagem de lesões maiores ou iguais a 1 e o com AF 0,64 mg / 100 g de peso corpóreo / dia, de forma oposta, esteve associado a uma diminuição significativa na 
porcentagem de lesões maiores ou iguais a 1 em relação ao grupo $\mathrm{H}_{2} \mathrm{O}$ (controle) $(\mathrm{p}<0,05)$ (Tabela 3).

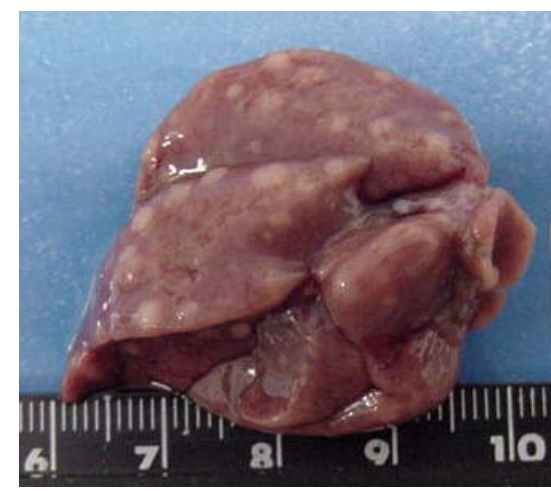

Figura 9 - Fotografia digital de fígado de rato Wistar com LPN hepáticas, em forma de nódulos de hepatócito.

Tabela 3 - Incidência, multiplicidade e \% de LPN hepáticas visíveis à macroscopia observadas por ocasião da eutanásia de ratos tratados com água ou ácido fólico em diferentes concentrações (0,16; 0,32; ou 0,64 mg / 100 g de peso corpóreo / dia) durante 5 semanas consecutivas da promoção do modelo de hepatocarcinogênese do RH.

\begin{tabular}{lccccc}
\hline Grupos & $\begin{array}{c}\text { Ratos com LPN } \\
\text { visíveis à } \\
\text { macroscopia }\end{array}$ & $\begin{array}{c}\text { Incidência de } \\
\text { LPN visiveis à } \\
\text { macroscopia (\%) }\end{array}$ & Multiplicidade & \multicolumn{2}{c}{$\begin{array}{c}\text { LPN visíveis à } \\
\text { macroscopia (\%) }\end{array}$} \\
Água & $15 / 15$ & 100 & $17,53 \pm 4,89$ & $33,84^{\mathrm{a}}$ & $66,16^{\mathrm{a}}$ \\
Ácido Fólico 16 & $14 / 15$ & 93,33 & $69 \pm 20,81$ & $37,67^{\mathrm{ab}}$ & $62,33^{\mathrm{ab}}$ \\
Ácido Fólico 32 & $16 / 16$ & 100 & $95,5 \pm 38,67$ & $19,83^{\mathrm{c}}$ & $80,17^{\mathrm{c}}$ \\
Ácido Fólico 64 & $15 / 15$ & 100 & $20,53 \pm 5,14$ & $42,86^{\mathrm{b}}$ & $57,14^{\mathrm{b}}$ \\
\hline
\end{tabular}

Valores expressos como média \pm erro padrão da média. Resultados da incidência e da porcentagem de LPN visíveis à macroscopia analisados pelo teste Qui-Quadrado. Resultados da multiplicidade analisados por Kruskal-Wallis. Médias com letras diferentes nas colunas representam diferença significativa $(\mathrm{p}<0,05)$.

\subsection{Análise morfométrica das LPN hepáticas GST-P positivas}

A análise das LPN GST-P positivas (Figura 10) do grupo $\mathrm{H}_{2} \mathrm{O}$ permitiu observar que houve a indução satisfatória do modelo do RH com uma porcentagem da área do corte 
ocupada por LPN totais (LPN persistentes + em remodelação) da ordem de 10\% (Figura 13), sendo que, no grupo controle $\left(\mathrm{H}_{2} \mathrm{O}\right)$ houve maior número de LPN em remodelação $(\mathrm{p}<0,05)$ (Figura 11), porém as LPN persistentes apresentaram maior área (Figura 12) $(p<0,05)$ e, de fato, durante as análises microscópicas encontrou-se cortes histológicos de fígado com LPN persistentes de tamanho pronunciado.

Com relação aos grupos tratados com AF, observou-se uma ação mais pronunciada das diferentes doses administradas nas LPN persistentes, não ocorrendo alterações dignas de nota nas LPN em remodelação (Figuras 11, 12 e 13).

No que se refere ao número de LPN do grupo $\mathrm{H}_{2} \mathrm{O}(27,87 \pm 4,34)$, os grupos AF 16 $(34,37 \pm 4,61)$ e $32(40,36 \pm 5,77)$ tenderam a aumentar o número das LPN persitentes, enquanto que o grupo AF 64 tendeu a diminuir $(20,02 \pm 2,88)(\mathrm{p}>0,05)$ (Figura 11).

Fenômeno similar foi observado ao se analisar a área das LPN, de modo que em relação ao grupo $\mathrm{H}_{2} \mathrm{O}(0,19 \pm 0,02)$, os grupos $\mathrm{AF} 16(0,26 \pm 0,04)$ e $32(0,32 \pm 0,07)$, tenderam a aumentar a área das LPN persistentes e o grupo AF 64 a apresentar um padrão similar ao grupo controle $(0,20 \pm 0,03)(\mathrm{p}>0,05)$ (Figura 12).

Finalmente, na porcentagem da área do corte ocupada por LPN, parâmetro que une os conceitos de número e área das LPN, pode-se confirmar o perfil de ação do AF, pois o mesmo nas doses de 0,16 e 0,32 mg / 100 g de peso corpóreo / dia duplicou (10,57 $\pm 2,40)$ e triplicou $(15,53 \pm 4,24)(p>0,05)$, respectivamente, a área do corte ocupada por LPN persistentes em relação ao grupo $\mathrm{H}_{2} \mathrm{O}(5,33 \pm 1,01)$, enquanto que a dose de 0,64 mg / $100 \mathrm{~g}$ de peso corpóreo / dia, de forma inesperada, apresentou uma área do corte ocupada por essas lesões ligeiramente menor do que o grupo controle $(4,89 \pm 1,07)(\mathrm{p}>0,05)$ (Figura 13).

Assim, embora não se tenha observado diferenças estatisticamente significantes, a análise conjunta do número (Figura 11), área (Figura 12) e porcentagem da área do corte ocupada (Figuras 13) por LPN GST-P positivas persistentes ou em remodelação permitiu 
constatar, principalmente devido ao perfil das LPN persistentes (Figura 10 A), que o tratamento com AF 0,32 mg / 100 g de peso corpóreo / dia promoveu aumento enquanto o tratamento com AF 0,64 mg / 100 g de peso corpóreo / dia inibiu o processo carcinogênico, $(\mathrm{p}>0,05)$.

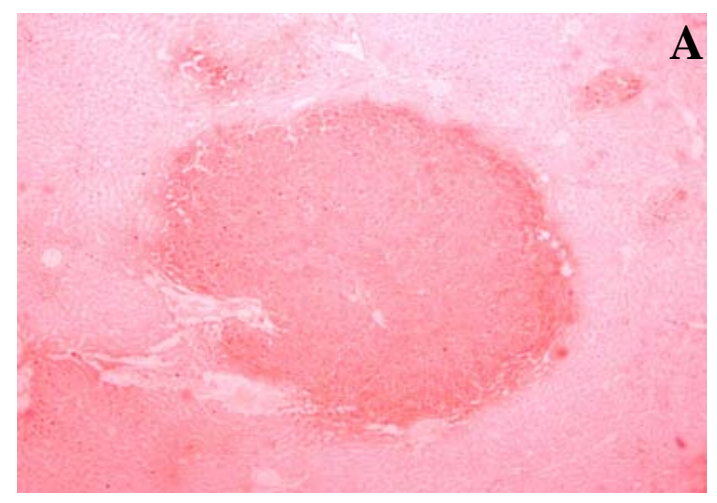

A

Figura 10 - Fotomicrografias de cortes histológicos de fígado de rato Wistar submetido ao modelo do RH com LPN GST-P positivas persistentes (A) e em remodelação (B). Nas LPN persistentes (A) observar bordas definidas e coloração homogênea e na LPN em remodelação (B), ao centro do corte, bordas irregulares e coloração heterogênea no interior do foco. Foto A e B obtidas rom objetiva de $5 X$.

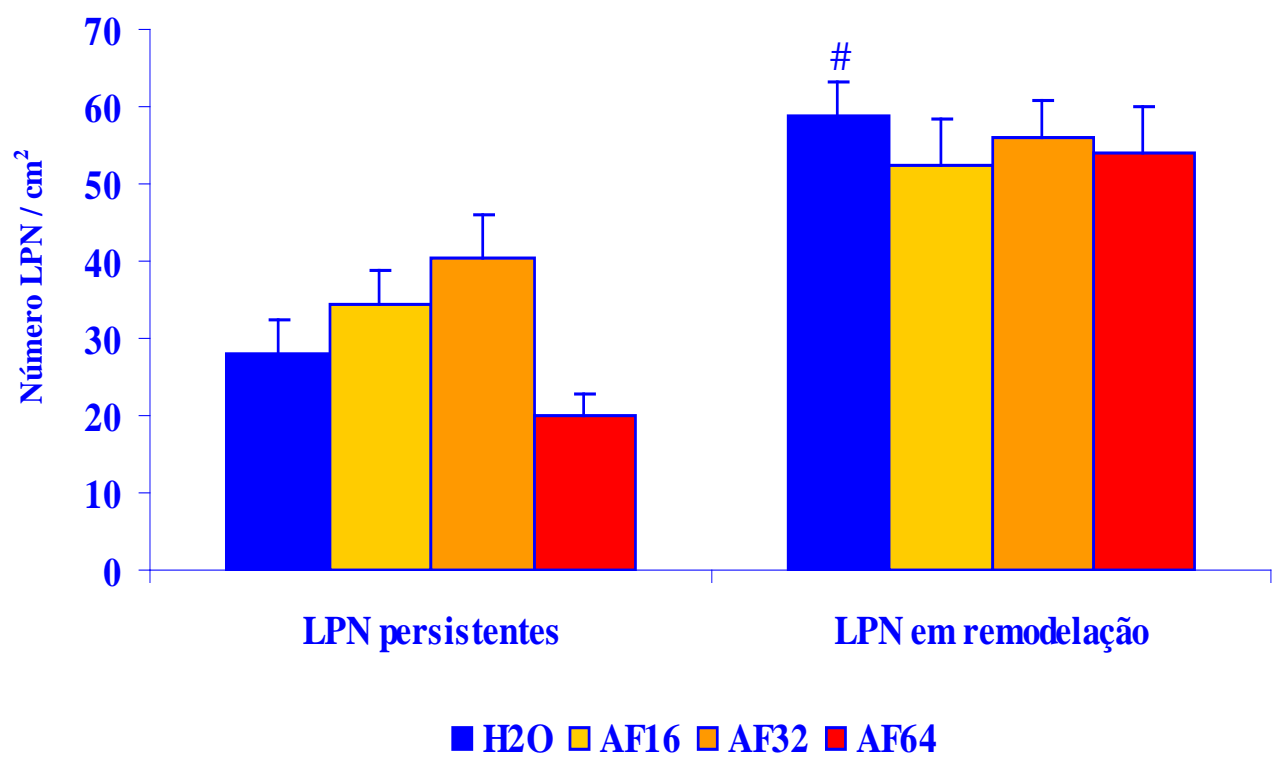

Figura 11 - Número de LPN / $\mathbf{c m}^{2}$ de corte histológico. Valores expressos como média \pm erro padrão da média (n=14-16) e analisados por ANOVA ou Kruskal-Wallis, adotando-se o nível de significância de 5\%. \# p<0,05 diferença estatisticamente significativa em relação às lesões em persistentes do grupo $\mathrm{H}_{2} \mathrm{O}$. 


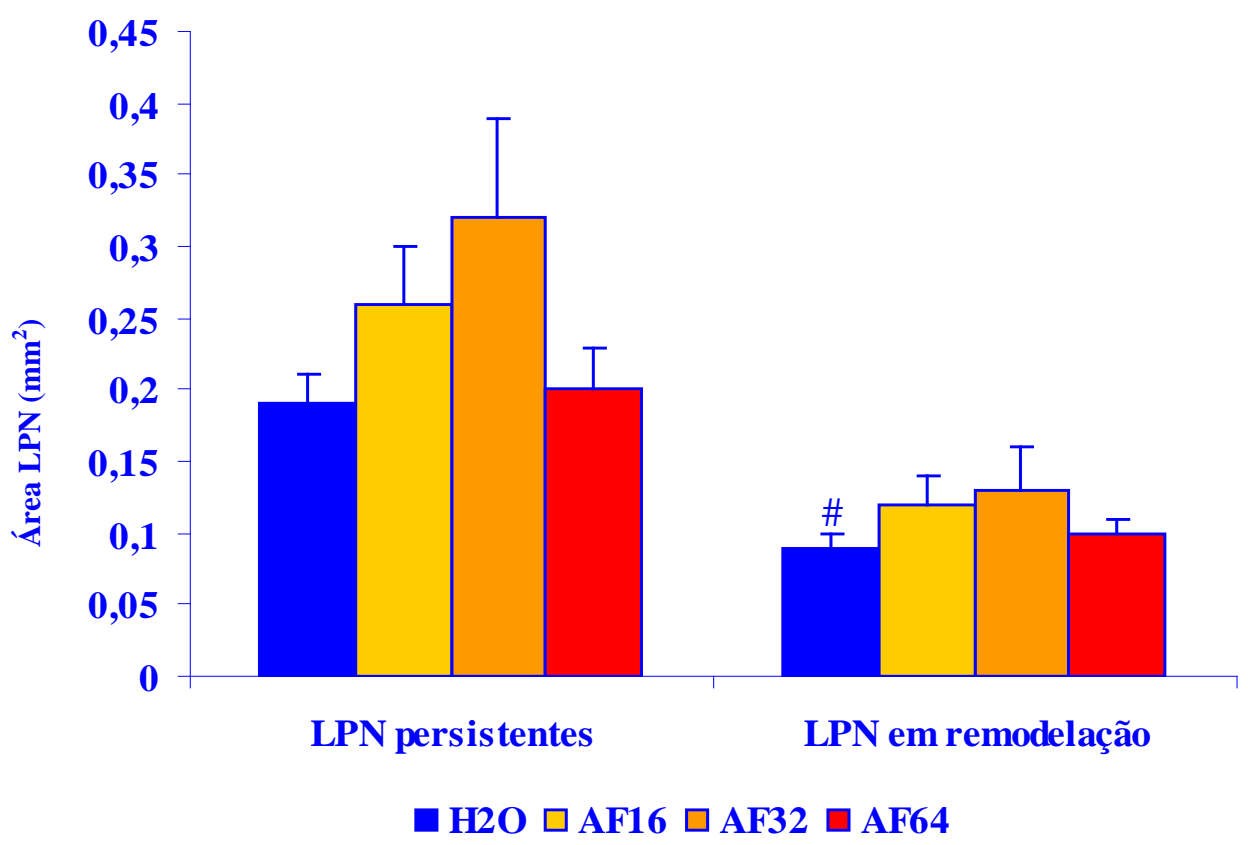

Figura 12 - Área média das LPN (mm²). Valores expressos como média \pm erro padrão da média ( $n=14-16)$ e analisados por ANOVA ou Kruskal-Wallis, adotando-se o nível de significância de $5 \%$. \# p <0,05 diferença estatisticamente significativa em relação às lesões em persistentes do grupo $\mathrm{H}_{2} \mathrm{O}$.

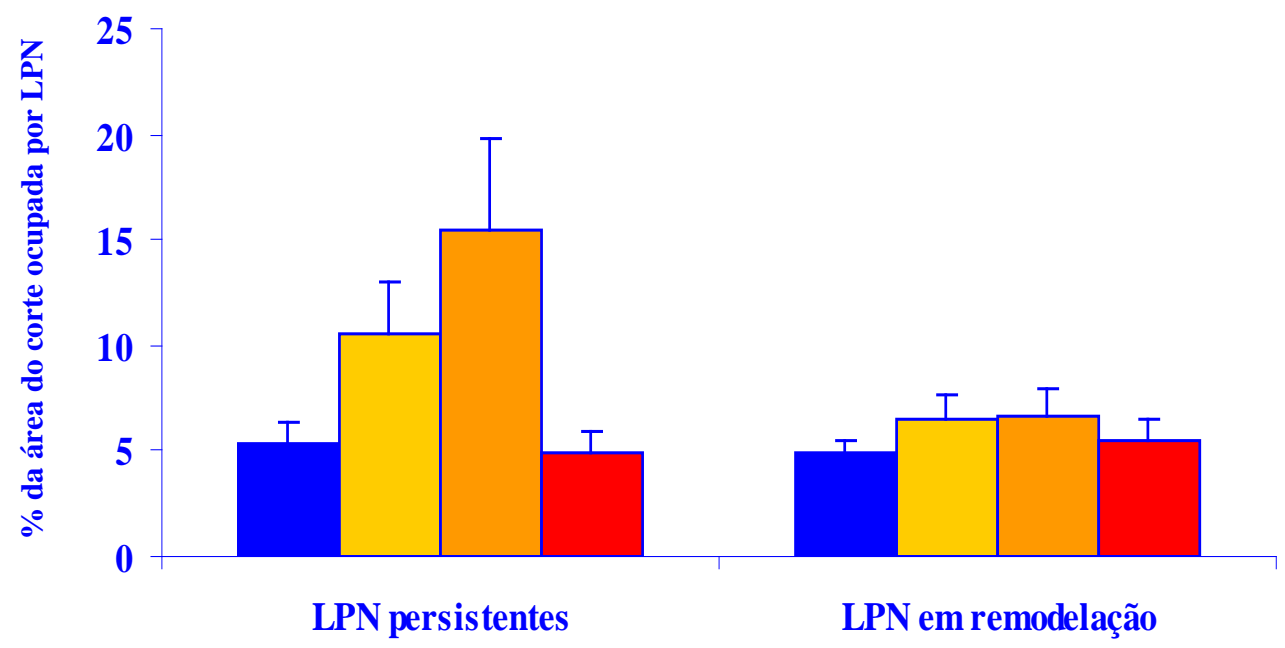

$\square \mathrm{H} 20 \square \mathrm{AF} 16 \square \mathrm{AF32} \square \mathrm{AF64}$

Figura 13 - Porcentagem da área do corte histológico ocupada por LPN. Valores expressos como média \pm erro padrão da média $(n=14-16)$ e analisados por ANOVA ou Kruskal-Wallis, adotando-se o nível de significância de 5\%. 


\subsection{Proliferação celular}

A análise do efeito do AF nas taxas de proliferação celular através da contagem do número de núcleos marcados positivamente pela 5-bromo-2-desoxiuridina (BrdU) em LPN persistentes, em remodelação ou no tecido ao seu redor (“surrounding”) (Figura 14), permitiu observar, de modo geral, maiores taxas de proliferação nas LPN persistentes (grupo $\mathrm{H}_{2} \mathrm{O}$ $=5,47 \pm 1,14)(\mathrm{p}<0,05)$ e em remodelação (grupo $\left.\mathrm{H}_{2} \mathrm{O}=3,27 \pm 0,78\right)(\mathrm{p}>0,05)$ do que no “surrounding” (grupo $\mathrm{H}_{2} \mathrm{O}=2,13 \pm 0,49$ ). Além disso, pode-se observar que a proliferação celular é maior nas LPN persistentes, do que nas em remodelação ( $p>0,05)$ (Figura 15).

Em relação ao grupo controle $\left(\mathrm{H}_{2} \mathrm{O}\right)$, o tratamento com o AF 0,16 mg / 100 g de peso corpóreo / dia não teve efeito modulador sobre as taxas de proliferação, embora tenha promovido uma tendência à diminuição da proliferação no “surrounding” $(1,28 \pm 0,22)$, LPN persistentes $(2,79 \pm 0,72)$ e em remodelação $(1,89 \pm 0,53)(\mathrm{p}>0,05)$ (Figura 15).

Por outro lado, o AF 0,32 mg / 100 g de peso corpóreo / dia tendeu a reduzir a proliferação no “surrounding” $(0,94 \pm 0,20)$ e nas LPN em remodelação $(1,06 \pm 0,24)$ e de fato, promoveu uma inibição de aproximadamente 75\% na proliferação especificamente nas LPN persistentes $(1,36 \pm 0,46)(\mathrm{p}<0,05)$ (Figura 15).

Já no grupo tratado com AF 0,64 mg / 100 g de peso corpóreo / dia, constatou-se um efeito inibitório mais pronunciado que abrangiu inibições da ordem de 70\% no "surrounding” $(0,64 \pm 0,17), 80 \%$ nas LPN persistentes $(0,95 \pm 0,28)$ e de $85 \%$ nas LPN em remodelação $(0,50 \pm 0,13)(\mathrm{p}<0,05)$ (Figura 15). 

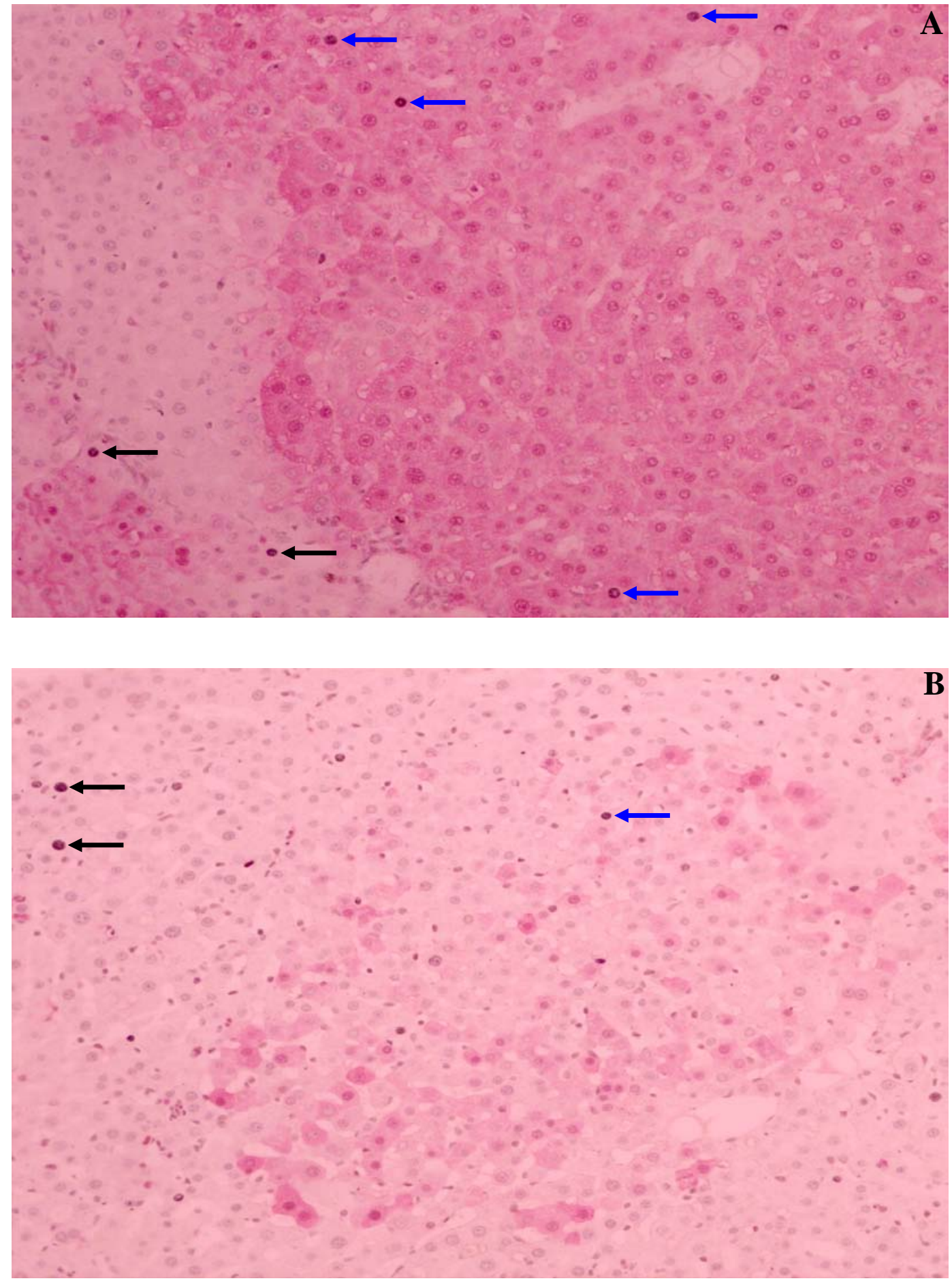

Figura 14 - Fotomicrografia de hepatócitos com núcleos marcados positivamente pela 5bromo-2-desoxiuridina (BrdU) no tecido ao redor de uma LPN e no interior de LPNs GST-P positivas persistentes (A) e em remodelação (B). Setas pretas indicam hepatócitos com núcleos marcados positivamente pela BrdU no tecido ao redor de uma LPN e setas azuis no interior de LPNs. Fotos A e B obtidas com objetiva de 20X. 


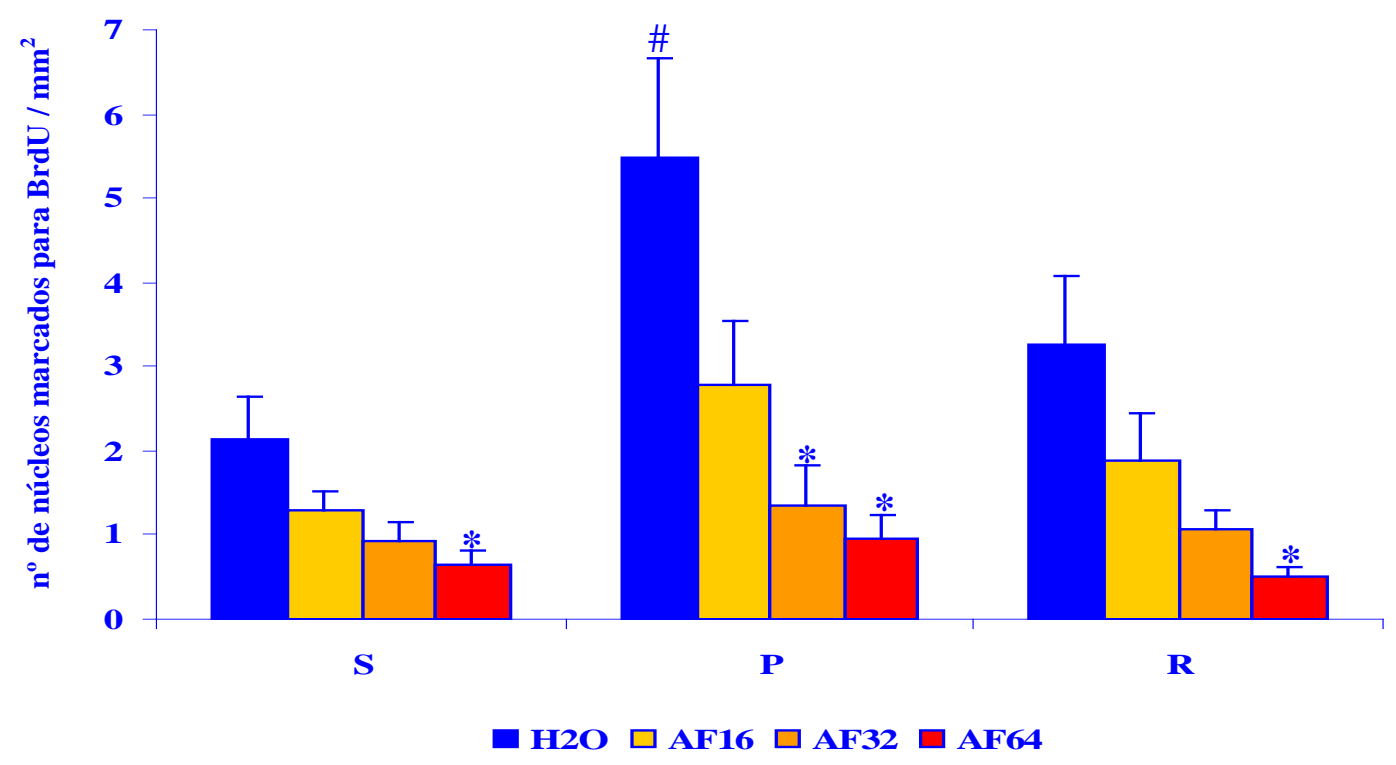

Figura 15 - Quantificação da proliferação celular hepática. S: área ao redor das LPN; P: LPN persistentes; R: LPN em remodelação. Resultados expressos como média \pm erro padrão da média (n=14-15) e analisados por Kruskal-Wallis, adotando-se o nível de significância de $5 \%$.

\# p<0,05 diferença estatisticamente significativa em relação ao surronding do grupo $\mathrm{H}_{2} \mathrm{O}$.

* $\mathrm{p}<0,05$ diferença estatisticamente significativa em relação ao grupo controle.

\subsection{Apoptose}

A avaliação da apoptose através da contagem de corpúsculos apoptóticos que fluorescem (Figura 16) em LPN persistentes, em remodelação ou no tecido ao seu redor (“surrounding”) permitiu observar que esse fenômeno apresentou uma maior ocorrência nas LPN do que no "surrounding” ( $\mathrm{p}>0,05)$ (Figura 17).

Pode-se observar que, com relação ao grupo $\mathrm{H}_{2} \mathrm{O}$, que apresentou o seguinte perfil de corpúsculos apoptóticos: LPN totais $(0,43 \pm 0,12)$, persistentes $(0,47 \pm 0,15)$ e em remodelação $(0,38 \pm 0,12)$, o grupo AF 16 promoveu uma tendência à indução da apoptose nas LPN totais $(0,47 \pm 0,15)$ e, de forma mais pronunciada nas persistentes $(0,76 \pm 0,39)$, 
com um aumento da ordem de $60 \%$ e apresentou valores muito similares aos do grupo controle nas LPN em remodelação $(0,36 \pm 0,1)$ (Figura 17).

Por outro lado, o grupo AF 32 tendeu a inibir a apoptose em relação ao grupo $\mathrm{H}_{2} \mathrm{O}$ apresentando valores aproximadamente $30 \%$ menores nas LPN totais $(0,33 \pm 0,08)$ e 3 vezes menores nas LPN em remodelação $(0,1 \pm 0,03)(p>0,05)$. Já nas LPN persistentes, o tratamento com AF nessa dose promoveu efeito similar $(0,48 \pm 0,15)$ ao observado no grupo controle (Figura 17).

Já o grupo AF 64, apresentou uma tendência ainda mais pronunciada de inibir a apoptose em relação ao grupo $\mathrm{H}_{2} \mathrm{O}$, apresentando valores 2 vezes menores nas LPN totais $(0,18 \pm 0,05)$ e também nas LPN persistentes $(0,22 \pm 0,07)$ e 3 vezes menores nas LPN em remodelação $(0,11 \pm 0,05)(\mathrm{p}>0,05)$ (Figura 17).

Assim, de modo geral, com relação aos efeitos do AF sobre esse biomarcador, observou-se uma redução, embora não estatisticamente significativa, do número de corpúsculos apoptóticos nas LPN persistentes e em remodelação com caráter dosedependente, ou seja, quanto maior a dose de AF, menor o número de corpúsculos apoptóticos observados ( $>$ >0,05) (Figura 17).
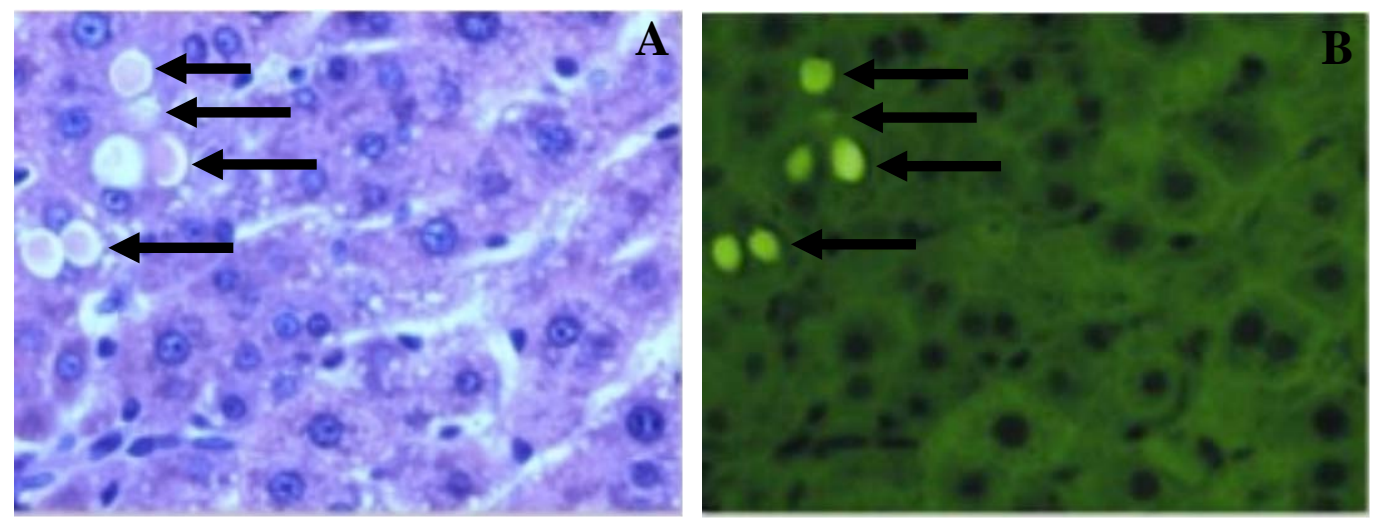

Figura 16 - Fotomicrografia de corpúsculos apoptóticos detectado em corte histológico de fígado de rato Wistar submetido ao modelo do RH e corado com hematoxilina e eosina (H\&E) em luz normal transmitida (A), e a mesma região do corte observada em microscopia de fluorescência (B). As setas indicam os corpúsculos apoptóticos. Fotos A e B obtidas com objetiva de 40X. 


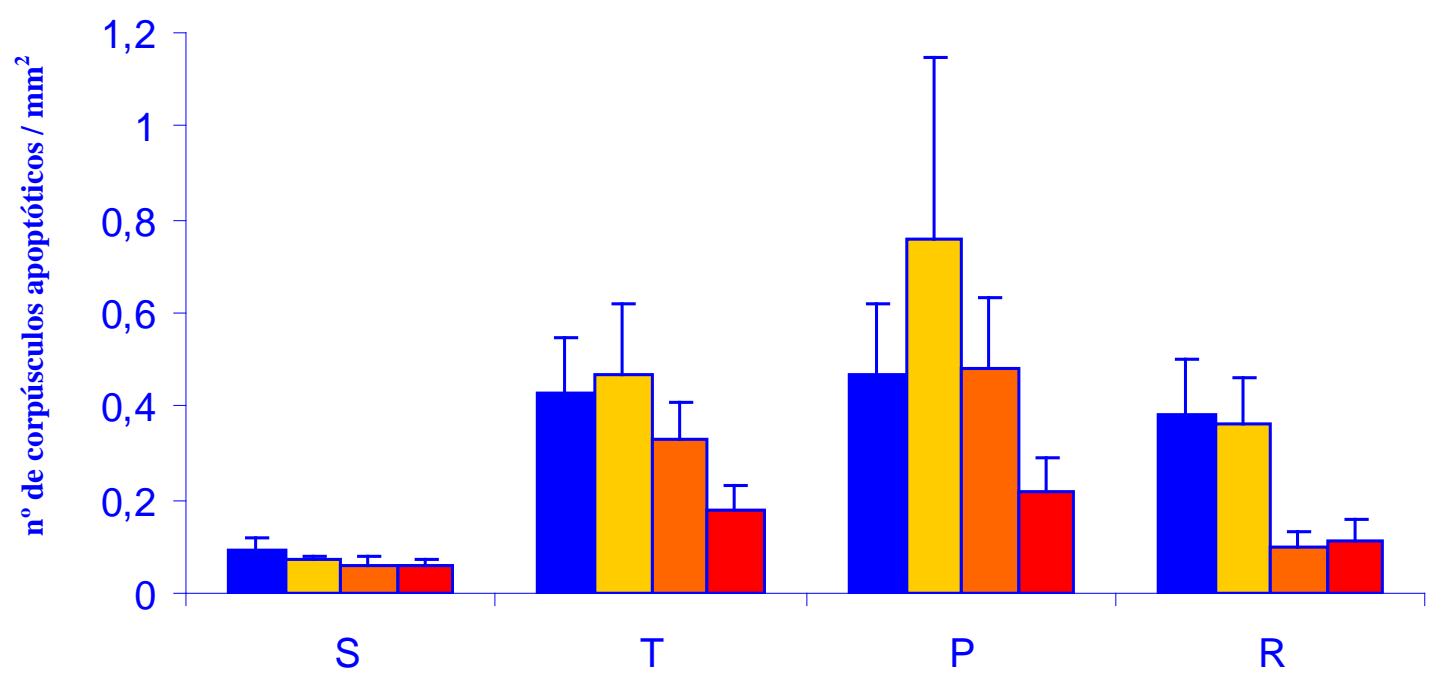

$\square \mathrm{H} 20 \square \mathrm{AF16} \square \mathrm{AF32} \square \mathrm{AF64}$

Figura 17- Quantificação de corpúsculos apoptóticos por $\mathbf{m m}^{2}$ em LPN persistentes, em remodelação e ao redor delas (“surrounding”). S: área ao redor das LPN; T: LPN totais; P: LPN persistentes; R: LPN em remodelação. Valores expressos como média \pm erro padrão da média de 1416 animais e analisados por ANOVA ou Kruskal-Wallis, quando apropriado, adotando-se o nível de significância de 5\%.

\subsection{Danos ao DNA}

A análise do comprimento dos cometas (Figura 18) permitiu observar uma maior intensidade de quebra do DNA das células hepáticas nos animais submetidos ao modelo de hepatocarcinogênese (grupo $\left.\mathrm{H}_{2} \mathrm{O}\right)(99,08 \pm 11,42)$ (Figuras 18 B e 19) do que no grupo normal $(88,89 \pm 6,94)$ (Figuras 18 A e 19), embora não se tenha observado diferenças estatisticamente significantes ( $p>0,05)$.

Uma vez que as médias dos comprimentos dos cometas dos grupos tratados com AF $16(97,95 \pm 8,91), 32(90,24 \pm 8,01)$ e $64(85,34 \pm 7,41)$ foram muito similares à do grupo controle $\left(\mathrm{H}_{2} \mathrm{O}\right)$, aparentemente, o tratamento com AF, mesmo em diferentes doses, não teve ação moduladora sobre os danos ao DNA hepático na etapa de promoção desse modelo de carcinogênese ( $>>0,05)$ (Figura 19). 
Apesar disso, observou-se que o tratamento que apresentou o menor valor $(85,34 \pm 7,41)$, inclusive aproximando-se do grupo normal $(88,89 \pm 6,94)$, foi o com o AF 0,64 mg / 100 g de peso corpóreo / dia (Figura 19).

A

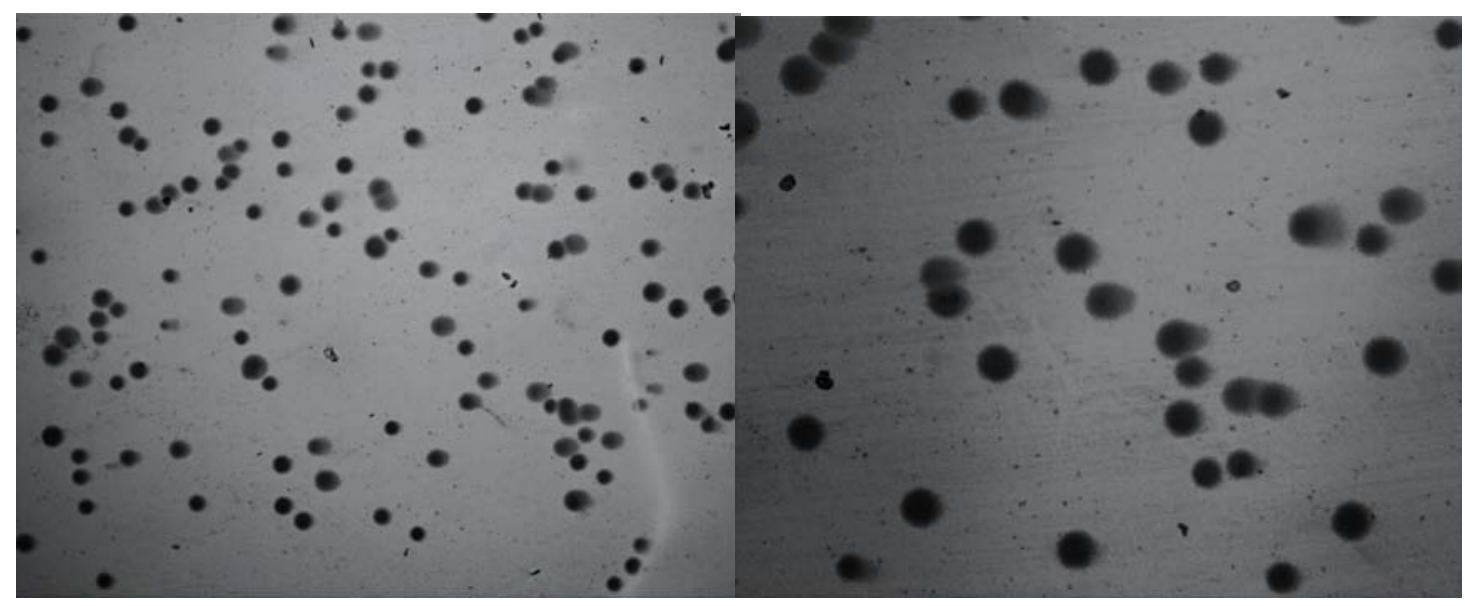

B

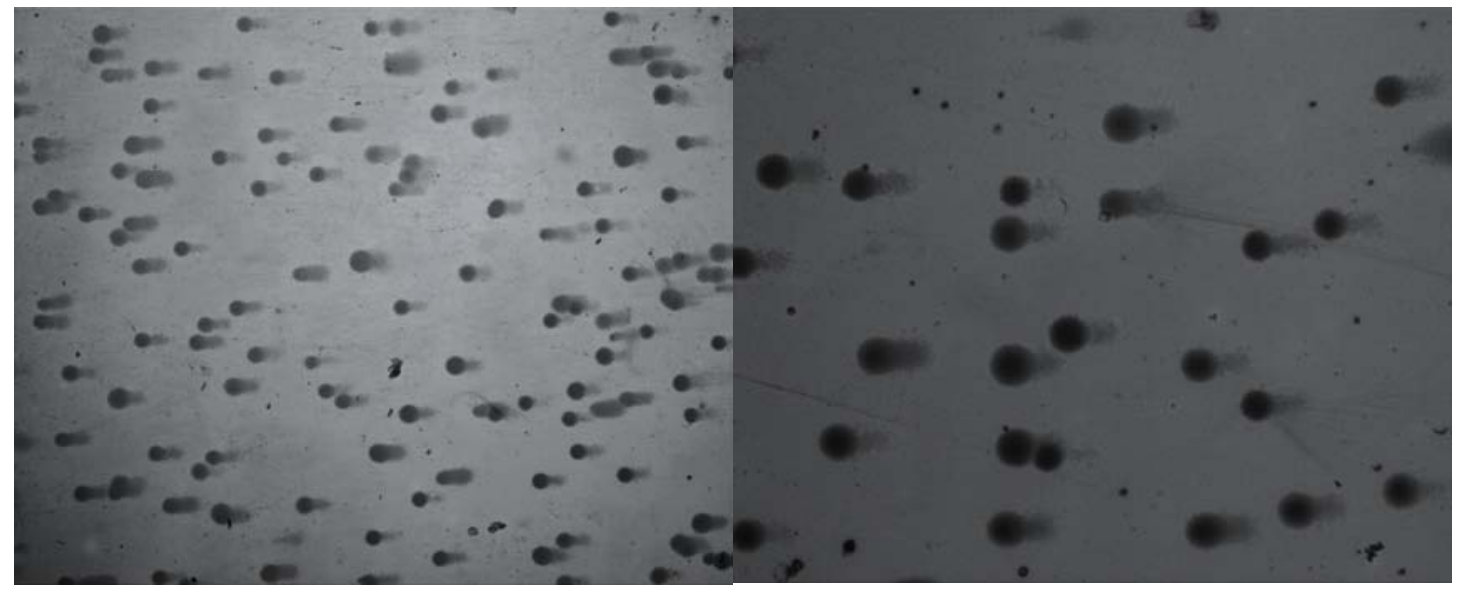

Figura 18 - Fotomicrografias de "cometas" de rato Wistar normal (A) ou submetido ao modelo do RH (B). Observa-se cometas com caudas de maior comprimento nos animais submetidos ao modelo de carcinogênese, resultado de uma maior intensidade de quebra do DNA. Fotos obtidas com objetiva de 5 e $10 \mathrm{X}$ respectivamente. 


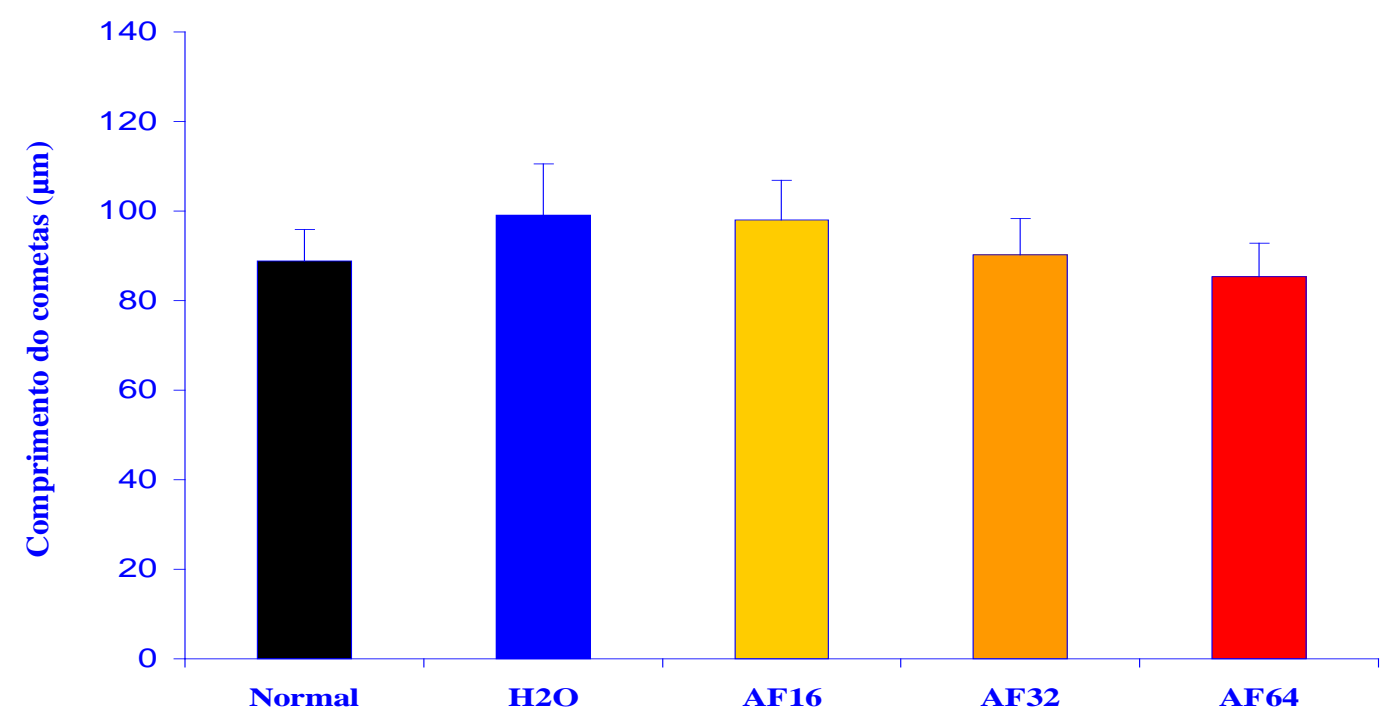

Figura 19 - Gráfico representativo do comprimento dos cometas e indicativo da intensidade de quebra do DNA das células hepáticas. Valores expressos como média \pm erro padrão da média de 711 animais e analisados por ANOVA ou Kruskal-Wallis,quando apropriado, adotando-se o nível de significância de $5 \%$.

\subsection{Padrão hepático de metilação global do DNA}

Avaliou-se também o padrão hepático de metilação global do DNA de ratos Wistar submetidos ao modelo do RH e tratados ou não com AF, através da técnica de Dot Blot.

O modelo de hepatocarcinogênese promoveu uma hipometilação global do DNA tanto quando da análise do tecido total, comparando-se o grupo $\mathrm{H}_{2} \mathrm{O}(4,08 \pm 2,38)$ com o grupo normal $(5,44 \pm 0,58)$ (Figura 20 A), quanto da análise das LPN microdissecadas $(9,39 \pm 4,59)$ em relação ao tecido normal ao seu redor ("surrounding”) $(22,48 \pm 13,94)$ (Figura 20 B) (diferenças estatisticamente não significantes $\mathrm{p}>0,05$ ). Destaca-se que observou-se uma diferença muito mais pronunciada no estado de hipometilação entre as LPN microdissecadas e o respectivo "surrounding”, do que entre o tecido total do grupo $\mathrm{H}_{2} \mathrm{O}$ e do grupo normal.

Em se tratando da análise do tecido inteiro (Figura 20 A), em relação ao grupo $\mathrm{H}_{2} \mathrm{O}$

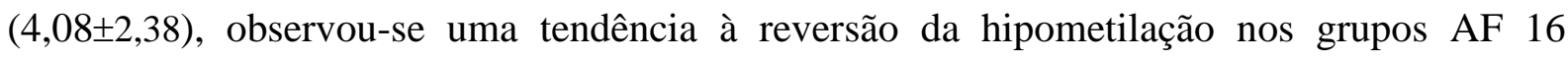
$(5,90 \pm 0,28)$ e o AF $64(6,29 \pm 0,86)(p>0,05)$. Por outro lado, no grupo AF $32(3,04 \pm 1,52)$, 
houve uma tendência à promoção de um estado de hipometilação ainda maior (Figura 20 A) (diferenças estatisticamente não significantes $\mathrm{p}>0,05$ ).

Nas LPN microdissecadas (Figura 20 B), com relação ao grupo $\mathrm{H}_{2} \mathrm{O}(9,39 \pm 4,59)$, todas as doses de AF tenderam a promover hipometilação ( $p>0,05)$, sendo que nos grupos AF $16(4,72 \pm 1,14)$ e $64(6,52 \pm 2,68)$ os valores tenderam a ser maiores do que no grupo AF 32 $(3,22 \pm 0,86)$, que se apresentou aproximadamente 3 vezes mais hipometilado do que o grupo $\mathrm{H}_{2} \mathrm{O}$ e duas vezes mais hipometilado do que o grupo AF 64 ( $\left.>>0,05\right)$.
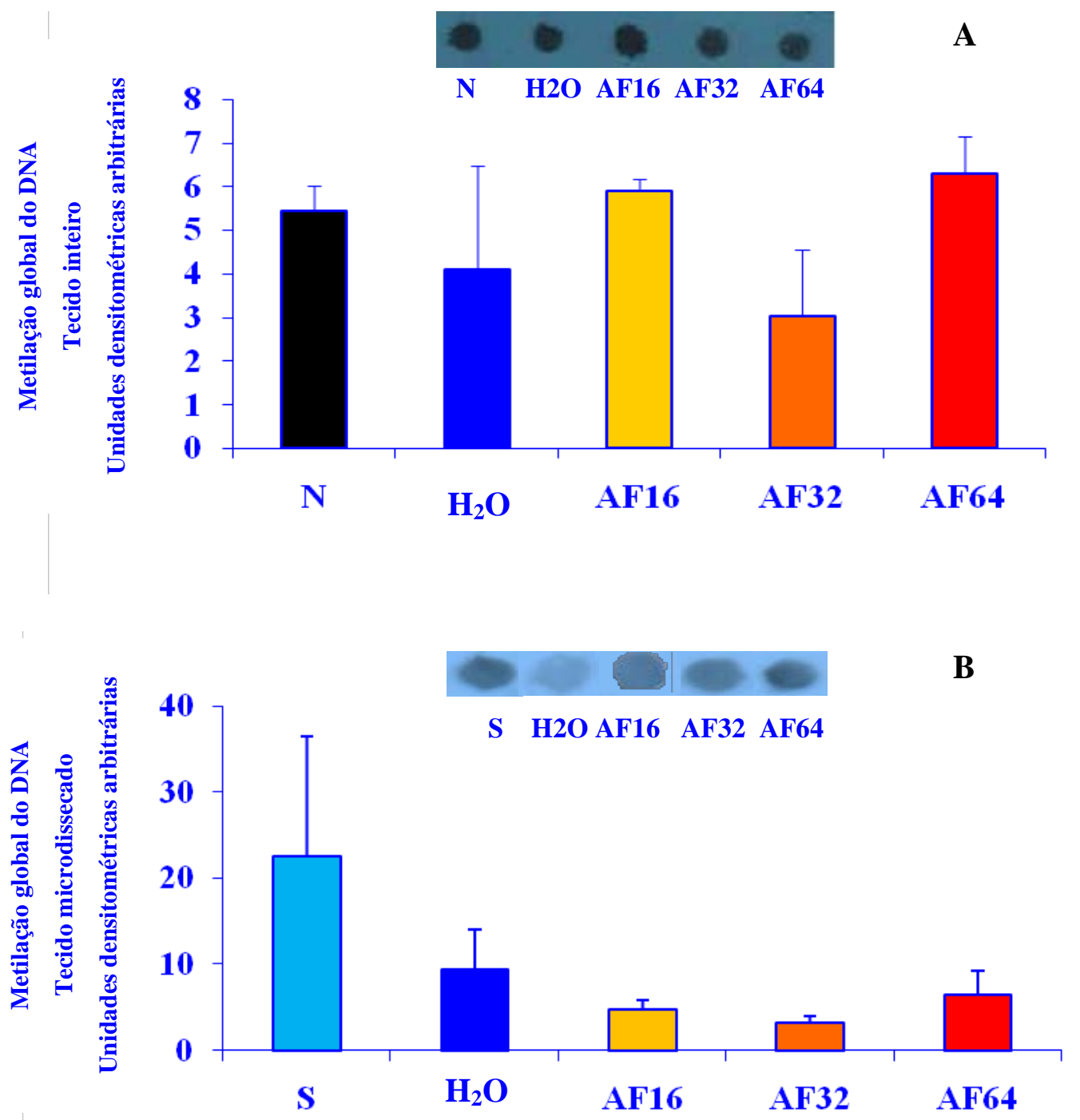

Figura 20 - Metilação global do DNA em tecido hepático inteiro (A) e microdissecado (B). Valores expressos como média \pm erro padrão da média de 3 animais e analisados por ANOVA ou Kruskal-Wallis, quando apropriado, adotando-se o nível de significância de 5\%. 


\subsection{Expressão hepática do proto-oncogene c-myc}

A técnica de RT-PCR foi utilizada para se avaliar a expressão hepática do protooncogene c-myc de ratos Wistar submetidos ao modelo do RH e tratados ou não com AF.

Ressalta-se que foi possível realizar a co-amplificação do proto-oncogene de interesse (c-myc) e do gene controle (GAPDH), o que aumenta a confiabilidade dos resultados, uma vez que a expressão dos genes de cada animal foi avaliada através de uma mesma reação de amplificação, controlando-se a interferência de possíveis pontos de erro e fatores externos que poderiam levar a diferenças entre reações de amplificação realizadas em oportunidades distintas e conseqüentes valores alterados de expressão do gene de interesse ou do seu controle.

A hepatocarcinogênese, em sua etapa de promoção, promoveu um aumento da expressão do proto-oncogene c-myc da ordem de 65\% tanto quando da análise do tecido total, comparando-se o grupo $\mathrm{H}_{2} \mathrm{O}(0,43 \pm 0,03)$ com o grupo normal $(0,26 \pm 0,06)$ (Figura 21 A), quanto da análise das LPN microdissecadas $(0,94 \pm 0,25)$ em relação ao tecido normal ao seu redor ("surrounding”) $(0,56 \pm 0,05)$ (Figura 21 B) ( $>>0,05$; diferenças estatisticamente não significantes).

A análise das LPN microdissecadas (Figura 21 B) permitiu observar uma redução da ordem de 30\% na expressão desse proto-oncogene nos grupos AF $16(0,66 \pm 0,01)$ e 64 $(0,74 \pm 0,02)$ e um aumento de aproximadamente $15 \%$ na expressão em resposta à dose de

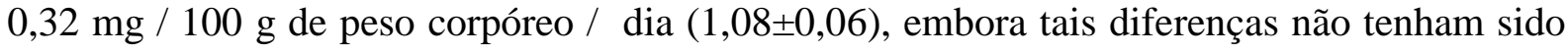
estatisticamente significantes ( $\mathrm{p}>0,05)$.

Destaca-se que esses efeitos não teriam sido identificados pela análise do tecido inteiro, onde todos os grupos AF $16(0,50 \pm 0,01)$, $32(0,43 \pm 0,02)$ e $64(0,41 \pm 0,05)$ apresentaram valores próximos aos observados no grupo $\mathrm{H}_{2} \mathrm{O}(0,43 \pm 0,03)$ (Figura 21 A). 

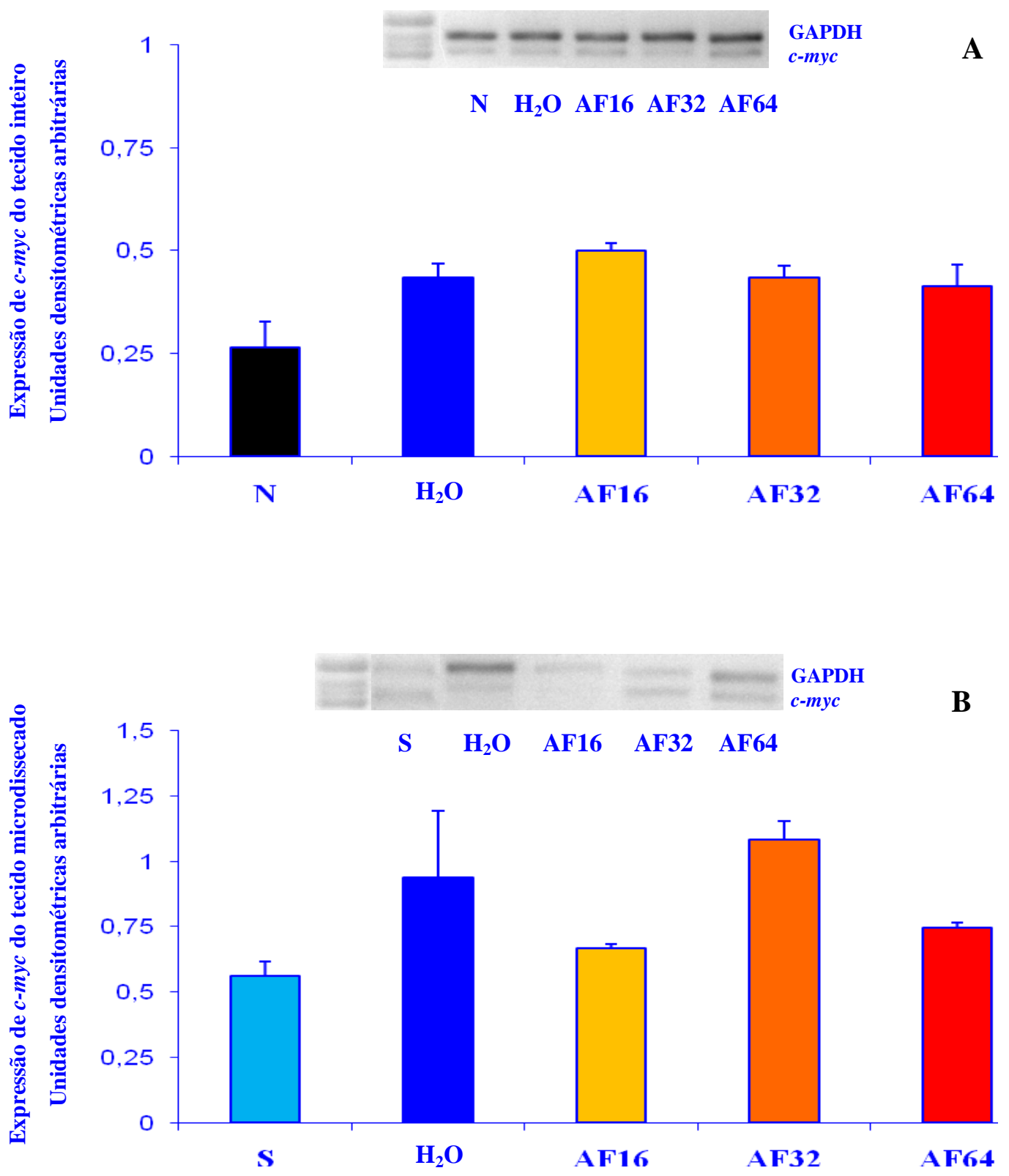

Figura 21 - Avaliação da expressão hepática de c-myc em tecido hepático inteiro (A) e microdissecado (B). Valores expressos como média \pm erro padrão da média de 3-5 animais e analisados por ANOVA ou Kruskal-Wallis, quando apropriado, adotando-se o nível de significância de $5 \%$. 


\subsection{Visão global dos efeitos das diferentes doses do AF nas LPN persistentes}

Técnicas de Análise Multivariada foram aplicadas e viabilizaram a análise e interpretação simultânea dos resultados dos 8 biomarcadores utilizados para avaliar os efeitos das diferentes doses suplementadas de AF nas LPN persistentes, consideradas locais de futura evolução para o câncer.

Assim, no dendograma (diagrama em forma de árvore) abaixo (Figura 22), de acordo com a separação promovida pela maior chave, podemos observar uma subdivisão em dois grupos principais: $\mathrm{H}_{2} \mathrm{O}$ e AF 64 (círculo azul) e AF 16 e 32 (círculo vermelho), o que constitui um indicativo de que os grupos tratados com $\mathrm{H}_{2} \mathrm{O}$ e AF 64 apresentaram um perfil de desenvolvimento da hepatocarcinogênese em sua etapa de promoção distinto dos grupos tratados com AF 16 e 32.

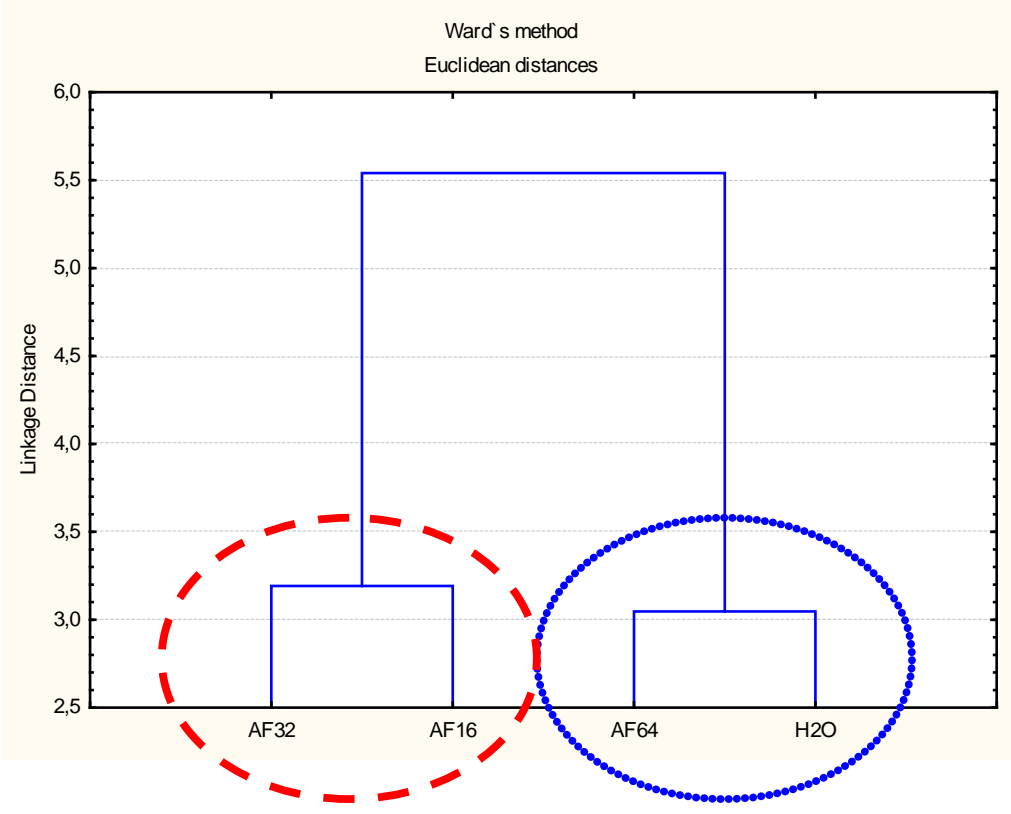

Figura 22 - Análise exploratória dos efeitos das diferentes doses de ácido fólico suplementadas. Agrupamento realizado pela Análise de Agrupamento Hieráquica considerando-se todos os biomarcadores utilizados na avaliação das LPN persistentes.

A análise do comportamento dos biomarcadores utilizados na avaliação das LPN persistentes em resposta aos tratamentos com diferentes doses de ácido fólico (Figura 23) confirmou que realmente os efeitos que o AF promove na hepatocarcinogênese diferem de acordo com a dose suplementada, de modo que os grupos AF 16 e 32 (Cluster 2) 
apresentaram maiores valores de multiplicidade, número área e \% da área ocupada por LPN persistentes e apoptose, e menor proliferação celular e metilação do DNA, não alterando a expressão de $c$-myc em relação aos grupos $\mathrm{H}_{2} \mathrm{O}$ e AF 64 (Cluster 1).

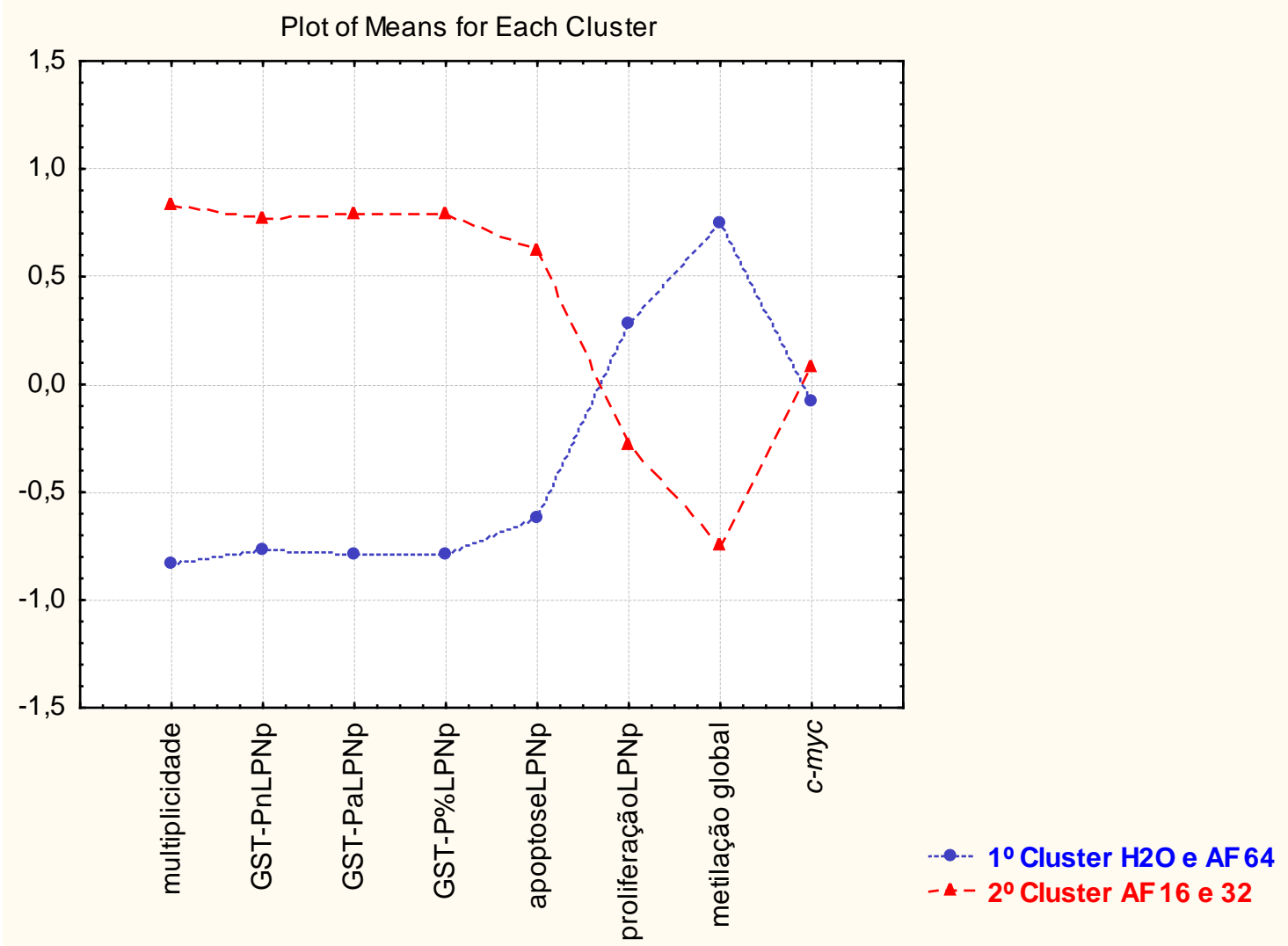

Figura 23 -Comportamento dos biomarcadores utilizados na avaliação das LPN persistentes em resposta aos tratamentos com diferentes doses de ácido fólico. Agrupamento realizado pela Análise de Agrupamento Não-hieráquica de K-means considerando-se todos os biomarcadores utilizados na avaliação das LPN persistentes.

Finalmente, na Análise de Componentes principais (PCA), pode-se observar que toda a informação contida nos 8 biomarcadores que avaliaram os efeitos do AF nas LPN persistentes pode ser explicada por 3 componentes principais (com autovalores acima de 1), sendo que os primeiros CP (1 e 2) retiveram grande parte da variância (medida de variabilidade dos dados) contida nas variáveis originais, respectivamente 65,09\% e 19,79\% (Tabela 4). Podemos observar ainda, que o CP-1 é o que retém mais informação (Tabela 4), de modo que a interpretação gráfica de acordo com o eixo X do gráfico da PCA (Figura 24) é a que caracteriza o fenômeno com maior robustez. 
Tabela 4- Caracterização dos componentes principais: autovalores e porcentagem de retenção da variabilidade e da informação contida nos biomarcadores.

\begin{tabular}{|c|c|c|c|c|}
\hline $\begin{array}{c}\text { Componentes } \\
\text { principais }\end{array}$ & Autovalores & $\%$ Total & Cumulative & Cumulative \\
\hline 1 & 5,207878 & 65,09847 & 5,207878 & 65,0985 \\
\hline 2 & 1,583797 & 19,79747 & 6,791675 & 84,8959 \\
\hline 3 & 1,208325 & 15,10406 & 8,000000 & 100,0000 \\
\hline
\end{tabular}

Assim, ao avaliar a dispersão dos grupos experimentais nos gráficos com a informação dos 8 biomarcadores condensada nos CP (CP-1 X CP-2 e CP-1 X CP-3), podemos observar que também essa técnica de Análise Multivariada identificou que nesse estudo os efeitos promovidos pelos tratamentos com o AF apresentaram perfis de resposta distintos que caracterizaram dois grupos: $\mathrm{H}_{2} \mathrm{O}$ e AF 64 e AF 16 e 32 (Figura 24).
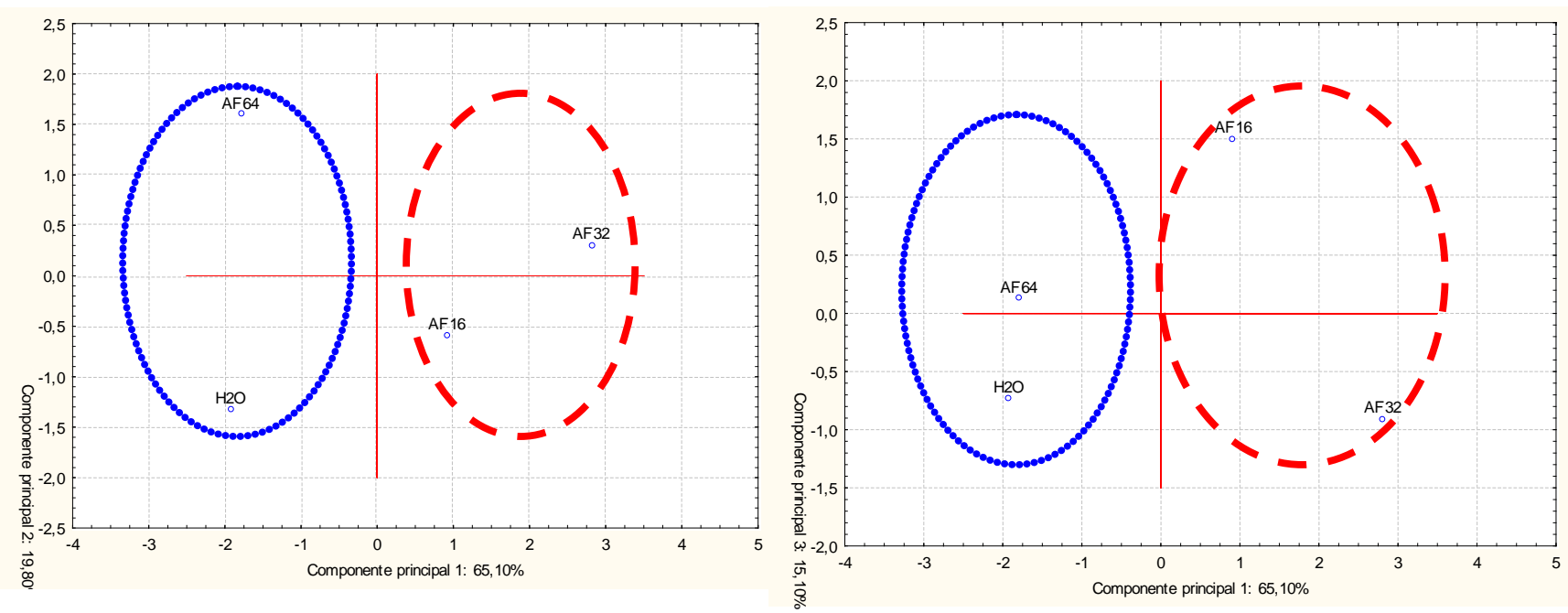

Figura 24 - Dispersões dos grupos experimentais segundo as informações dos biomarcadores utilizados para avaliar as LPN persistentes retidas nos componentes principais 1 e 2 (A) e 1 e 3 (B). 
Ainda, de acordo com a tabela de correlações entre os biomarcadores e os componentes principais (Tabela 5), pode-se concluir que o grupo localizado à esquerda do eixo X ( $\mathrm{H}_{2} \mathrm{O}$ e AF 64) apresentou como característica principal maiores valores de metilação global do DNA hepático (correlação negativa com o CP-1= -0,9) e o grupo localizado à direita do eixo X (AF 16 e 32) maiores valores de multiplicidade, número, área e \% da área do corte ocupada pelas LPN GST-P positivas persistentes (correlações positivas com o CP-1 da ordem de 0,9$)$.

Tabela 5- Correlações entre os biomarcadores e os componentes principais.

\begin{tabular}{l|ccc}
\multicolumn{1}{c}{ Biomarcadores } & CP1 & CP2 & CP3 \\
multiplicidade & 0,998310 & $-0,007567$ & 0,057612 \\
GST-PnLPNp & 0,921601 & $-0,377996$ & $-0,088146$ \\
GST-PaLPNp & 0,996116 & 0,068157 & $-0,055748$ \\
GST-P\%LPNp & 0,995887 & $-0,031350$ & $-0,085007$ \\
apoptoseLPNp & 0,491921 & $-0,681033$ & 0,542410 \\
proliferaçãoLPNp & $-0,417362$ & $-0,898996$ & $-0,132719$ \\
metilação global & $-0,903797$ & $-0,373559$ & $-0,208815$ \\
c-myc & 0,380579 & $-0,153897$ & $-0,911853$ \\
variância & $65,09 \%$ & $19,79 \%$ & $15,10 \%$ \\
\hline
\end{tabular}




\section{DISCUSSÃO}

Estudos dos efeitos do AF em animais há anos caracterizam-se por achados conflitantes e sugerem que os efeitos do folato nas neoplasias dependem de inúmeros fatores como raça do animal, modelo experimental adotado, tipo, tempo e dose da aplicação do carcinógeno, o estágio da carcinogênese e a forma e dose de AF administrada (GLYNN; ALBANES, 1994; LINDZON et al., 2009), fazendo-se indispensáveis estudos complementares na tentativa de elucidar os efeitos e os respectivos modos de ação do AF na carcinogênese, especialmente em órgãos ainda pouco explorados como o fígado.

De fato, a caracterização de agentes quimiopreventivos em modelos com animais permite avaliar diferentes dosagens e curvas de dose-resposta, de modo que compostos que demonstram elevada eficácia e pouca toxicidade em ensaios com animais representam candidatos para ensaios clínicos em seres humanos (GREENWALD, 2002).

Uma vez que o AF apresenta diferentes efeitos quando administrado nas diversas etapas do processo neoplásico (Figura 3) (SONG et al., 2000 a, b ; KIM 2007, LINDZON et al., 2009) é de grande importância a avaliação de seu eventual potencial quimiopreventivo em modelos de carcinogênese experimental como o do RH, que permitem a distinção das etapas iniciais pré-neoplásicas da carcinogênese (FARBER; SARMA, 1987; OLIVEIRA et al., 2001).

Dentre os estágios da carcinogênese, destaca-se o de promoção, por ser um processo longo e reversível, o que o caracteriza como um ponto estratégico para a ação de agentes quimiopreventivos (YOUNG et al., 2003). Além disso, uma vez que a grande maioria da população é submetida a diversos estímulos capazes de promover a iniciação ao longo da vida (conforme sugerido na Figura 3), agentes quimiopreventivos com ação em nível de promoção 
constituem uma estratégia potencialmente mais promissora do que aqueles que atuariam apenas na ausência do início do processo carcinogênico (CARBONE et al., 2004).

Nesse contexto, e, visando avaliar a hipótese de que o AF pode modular o processo carcinogênico através da participação em processos genéticos e epigenéticos essenciais à síntese, replicação e reparo do DNA, proliferação celular, apoptose e expressão gênica, realizou-se o presente estudo para avaliar os eventuais efeitos do AF, quando administrado especificamente durante a etapa de promoção da hepatocarcinogênese.

Recentemente descreveu-se que há diferenças no metabolismo do AF entre humanos e animais, sendo que doses muito mais altas teriam que ser administradas em animais na tentativa de simulação das condições plasmáticas que são observadas em humanos após a ingestão de AF para, só assim, acessar adequadamente o impacto da exposição sistêmica à vitamina (WRIGHT et al., 2007).

Desse modo, no presente estudo, na tentativa de se modular a hepatocarcinogênese já na fase de promoção, adotou-se doses de AF relativamente elevadas (8, 16 e 32 vezes a RDA), procedimento esse que foi inclusive, posteriormente recomendado por Lindzon e col. (2009).

Além disso, considerando ainda a política de fortificação implementada em diversos países e o uso abusivo de suplementos alimentares por grandes grupos populacionais, como é o caso de $30-40 \%$ dos norte-americanos (RADIMER et al., 2004), os resultados observados no presente estudo foram obtidos em condições metabólicas com relação ao AF que podem ser consideradas similares às encontradas em humanos.

Assim, os resultados obtidos nesse trabalho indicam, de forma inédita, que na hepatocarcinogênese, assim como previamente descrito em modelo de carcinogênese de cólon (KIM, 2003, 2004, 2007), a ação do AF é dependente tanto da dose quanto da etapa da carcinogênese em que o tratamento é iniciado. 
Dados preliminares de estudo em andamento em nosso grupo de pesquisa indicam que o AF, na dose de 8 vezes a RDA, apresenta ação quimiopreventiva se administrado continuamente nas etapas de iniciação e promoção do modelo de hepatocarcinogênese do RH.

Já na suplementação na etapa de promoção, conduzida no presente estudo, quando as LPN já se encontravam estabelecidas, as duas menores doses utilizadas (8 e 16 vezes a RDA - grupos AF 16 e 32) não apresentaram ação quimiopreventiva (Tabela 3 e Figuras 11, 12 e 13), diferentemente do que foi observado na maior dose testada (32 vezes a RDA - grupo AF 64), a qual esteve associado a uma diminuição significativa na porcentagem de lesões maiores ou iguais a 1 em relação ao grupo $\mathrm{H}_{2} \mathrm{O}$ (controle) $(\mathrm{p}<0,05)$ (Tabela 3), permitindo, ainda, constar uma tendência ( $\mathrm{p}>0,05)$ de redução do número (Figura 11) e porcentagem da área ocupada (Figura 13) pelas LPN GST-P positivas persistentes.

De fato, há cerca de 10 anos atrás, grandes grupos de pesquisa como o de Kim e colaboradores (1996) observaram que o AF, quando administrado por 20 semanas para ratos submetidos ao modelo de câncer coloretal na fase de iniciação e promoção, em doses pouco inferiores (0, 1 e 4 vezes a RDA) à menor dose utilizada no presente estudo (8 vezes a RDA), apresenta uma capacidade de reduzir com um perfil dose-dependente a proporção de ratos com tumores macroscópicos e a média de tumores por rato, desde que na dose de até 4 vezes a RDA. No entanto, a última dose utilizada, de 20 vezes a RDA, não seguiu tal tendência e além de não ter tido o efeito benéfico, tendeu a aumentar a proporção de ratos com tumores macroscópicos e a média de tumores por rato (KIM et al., 1996).

Fenômeno similar também foi identificado no estudo de Song et al. (2000b), que constataram que o AF apresentou efeito quimiopreventivo, reduzindo o número de ACFs e de pólipos ileais durante os 3 meses iniciais da evolução do processo carcinogênico, período no qual as concentrações plasmáticas de AF estavam inversamente correlacionadas com o número de pólipos ileias e de ACFs, sendo a dose mais efetiva a de 10 vezes a RDA. 
Porém, em etapas mais avançadas (6 meses), a administração de doses de AF da ordem de 1, 4 e 10 vezes a RDA promoveu um aumento da ordem de 70\% no número de pólipos ileais em relação a um grupo que ingeriu ração sem AF. Os autores observaram ainda que nessa oportunidade as concentrações plasmáticas de AF estavam diretamente correlacionadas com o número de pólipos ileias (SONG et al., 2000b).

Do mesmo modo, diante da suplementação na etapa de promoção do modelo de hepatocarcinogênese do RH, as doses de 8 e 16 vezes a RDA de AF permitiram observar que, além de não ter sido constatada quimioprevenção, houveram parâmetros que indicaram uma tendência $(p>0,05)$ à promoção da carcinogênese, uma vez que essas doses induziram, respectivamente, um aumento de multiplicidade da ordem de 4 e 6 vezes (Tabela 3), assim como maior número, área e porcentagem da área ocupada pelas LPN GST-P positivas persistentes (Figuras 11, 12 e 13).

Ressalta-se que a dose suplementada no grupo AF 32, de 16 vezes a RDA, está justamente no intervalo das doses utilizadas por Kim e col. (1996) (20 vezes a RDA) e Song e col. (2000b) (10 vezes a RDA) e que tal dose deu indícios de uma ação promotora da carcinogênese desde o momento da macroscopia, quando constatou-se que havia promovido aumento da porcentagem de LPN maiores ou iguais a 1 em relação ao grupo $\mathrm{H}_{2} \mathrm{O}$ (controle) $(\mathrm{p}<0,05)$ (Tabela 3).

Interessantemente, outro estudo que avaliou os efeitos da suplementação do AF na dose de 12,5 vezes a RDA (a qual também está dentro do intervalo analisado no presente estudo), constatou um aumento significativo de 70\% no risco de mortalidade por câncer em gestantes (CHARLES et al., 2004).

Além disso, recentemente, Lindzon e col. (2009) constataram que o AF, mesmo em doses baixas (2,5 e 4 vezes a RDA) já apresentou efeito promotor de tumor na etapa de progressão de ACFs a tumores coloretais em ratos. 
Assim, a análise macro e microscópica das LPN hepáticas marcadas pela GST-P, indica que os efeitos do AF na promoção da hepatocarcinogênese em ratos dependem de sua dose e, além disso, sabe-se que o AF pode exercer tais efeitos através da modulação de fenômenos como a proliferação celular, por estar envolvido na síntese e metilação do DNA.

Os efeitos do AF na carcinogênese podem estar associados ao fato dessa vitamina ser elemento essencial na síntese de novo de purinas (A e G) e do timidalato e, por isso apresentar um papel essencial na síntese, replicação e reparo do DNA, no ciclo celular e na apoptose (DUTHIE et al., 2002; LARSSON et al., 2006). Assim, a deficiência pode prejudicar esses importantes processos envolvidos com a carcinogênese, onde as células apresentam aceleradas taxas de replicação e divisão celular (BASTEN et al., 2006) e a suplementação poderia, potencialmente, reverter tais fenômenos.

De fato, como é de se esperar no processo carcinogênico característico por descontrole em nível de proliferação celular, no presente estudo foram constatadas maiores taxas de proliferação celular nas LPN hepáticas (persistentes e em remodelação) do que no “surrounding” ( $p>0,05)$ (Figura 15).

Além disso, os resultados obtidos estão de acordo com estudos recentes de nosso grupo de pesquisa com o modelo de hepatocarcinogênses do RH (MAZZANTINI et al., 2008; KUROIWA-TRZMIELINA et al., 2009), uma vez que observou-se, ainda, uma maior proliferação celular nas LPN persistentes, que tendem a evoluir para o câncer do que nas LPN em remodelação, que tendem a voltar a normalidade ( $p>0,05)$ (Figura 15) .

Estudos da literatura observaram que o AF inibe a proliferação celular in vitro (CHOI; MASON, 2002), in vivo em ratos submetidos à hepatectomia parcial (KOMATSU; TSUKAMOTO, 1998) e em modelos de carcinogênese gástrica (FEI et al., 2006), inclusive em humanos com pólipos adenomatosos recorrentes (KHOSRAVIANI et al., 2002). 
Do mesmo modo, no presente trabalho, observou-se uma a redução da proliferação celular $(\mathrm{p}<0,05)$ induzida nos grupos AF 32 e 64 principalmente nas LPN persistentes, justamente as que mais proliferam, indicando maior agressividade e capacidade de evoluir para o câncer (Figura 15).

Aventa-se que esse fenômeno possa ter sido mediado por alterações no metabolismo da homocisteína e dos metabólitos do AF como DHF e 5-metil-THF (STANGER 2002), resultantes da suplementação, conforme sugerido na sequência de eventos 1 a 8 da Figura 25, que descreve que altas concentrações de AF (1) resultam no aumento de SAH que, por um mecanismo de “feedback” negativo inibe a MT (3) [foram detectadas inibições da ordem de 50-70\% (STANGER, 2002)], causando simultaneamente redução do processo de metilação (4) e acúmulo de SAM (5), a qual também por mecanismo de "feedback" negativo inibe a MTHFR (6), o que afeta severamente a distribuição de folato e o funcionamento celular, causando, em última instância, a redução da produção de homocisteína (7) e, consequentemente da proliferação celular (8) (STANGER, 2002; ULRICH, 2005) . 


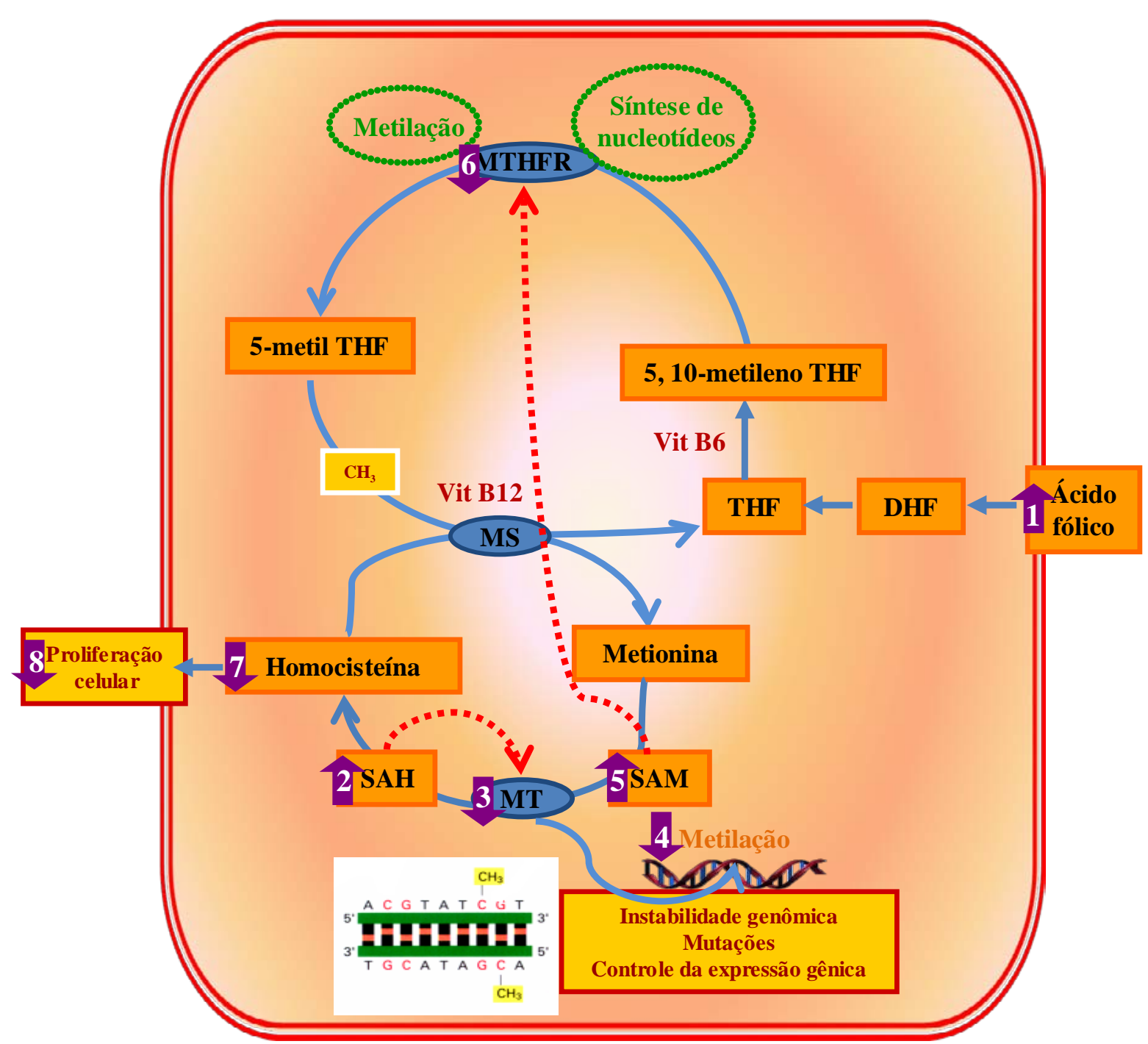

Figura 25 - Possíveis efeitos metabólicos da suplementação com AF nos processos de metilação do DNA e proliferação celular. DHF, dihidrofolato; THF, tetrahidrofolato; SAM, s-adenosil-metionina; SAH, s-adenosil-homocisteína; MTHFR, metileno-tetrahidro-folatoredutase; MS, metionina sintetase; MT, metil transferases. A sequência de números nas setas roxas indica os possíveis efeitos da suplementação com o AF no metabolismo da homocisteína, proliferação celular e metilação do DNA. As setas vermelhas indicam pontos onde ocorre "feedback” negativo. Segundo Ulrich (2005).

Embora não se tenha plena compreensão dos mecanismos anti-proliferativos do AF, é sabido que ele apresenta uma ação indireta na redução dos níveis de homocisteína (STANGER 
2002). Assim, suas concentrações são inversamente proporcionais às de homocisteína, a qual causa aumento na proliferação celular (SOHN et al., 2003; AKOGLU et al., 2004).

Além disso, os metabólitos do AF, principalmente o 5-metiltetrahidrofolato, inibem a proliferação celular e são capazes de reverter os potentes efeitos promotores de crescimento celular da homocisteína em células de câncer de cólon humano CaCo-2, sendo possivelmente os principais moduladores dos efeitos anti-proliferativos do AF nesse modelo de carcinogênese (AKOGLU et al., 2004).

De qualquer modo, nesse experimento, a redução da proliferação não implicou em papel protetor significativo na hepatocarcinogênese em sua etapa de promoção, como se pode observar pela análise das LPN GST-P positivas (Figuras 11, 12 e 13).

Bashir e colaboradores (2004) avaliaram efeitos da suplementação com AF em neoplasias e constataram que nem sempre a redução da proliferação pode ser considerada protetora no processo carcinogênico, uma vez que eles observaram que tanto a deficiência quanto a super-suplementação com vitaminas (entre elas o AF) promoveu redução da proliferação celular em camundongos com neoplasias intestinais, mas ao mesmo tempo aumentaram o processo neoplásico intestinal.

No entanto, a redução pronunciada $(70-85 \%)(p<0,05)$ da proliferação celular observada no grupo AF 64 (Figura 15) pode ser um dos fatores envolvidos com a diminuição significativa na porcentagem de lesões maiores ou iguais a 1 em relação ao grupo $\mathrm{H}_{2} \mathrm{O}$ (controle) $(\mathrm{p}<0,05)($ Tabela 3) e com a tendência $(\mathrm{p}>0,05)$ à redução do número (Figura 11) e porcentagem da área ocupada (Figura 13) pelas LPN GST-P positivas persistentes induzidas pela suplementação com essa dose de AF.

No que se refere ao fenômeno complementar e oposto à proliferação celular, a apoptose, considerada também um biomarcador da carcinogênese (GOBE et al., 2002; WATANABE, 2002; THOMADAKI et al., 2006), observou-se que o AF tendeu a inibir esse 
fenômeno de maneira dose-dependente, mas não teve uma ação pronunciada (Figura 15). Assim, como as diferenças não atingiram significância estatística, é provável que esse não seja um dos mecanismos primordiais à ação moduladora do AF na promoção da hepatocarcinogênese.

Esse resultado está de acordo com um dos poucos estudos que avaliam os efeitos do AF na apoptose, onde o AF e seus metabólitos também não promoveram indução da apoptose na carcinogênese colônica (AKOGLU et al., 2004).

Então, observa-se que, no balanço proliferação-apoptose, apesar de o AF reduzir a proliferação celular (Figura 15), tende a inibir a apoptose (Figura 17), de modo que possivelmente os dois mecanismos de contrabalancearam na direção de um equilíbrio, resultando na ausência de uma modulação efetiva do processo carcinogênico por esses mecanismos.

Outro fenômeno característico do processo carcinogênico que foi observado no presente estudo é o aumento de danos ao DNA, que foi induzido pela aplicação do modelo de hepatocarcinogênese do $\mathrm{RH}$, de modo que o grupo $\mathrm{H}_{2} \mathrm{O}$ (controle) apresentou mais danos do que o grupo normal ( $\mathrm{p}>0,05)$ (Figura 19), confirmando achados prévios de nosso grupo de pesquisa com esse mesmo modelo de hepatocarcinogênese (ONG et al., 2006).

Sabe-se que o AF também poderia modular a carcinogênese por apresentar potenciais efeitos na prevenção de danos ao DNA e instabilidade genômica (BULL; FENECH, 2008). No entanto, observou-se que, na etapa de promoção da hepatocarcinogênese, o tratamento com AF, mesmo em diferentes doses (grupos AF16, AF32 e AF64), não promoveu aumento e nem redução dos danos ao DNA em nenhum dos grupos suplementados (Figura 19). Sendo assim, é provável que esse também não esteja entre os principais mecanismos envolvidos com a ação moduladora do AF nessa fase da hepatocarcinogênese. 
Os resultados obtidos estão de acordo com a constatação recente de que a suplementação com AF em humanos, com a dose de 3 vezes a RDA por 3 meses, não promoveu redução nos danos ao DNA também avaliados pela técnica do Cometa (BASTEN et al., 2006).

Diversos estudos relatam que a metilação aberrante do DNA é o principal evento comum nos estágios pré-neoplásicos e neoplásicos do carcinoma hepatocelular e pode constituir um biomarcador precoce, sendo alvo para tratamento e quimioprevenção do câncer de fígado (CALVISI et al., 2007).

Assim, conforme amplamente descrito na literatura (JONES; BAYLIN 2002; TAO et al., 2004; BASTEN et al., 2006), inclusive especificamente na hepatocarcinogênese (POGRIBNY; BELAND, 2009), constatou-se, tanto no tecido total (Figura 20 A) quanto em LPN hepáticas induzidas pelo modelo do RH e microdissecadas, a ocorrência da hipometilação global do DNA já na etapa de promoção (Figura 20 B).

Desse modo, por se tratar de um evento precoce na progressão das neoplasias e ser um achado universal nos tumores, a hipometilação do DNA representa um biomarcador com mais potencial a ser utilizado no processo da quimioprevenção do que a hipermetilação da região promotora de alguns genes, evento esse, mais específico e raro (TAO et al., 2004).

Avaliando-se o perfil epigenético das LPN hepáticas microdissecadas, constatou-se que as mesmas apresentam-se duas vezes mais hipometiladas $(p>0,05)$ do que $o$ “surrounding” (Figura 20 B), de modo que é possível estabelecer um paralelo com estudos que identificaram um DNA globalmente mais hipometilado em tecido canceroso extraído cirurgicamente em relação à mucosa gástrica não ou pré-cancerosa do mesmo paciente (FANG et al., 1996). 
De modo semelhante, em se tratando de câncer coloretal, regiões aparentemente normais de mucosas de pacientes com carcinomas apresentaram-se mais hipometiladas do que mucosas de pacientes saudáveis (CRAVO et al., 1994).

Sendo assim, técnicas refinadas como a microdissecção tecidual permitem a separação e estudo de fenômenos que ocorrem especificamente nas LPN, como a hipometilação global do DNA, ainda em fases pré-neoplásicas.

Devido ao potencial de reversibilidade, a restauração do balanço epigenético é uma interessante medida para se modular o desenvolvimento do câncer. Nesse sentido, descreve-se que diversos nutrientes e compostos bioativos podem influenciar a programação epigenética (DELAGE; DASHWOOD, 2008), através de mecanismos como a metilação do DNA, resultando em alteração da expressão de proto-oncogenes e genes supressores de tumor. Assim, pelo fato do AF ocupar uma posição de destaque no metabolismo dos grupamentos metila, diversos estudos associaram esta vitamina ao câncer.

Sabe-se que um adequado fornecimento de folato é pré-requesito para a metilação adequada do DNA e, de fato, observou-se que nos grupos AF 16 e AF 64 houve uma tendência de reversão da hipometilação no tecido hepático total (p>0,05) (Figura 20 A), eventualmente devido ao papel central do AF na síntese de SAM, doadora universal de grupamentos metil para as reações de metilação (Figura 2) (KIM, 2007; ROSS 2003).

Por outro lado, no grupo AF 32 observou-se uma tendência à promoção de um estado de hipometilação ainda maior ( $p>0,05$ ) (Figuras 20 A e B), o que seria um indicativo de pior prognóstico da carcinogênese, uma vez que a hipometilação pode implicar na ativação de proto-oncogenes e aumento da instabilidade genômica e das mutações (KIM, 2007).

Resultados similares foram obtidos em diferentes estudos onde se observou que a suplementação com AF promoveu redução no grau de metilação genômica do DNA hepático 
(KIM et al., 1997; SONG et al., 2000a) e induziu hipometilação na mucosa retal de pacientes com adenomas colônicos (CRAVO et al., 1998).

No entanto, como no presente experimento, na etapa de promoção, as diferenças observadas não foram estatisticamente significantes, conclui-se que possivelmente o AF não promoveu alterações efetivas no padrão de metilação genômica do DNA, de acordo com observações prévias em modelos animais de carcinogênese colônica (KIM et al., 1996; LE LEU et al., 2000 a, b; SOHN et al., 2003; SONG et al., 2000a) e mamária (KIM, 2003) e em estudos com suplementação em humanos (BASTEN et al., 2006; CRAVO et al., 1995; CRAVO et al., 1998; FENECH et al., 1998).

De fato, a suplementação com diversas doses de AF, entre elas, 1, 4 e até 20 vezes a RDA, em diferentes modelos animais, também não promoveu alterações no padrão de metilação genômica do DNA colônico (KIM et al., 1996; LE LEU et al., 2000 a, b; SONG et al., 2000a; SOHN et al., 2003) e mamário (KIM et al., 2003), de modo que é provável que os efeitos quimiopreventivos da carcinogênese promovidos pelo AF nesses estudos não tenham sido modulados por este mecanismo.

Inclusive, foi relatado que nem a suplementação em humanos com 3 a 12,5 vezes a RDA de AF alterou o padrão de metilação global do DNA (CRAVO et al., 1995 CRAVO et al., 1998; FENECH et al., 1998; BASTEN et al., 2006).

Outros autores observaram mais recentemente que a suplementação com altas doses de AF (12,5 vezes a RDA / dia) não promoveu alteração na metilação da região promotora de genes supressores de tumor em indivíduos com adenomas coloretais prévios, mas tendeu a aumentar a metilação, de modo considerado pró-carcinogênico (VAN DEN DONK, et al., 2007). 
Especificamente em fígado de ratos, Kotsopoulos et al. (2008) observaram que a suplementação com 4 vezes a RDA de AF, se administrada em animais adultos, não promoveu alterações no padrão de metilação genômica do DNA hepático.

Por outro lado, há estudos que observaram que a depleção de AF leva à hipometilação global do DNA (BALAGUI; WAGNER, 1993; JACOB et al., 1998; KIM 1999; RAMPERSAUD et al., 2002) e pode, por isso, aumentar o risco de transformações malignas (BASTEN et al., 2006).

No entanto, há também estudos em humanos (FENECH et al., 1998) e animais (KIM et al., 1995; KIM 1996; DUTHIE et al., 2000; LE LEU et al., 2000a, b; SONG et al., 2000 a, b; SOHN et al., 2003; KIM, 2004; BOLLHEIMER et al., 2005) que observaram que uma depleção moderada de AF (da ordem de 0 vezes a RDA) não promoveu hipometilação genômica do DNA colônico ou hepático e do proto-oncogene c-myc (KIM et al., 1995).

Assim, sugere-se que a modulação do padrão de metilação genômica pode ser resistente aos efeitos da deficiência ou suplementação com o AF ao menos em determinados tecidos (KIM et al., 1995; SOHN et al., 2003) e que é possível que a metilação global do DNA seja mais sensível à deficiência do que à suplementação com AF (BASTEN et al., 2006). Além disso, Choi e Mason (2000) sugeriram que é possível que ratos apresentem uma maior resistência à indução da metilação genômica do que humanos.

Na tentativa de se compreender esse fenômeno, sugere-se que a suplementação com AF poderia promover hipometilação devido a um mecanismo de "feedback" inibitório da DNMT, de forma análoga ao que se observa na deficiência de AF e, consequentemente, de doadores de grupamento metila, a qual promove um aumento na metilação devido a um mecanismo de “up regulation” da atividade da DNA metiltransferase hepática de ratos (SOHN et al., 2003) . 
Assim, conforme sugerido nas etapas 3 a 5 da Figura 25, o fenômeno observado no presente estudo de o AF causar hipometilação, apesar de estar diretamente envolvido com o fenômeno biológico de doação de grupamentos metil, pode ser explicado por um mecanismo de “down regulation” da DNA metiltransferase em resposta ao aumento da biodisponibilidade de SAM e SAH (KIM 1999; SONG et al., 2000 a, b). Inclusive, esse pode ser um dos mecanismos envolvidos com a potencialização da carcinogênese observada em LPN já estabelecidas.

De fato, relata-se uma atividade aumentada das DNMT em células tumorais e que a deficiência de metil também pode aumentar sua atividade (ROSS, 2003); então, parece plausível que a suplementação com AF possa diminuí-la por um mecanismo de "feedback" negativo.

Como pode-se observar na sequência 1-8 da Figura 25, a suplementação com AF promove uma sequência de alterações no metabolismo do AF e da homocisteína que caracterizam um possível modo de ação mediador conjunto dos efeitos do AF na redução da proliferação celular (Figura 15) e aumento da hipometilação do DNA (Figura 20 A e B).

Outro potencial biomarcador da carcinogênese é o proto-oncogene c-myc, considerado, inclusive, um mediador central da carcinogênese hepática (KAPOSI-NOVAK et al., 2009).

Assim, no presente estudo, o modelo de hepatocarcinogênese do RH promoveu um aumento da expressão hepática desse proto-oncogene ( $\mathrm{p}>0,05)$ tanto na análise do tecido total, quanto especificamente de LPN microdissecadas (Figuras 21 A e B), de acordo com achados prévios da literatura especificamente na hepatocarcinogênese (GARCEA et al., 1989; SIMILE et al.,1994; PASCALE et al., 1996; KAPOSI-NOVAK et al., 2009).

Com relação aos efeitos do AF na expressão hepática do proto-oncogene $c$-myc, os resultados apontam para a mesma direção do observados na análise de metilação global, ou 
seja, há doses de AF (grupos AF 16 e 64) que atuaram no sentido de inibir a carcinogênese, uma vez que reduziram a expressão do proto-oncogene c-myc $(\mathrm{p}>0,05)$ (Figura 21 B), o que pode ter sido inclusive mediado pela tendência à reversão da hipometilação global do DNA (Figura 20 A) e outra (grupo AF 32) que teria ação no sentido inverso, aumentando a expressão de $c$-myc $(\mathrm{p}>0,05)$ (Figura 21 B), o que também pode ter sido influenciado por um quadro de maior hipometilação global do DNA induzido pelo AF especificamente nessa dose (Figura 20 A).

Esses resultados estão de acordo com Kaposi-Novak et al. (2009) e Chen et al. (2004), que, em estudos utilizando até mesmo “microarray” para avaliar a carcinogênese hepática também não detectaram alterações na expressão de c-myc, de modo que Kaposi-Novak e col. (2009) sugerem que esteja ocorrendo uma modificação pós-transcricional que afete a meiavida da proteína c-myc ao invés de alterações em nível de expressão gênica.

Ressalta-se que o referido fenômeno não teria sido identificado pela análise do tecido hepático total (Figura 21 A) que, além da heterogeneidade inerente às próprias células neoplásicas, é composto por uma mistura de uma variedade de células hepáticas normais (não iniciadas), células do estroma, infiltrados inflamatórios e células endoteliais. Sendo assim, a presença de múltiplos tipos celulares provoca diluição das alterações significantes que ocorrem em células específicas e faz com que mesmo métodos sofisticados de biologia molecular apresentem valor limitado quando aplicados ao tecido total.

Desta forma, uma vez que o estudo de alterações genéticas moleculares requer uma correlação precisa entre populações celulares definidas e características genéticas moleculares, a microdissecção tecidual representa um procedimento essencial para a avaliação molecular específica de LPN (FEND; RAFFELD, 2000) e, ressalta-se que, tanto quanto se sabe, os resultados desse estudo são os primeiros da literatura acerca dos efeitos do AF especificamente em LPN hepáticas da fase de promoção microdissecadas. 
Assim, apesar da metilação global do DNA e a expressão de c-myc não terem sido significativamente alteradas pelo tratamento com diferentes doses de AF (0,16;0,32 e 0,64 mg / 100 g de peso corpóreo / dia) e, não estarem, provavelmente, entre os principais mecanismos modulados pelo AF na etapa de promoção da carcinogênese, ambos os parâmetros indicam que a dose intermediária (0,32 mg / 100 g de peso corpóreo / dia) apresentou uma ação promotora e a superior (0,64 mg / 100 g de peso corpóreo / dia) uma ação inibitória da carcinogênese.

Do mesmo modo que no presente estudo, diversos estudos constataram o comportamento não linear de diferentes doses de AF na quimioprevenção (BAGGOTT et al., 1992; KIM et al., 2003; KOTSOPOULOS et al., 2003; STOLZENBERG-SOLOMON et al., 2006), de modo que se começa a identificar um perfil de resposta biológica do AF, conforme sugerido por Van Guelpen et al. (2006), que relata que mesmo em estudos epidemiológicos, identificou-se recentemente, pela primeira vez, que as concentrações plasmáticas de folato estão significativamente relacionadas ao risco de câncer coloretal de um modo em formato de sino, conforme sugerido na Figura 26.

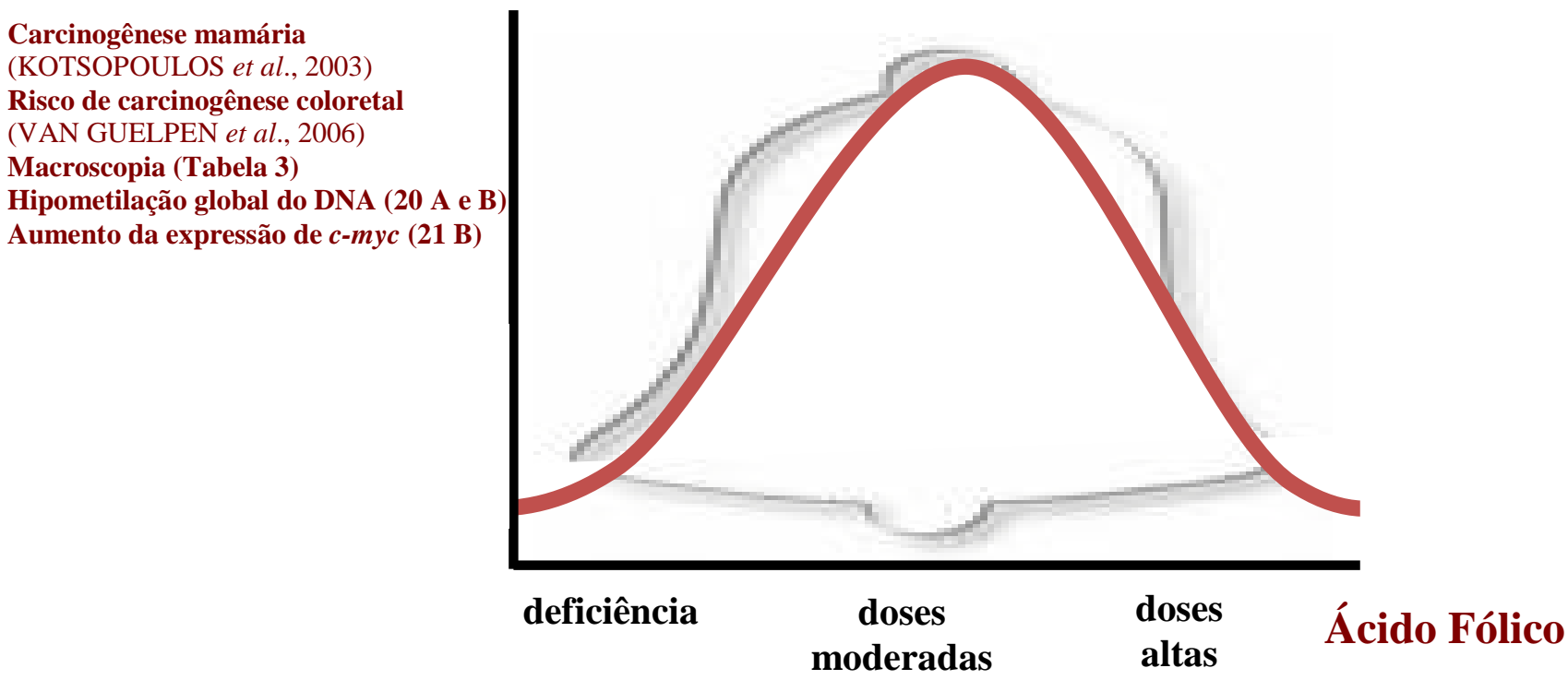

Figura 26 - Representação da curva de resposta dos efeitos de doses distintas do AF na carcinogênese. 
Inclusive, Wargovich e col. (1996) em seu estudo, observaram que o efeito promotor do AF na carcinogênese coloretal constatado na dose de 1250 vezes a RDA foi revertido ao se duplicar essa dose (2500 vezes a RDA). De fato, de forma análoga ao se passar da dose de 16 para 32 vezes a RDA no presente estudo, a tendência à piora da carcinogênese deixou de ser observada.

Além disso, o AF apresenta modo de ação similar em outros parâmetros biológicos, como na citotoxicidade de células de defesa matadoras naturais ("Natural Killers”-NK), uma das primeiras linhas de defesa da imunidade inata contra a carcinogênese, que apresentam menor atividade diante da deficiência ou altas concentrações de AF (TROEN et al., 2005).

Esse fenômeno pode ser explicado por um modelo matemático que além de ressaltar a não lineariedade do complexo sistema metabólico do AF, compostos por três ciclos interligados, indica que altas doses de folato podem favorecer condições bioquímicas similares às encontradas na deficiência (NIJHOUT et al., 2004).

De fato, sugere-se que para resolver o quebra-cabeça da relação do folato com o câncer será necessária um integração multidisciplinar entre estudos epidemiológicos, clínicos, da nutrição experimental e modelagem matemática (ULRICH, 2005).

Importa ressaltar que no presente trabalho, embora muitos dos efeitos do AF não tenham atingido significância estatística, observou-se uma convergência dos resultados da macro (Tabela 3) e da microscopia (Figuras 11, 12, 13, 15 e 17), assim como com os principais biomarcadores avaliados por técnicas de biologia molecular, como a hipometilação global do DNA (Figura 20 A e B) e a expressão de c-myc (Figura 21 B) e foi possível a identificação de um padrão de resposta, que pode ser caracterizado como uma curva em forma de sino, que corrobora observações de ação do folato em diferentes parâmetros biológicos (KOTSOPOULOS et al., 2003; TROEN et al., 2005; VAN GUELPEN et al., 2006) (Figura 26). 
Além disso, lançando-se mão de técnicas estatísticas e exploratórias que compreendem a Análise Multivariada na tentativa de se caracterizar os efeitos promovidos pelas diferentes doses de AF suplementadas especificamente nas LPN persistentes da etapa de promoção da hepatocarcinogênese, foi possível identificar que de fato houve dois perfis de resposta biológica distintos: um nos grupos $\mathrm{H}_{2} \mathrm{O}$ e $\mathrm{AF}$ 64, que se demonstraram ligados a eventos inibitórios da carcinogênese como uma menor hipometilação global do DNA e outro nos grupos AF 16 e 32 ligados a eventos que retratam uma possível promoção do processo carcinogênico, entre eles uma maior muliplicidade, número, área e \% da área do corte ocupada pelas LPN GST-P positivas persistentes (Figuras 23 e 24 e Tabela 5).

Desse modo, essa análise demonstra-se não só válida para resumir as informações provenientes de diferentes biomarcadores utilizados para avaliar os efeitos desse composto bioativo (CASTRO et al., 2005), mas também para corroborar e esclarecer o modo de ação do AF, uma vez que mesmo em um modelo de carcinogênese não tão agressivo como o desenvolvido no presente projeto e com o uso de um considerável número de animais, o AF apresentou uma ação dúbia, com tendência à piora do processo em determinadas doses, conforme observado previamente em outros órgãos em estudos como os desenvolvidos por Kim e colaboradores (1996), ainda no período pré-fortificação obrigatória nos países que a adotaram e, posteriormente, por Song e colaboradores (2000 a e b).

Desse modo, os resultados obtidos sugerem cautela acerca dos efeitos distintos e opostos do AF na promoção, como observado também em outros modelos de carcinogênese (BIRD, 1995; KIM et al., 1996; WARGOVICH et al., 1996; SONG et al., 2000 a, b; KIM, 1999, 2006 a e b, 2007; PELLIS et al., 2008) e atenção à política de fortificação obrigatória de determinados alimentos, uma das maiores intervenções de saúde pública dirigidas pela ciência já realizadas e que expôs populações inteiras a elevadas concentrações de AF sintético. 


\section{CONCLUSÃO}

No presente momento ainda considera-se altamente controverso o conhecimento sobre os efeitos do AF no desenvolvimento e progressão da carcinogênese (LINDZON et al., 2009).

Isso se deve ao fato de que havia muitos estudos relatando correlações inversas entre a ingestão de AF da dieta e suas concentrações plasmáticas e o risco de alguns tipos de câncer e, recentemente emergiu uma grande quantidade de evidências que sugerem cautela quanto ao fato de que altas concentrações de AF podem promover a carcinogênese, especialmente diante da presença de LPN (LINDZON et al., 2009).

Tanto quanto se sabe, este é o primeiro estudo a investigar os efeitos do AF na etapa de promoção da hepatocarcinogênese, quando LPN já se encontram estabelecidas no tecido hepático e, embora, não se tenha observados diferenças estatisticamente significantes em parte dos resultados obtidos, os dados, coletivamente (Figuras 22, 23 e 24), suportam a hipótese de que a suplementação com o AF modula a carcinogênese de modo a promover uma indução do processo nas doses de 8 e 16 vezes a RDA e inibição ou retorno ao padrão de hepatocarcinogênese observado no grupo controle $\left(\mathrm{H}_{2} \mathrm{O}\right)$ na dose de 32 vezes a RDA, caracterizando uma curva em formato de sino (Figura 26), como já observados por outros autores em modelos de carcinogênese em órgãos distintos (KOTSOPOULOS et al., 2003; VAN GUELPEN et al., 2006).

Aparentemente, essa ação do AF não foi diretamente modulada pelos mecanismos genéticos e epigenéticos avaliados no presente trabalho. No entanto, fica cada vez mais evidente que o AF pode modular a carcinogênese através de mecanismos distintos como pela modulação do metabolismo da homocisteína e regulação de enzimas de sua via metabólica por mecanismo de “feedback" negativo (conforme sugerido pela sequência de eventos 1-8 da Figura 25). 
Além disso, os resultados obtidos na análise de parâmetros genéticos e epigenéticos de LPN hepáticas microdissecadas também apresentam caráter inédito e contribuem no mesmo sentido de que um estudo recente de hepatocarcinogênese que realiza macrodissecção de lesões e em seguida análise do perfil gênico das mesmas e estabeleceu que de fato essas lesões apresentam características distintas dos tecidos ao seu redor (KAPOSI-NOVAK et al., 2009). Assim, aventa-se que estudos desse gênero possam contribuir para um futuro estabelecimento de perfis genômicos que viabilizem a classificação de LPN e carcinomas.

À luz do exposto e dos resultados obtidos no presente trabalho, é prudente ao menos re-analisar o conceito de que o AF é seguro e puramente benéfico, representando um componente ideal para alimentos funcionais, o que foi um dos pontos favoráveis ao estabelecimento da fortificação.

Afinal, fica cada vez mais claro que a segurança da administração desse composto é dependente da dose e do momento da intervenção e, inclusive, deveria ser considerada a possibilidade de não expor populações inteiras à fortificação em prol de um grupo de risco específico e restrito que estaria suceptível ao desenvolvimento de defeitos no tubo neural, até porque, tudo indica que o efeito da fortificação do AF no risco de câncer apresentará um impacto maior em termos de saúde pública do que a redução da incidência dos defeitos em tubo neural de bebês (KIM, 2004).

Sendo assim, cada vez mais o conceito de que o AF pode proteger contra a carcinogênese em alguns tecidos, mas promover esse processo quando já iniciado, ganha atenção, especialmente porque ainda não se tem domínio acerca dos possíveis efeitos do enriquecimento de alimentos com AF, como já ocorre no Brasil, na incidência do câncer. 


\section{REFERÊNCIAS BIBLIOGRÁFICAS}

AKOGLU, B.; MILOVIC, V.; CASPARY, W. F.; FAUST, D. Hyperproliferation of homocysteine-treated colon cancer cells is reversed by folate and 5-methyltetrahydrofolate. Eur. J. Nutr., v. 43, p. 93-99, 2004.

ALTEKRUSE S. F.; MCGLYNN K. A.; REICHMAN M. E. Hepatocellular carcinoma incidence, mortality, and survival trends in the United States from 1975 to 2005. J. Clin. Oncol., v. 27, n. 9, p. 1485-1491, 2009.

ALYAQOUB, F. S.; TAO, L.; KRAMER, P. M.; STEELE, V. E.; LUBET, R. A.; GUNNING, W. T.; PEREIRA, M. A. Prevention of mouse lung tumors and modulation of DNA methylation by combined treatment with budesonide and R11577 (ZarnestraMT). Carcinogenesis., v. 28, p. 124-129, 2006.

BAGGOTT, J. E.; VAUGHN, W. H.; JULIANA, M. M.; ETO, I.; KRUMDIECK, C. L.; GRUBBS, C. J. Effects of folate deficiency and supplementation on methylnitrosoureainduced rat mammary tumors. J. Natl. Cancer Inst., v. 84, p. 1740-1744, 1992.

BAI, H.; GU, L.; ZHOU, J.; DENG, D. p16 hypermethylation during gastric carcinogenesis of Wistar rats by N-methyl-N'-nitro-N-nitrosoguanidine. Mutat. Res., v. 535, p. 73-78, 2003.

BALAGHI, M.; WAGNER, C. DNA methylation in folate deficiency: use of CpG methylase. Biochem. Biophys. Res. Commun., v. 193, p.1184-1190, 1993.

BANNASCH, P. Pre-neoplastic lesions as end points in carcinogenisis testing. I. Hepatic Preneoplasia. Carcinogenesis, v. 7, p. 689-695, 1986.

BANNASCH, P.; HAERTEL, T.; SU, Q. Significance of hepatic preneoplasia in risk identification and early detection of neoplasia. Toxicol. Pathol, v. 31, p. 134-139, 2003.

BANNASCH, P.; ZERBAN, H. Tumors of the liver. In: TURUSOV, V. S.; MOHR, U. Pathology of Tumors in Laboratory Animals. Lyon: IARC Scientific Publications, v. 1, n. 99, 1990, p. 199-240. 
BARBISAN, L. F.; SCOLASTICI, C.; MIYAMOTO, M.; SALVADORE, D. M.; RIBEIRO, L. R.; DaEIRA, A. F.; CAMARGO, J. L. Effects of crude extracts of Agaricus blazei on DNA damage and rat liver carcinogenesis induced by diethylnitrosamine. Genet. Mol. Res., v. 2, p. 295-308, 2003.

BASHIR, O.; FITZGERALD, A. J.; GOODLAD; R. A. Both suboptimal and elevated vitamin intakes increase intestinal neoplasia and alter crypt fission in the $A p c^{\mathrm{Min} /+}$ mouse. Carcinogenesis, v. 25, n. 8, p. 1507-1515, 2004.

BASTEN, G. P.; DUTHIE, S. J.; PIRIE, L.; VAUGHAN, N.; HILL, M. H.; POWERS, H. J. Sensitivity of markers of DNA stability and DNA repair activity to folate supplementation in healthy volunteers. Br. J. Cancer., v. 94, p.1942-1947, 2006.

BAYLIN, S. B.; HERMAN, J. G.; GRAFF, J. R. Alterations in DNA methylation: a fundamental aspect of neoplasia. Adv. Cancer Res., v. 72, p. 141-196, 1998.

BERTRAM, J. S. The molecular biology of cancer. Mol. Aspects Med., v. 21, p. 167-223, 2000.

BIRD, R. P. Role of aberrant crypt foci in understanding the pathogenesis of colon cancer. Cancer Lett., v. 98, p. 55-71, 1995.

BLOUNT, B. C.; MACK, M. M.; WEHR, C. M.; MacGREGOR, J. T.; HIATT, R. A.; WANG, G.; WICKRAMASINGHE, S. N.; EVERSON, R. B.; AMES, B. N. Folate deficiency causes uracil misincorporation into human DNA and chromosome breakage: implication for cancer and neuronal damage. Proc. Natl. Acad, Sci. USA, v. 94, p. 32903295, 1997.

BOLLHEIMER, L. C.; BUETTNER, R.; KULLMANN, A.; KULLMANN, F. Folate and its preventive potential in colorectal carcinogenesis. How strong is the biological and epidemiological evidence? Critical Reviews in Oncology/Hematology, v. 55, p. 13-36, 2005. 
BULL C.; FENECH M. Genome-health nutrigenomics and nutrigenetics: nutritionl requirements or "nutriomes" chromosomal stability and telomere maintenance at the individual level. Proc. Nutr. Soc., v. 67, n. 2, p. 146-156, 2008.

CALVISI, D. F.; SIMILE, M. M.; LADU, S.; PELLEGRINO, R.; De MURTAS, V.; PINNA, F.; TOMAIS, M. L.; FRAU, M.; VIRDIS, P.; De MIGLIO, M. R.; MURONI, M. R; PASCALE, R. M.; FEO, F. Altered methionine metabolism and global DNA methylation in liver cancer: relationship with genomic instability and prognosis. Int. J. Cancer., v. 121, p. 2410-2420, 2007.

CANISTRO D.; POZZETTI L.; SAPONE A.; BROCCOLI M.; AFFATATO A. A.; STRADIOTTI A.; LONGO V.; MENICHINI P.; BARALE R.; PAOLINI M. Perturbation of murine liver cyp-superfamily of isoforms by different combinations of pesticide mixtures. Food Chem. Toxicol., v. 46, n. 1, p. 34-42, 2007.

CARBONE, M.; KLEIN, G.; GRUBER, J.; WONG, M. Modern criteria to establish human cancer etiology. Cancer Res., v. 64, p. 5518-5524, 2004.

CASTRO, I. A.; BARROSO, L. P.; SINNECKER, O. Functional foods for coronary heart disease risk reduction: a meta-analysis using a multivariate approach. Am. J. Clin. Nutr., v. 82, p. 32-40, 2005.

CERDA, H.; DELINCEE, H.; HAINE, H.; RUPP, H. The DNA “comet assay” as a rapid screening technique to control irradiated food. Mutat. Res, v. 375, p. 167-181, 1997.

CHARLES, D.; NESS, A. R.; CAMPBELL, D.; SMITH, G. D.; HALL, M. H.; Taking folate in pregnancy and risk of maternal breast cancer. B. J. M., v. 329, p. 1375-1346, 2004.

CHEN, H.; LI, S.; LIU, J.; DIWAN, B. A.; BARRET, J. C.; WAALKES, M. P. Chronic inorganic arsenic exposure induces hepatic global and individual gene hypomethylation: implications for arsenic hepatocarcinogenesis. Carcinogenesis, v. 25, p. 1779-1786, 2004. 
CHIARELLO, P. G. et al. Effect of a necrogenic dose of diethylnitrosamine on vitamin Edeficient and vitamin E-supplemented rats. Food and Chemical Toxicology, v. 36, p. 929935, 1998.

CHOI S. W.; MASON J. B. Folate status: effects on pathways of colorectal carcinogenesis. J. Nutr., v. 1332, n. 8, p. 2413S-2418S, 2002.

CHOI, S.W.; MASON, J. B. Folate and carcinogenesis: an integrated scheme. J. Nutr., v. 130, p. 129-132, 2000.

CHOI, S.W.; MASON, J. B. Folate status: effects on pathway of colorectal carcinogenesis. J. Nutr., v. 132 (Suppl.), p. S2413-2418, 2002.

COLE M. D.; COWLING, V. H. Transcription-independent functions of MYC: regulation of translation and DNA replication. Nat. Rev. Mol. Cell. Biol., v. 9, n. 10, p. 810-815, 2008.

COLE, B. F.; BARON, J. A.; SANDLER, R. S.; et al. A randomized trial of folic acid to prevent colorectal adenomas. Proc. Am. Assoc. Cancer Res., v. 46, p. 4399, 2005.

COLE, B. F.; BARON, J. A.; SANDLER, R. S.; HAILE, R. W.; AHNEN, D. J.; BRESALIER, R. S.; KEOWN-EYSSEN, G. M.; SUMMERS, R. W.. ROTHSTEIN, R. I., et al. Folic acid for the prevention of colorectal adenomas: a randomized clinical trial. Jama, v. 297, p. 2351-2359, 2007.

COZZOLINO, S. M. F. Biodisponibilidade de Nutrientes. 2. ed. São Paulo: Manole, 2006, p. 385-399.

CRAVO, M. L.; PINTO, A. G.; CHAVES, P.; CRUZ, J. A.; LAGE, P.; NOBRE LEITAO, C.; COSTA MIRA, F. Effect of folate supplementation on DNA methylation of rectal mucosa in patients with colonic adenomas: correlation with nutrient intake. Clin. Nutr., v. 17, n. 2, p. 45-49, 1998. 
CRAVO, M.; FIDALGO, P.; PEREIRA, A. D.; GOUVEIA-OLIVEIRA, A.; CHAVES, P.; SELHUB, J.; MASON, J. B.; MIRA, F. C.; LEITAO, C. N. DNA methylation as an intermediate biomarker in colorectal cancer: modulation by folic acid supplementation. Eur. J. Cancer Prev., v. 3, p. 473-479, 1994.

CRAVO, M.; GLORIA, L.; SALAZAR DE SOUZA, L.; CHAVES, P. Folate status, DNA methylation and colon cancer risk in inflammatory bowel disease. Clin. Nutr., v. 14, p. 50-53, 1995.

DELAGE, B.; DASHWOOD, R. H. Dietary manipulation of histone structure and function. Annu Rev Nutr. v. 28, p. 347-366, 2008.

DIZIK M.; CHRISTMAN J. K.; WAINFAN E. Alterations in expression and methylation of specific genes in livers of rats fed a cancer promoting methyl-deficient diet. Carcinogenesis, v. 12, n. 7, p. 1307-1312, 1991.

DRAGAN, Y. P.; CAMPBELL, H. A.; XU, X. H.; PITOT, H. C. Quantitative stereological studies of a "selection" protocol of hepatocarcinogenesis following initiation in neonatal male and female rats. Carcinogenesis, v. 18, p. 149-158, 1997.

DUTHIE S. J.; NARAYANAN S.; SHARP L.; LITTLE J.; BASTEN G.; POWERS H. Folate, DNA stability and colo-rectal neoplasia. Proc. Nutr. Soc., v. 63, n. 4, p. 571-578, 2004.

DUTHIE, S. J.; NARAYANAN, S.; BRAND, G. M.; PIRIE, L.; GRANT, G. Impact of folate deficiency on DNA stability. J. Nutr., v. 132, p. 2444S-2449S, 2002.

DUTHIE, S. J.; NARAYANAN, S.; BRAND, M.; GRANT, G. DNA stability and genomic methylation status in colonocytes isolated from methyl donor-deficient rats. Eur. J. Nutr., v. 39, p. 106-111, 2000.

EMANUELE, S.; DÁNNEO, A.; BELLAVIA, G.; VASSALO, B.; LAURICELLA, M.; DE BLASIO, A.; VENTO, R.; TESORIERE, G. Sodium butyrate induces apoptosis in human 
hepatoma cells by a mitochondria/caspase pathway, associated with degradation of $\beta$-catenin, pRb and Bcl-Xl. Eur. J. Cancer, v. 40, p. 1441-1452, 2004.

EMMERT-BUCK, M. R.; BONNER R. F.; SMITH, P. D.; CHUAQUI, R. F.; ZHUANG, Z.; GOLDSTEIN, S. R.; WEISS, R. A.; LIOTTA, L.A. Laser capture microdissection. Science, v. 274, p. 998-1001, 1996.

ESPÍNDOLA, R. M.; MAZZANTINI, R. P.; ONG, T. P.; De CONTI, A.; HEIDOR, R.; MORENO, F.S. Geranylgeraniol and beta-ionone inhibit hepatic preneoplastic lesions, cell proliferation and DNA damage during the initial phases of hepatocarcinogenesis, but only the former inhibits NF-kappaB activation. Carcinogenesis, v. 26, p. 1091-1099, 2005.

ESTELlER, M.; GUO, M.; MORENO, V.; PEINADO, M.A.; CAPELLA, G.; GAIM, O.; BAYLIN, S. B.; HERMAN, J. G. Hypermethylation-associated inactivation of the Cellular Retinol-Binding-Protein 1 gene in human cancer. Cancer Res., v. 62, p. 5902-5905, 2002.

FANG, J.; ZHU, S.; XIAO, S.; SHI, Y.; JIANG, S.; ZHOU, X.; QIAN, L. Alterations of level of total genomic DNA methylation and pattern of c-myc, c-Ha-ras oncogene methylation in humangastric carcinogenesis. Chin. Med. J., v. 109, n. 10, p. 787-791, 1996.

FARBER, E. Cancer development and its natural history. A cancer prevention perspective. Cancer, v. 62, p. 1676-1679, 1988.

FARBER, E. Cell proliferation as a major risk factor for cancer: a concept of doubtful validity. Cancer Res., v. 55, p. 3759-3762, 1995.

FARBER, E.; RUBIN, H. Cellular adaptation in the origin and development of cancer. Cancer Research, v. 51, p. 2751-2761, 1991.

FARBER, E.; SARMA, D. S. Hepatocarcinogenesis: a dynamic cellular perspective. Lab. Invest., v. 56, p. 4-22, 1987. 
FARBER, S. Some observations on the effect of folic acid antagonists on acute leukemia and other forms of incurable cancer. Blood, v. 4, p. 160-167, 1949.

FEI, S. J.; XIAO, S. D.; PENG, Y. S.; CHEN, X. Y; SHI, Y. Chemopreventive effects of rofecoxib and folic acid on gastric carcinogenesis induced by N-methyl-N'-nitro-Nnitrosoguanidine in rats. Chin. J. Dig. Dis., v. 7, p. 134-140, 2006.

FEINBERG, A. P.; GEHRKE, C. W.; KUO, K. C.; EHRLICH, M. Reduced genomic 5methylcitosine content in human colonic neoplasia. Cancer Research, v. 48, p. 1159-1161, 1988.

FEINBERG, A. P.; OHLSSON, R.; HEINKOFF, S. The epigenetic progenitor origin of human cancer. Nature Reviews Genetics, v. 7, p. 21-33, 2006.

FEND, F.; RAFFELD, M. Laser capture microdissection in pathology. J. Clin. Pathol., v. 53, p. 666-672, 2000.

FENECH, M.; AITKEN, C.; RINALDI, J. Folate, vitamin B12, homocystein status and DNA damage in young Australian adults. Carcinogenesis, v. 19, p. 1163-1171, 1998.

FEO, F.; GARCEA, R.; DAINO, L.; PASCALE, R.; PIRISI, L.; FRASSETTO, S.; RUGGIU, M.E. Early stimulation of polyamine biosynthesis during promotion by phenobarbital of diethylnitrosamine-induced rat liver carcinogenesis. The effect of variations of S-adenosyl-Lmethionine cellular pool. Carcinogenesis, v. 6, p. 1713-1720, 1985.

FIGUEIREDO, J. C.; GRAU, M. V.; HAILE, R. W.; SANDLER, R. S.; SUMMERS, R. W.; BRESALIER, R. S.; BURKE, C. A.; McKEOWN-EYSSEN, G. E.; BARON, J. A. Folic acid and risk of prostate cancer: results from a randomized clinical trial. J Natl. Cancer Inst., v. 101, p. 432-435, 2009.

FONSECA, E. M. A. V..; CHAGAS, C. E. A.; MAZZANTINI, R. P.; HEIDOR, R.; ONG, T. P.; MORENO, F. S. All-trans and 9-cis retinoic acids, retinol and beta-carotene 
chemopreventive activities during the initial phases of hepatocarcinogenesis involve distinct actions on glutathione S-transferase positive preneoplastic lesions remodeling and DNA damage. Carcinogenesis, v. 26, 1940-6, 2005.

FU, Y.; DENG, W.; KAWARADA, Y.; KAWAGOE, M.; MA, Y.-Z.; LI, X.; GUO, N.; KAMEDA, T.; TERADA, K.; SUGIYAMA, T. - Mutation and expression of the p53 gene during chemical hepatocarcinogenesis in F344 rats. Biochim. Biophys. Acta., v. 1628, p. 4049, 2003.

GARCEA, R.; DAINO, L.; PASCALE, R.; SIMILE, M. M.; PUDDU, M.; RUGGIU, M. E.; SADDAIU, M. A.; SATTA, G.; SEQUENZA, M. J.; FEO, F. Protooncogene methylation and expression in regenerating liver and preneoplastic liver nodules inducel in the rat by diethylnitrosamine: effects of variations of S-adenosylmethionine:S-adenosylhomocysteine ratio. Carcinogenesis, v. 10, p. 1183-1192, 1989.

GLYNN, S. A.; ALBANES, D. Folate and cancer: a review of the literature. Nutr. Cancer, v. 22, n. 2, p. 101-119, 1994.

GOBE, G.; RUBIN, M.; WILLIAMS, G.; SAWCZUK, I.; BUTTYAN, R. Apoptosis and expression of Bcl-2, Bcl-XL, and Bax in renal cell carcinomas. Cancer Invest., v. 20, p. 324332, 2002.

GOETHEM, F. V.; GHAHROUDI, M. A.; CASTELAIN, P.; KIRSCH-VOLDERS, M. Frequency and DNA content of micronuclei in rat parenchymal liver cells during experimental hepatocarcinogenesis. Carcinogenesis, v. 14, p. 2397-2406, 1993.

GRASL-KRAUPP, B.; BURSCH, W.; RUTTKAY-NEDECKY, B.; WAGNER, A.; LAUER, B.; SHULTE-HERRMANN, R. Food restriction eliminates preneoplastic cells through apoptosis and antagonizes carcinogenesis in rat liver. Proc. Natl. Acad. Sci. USA, v. 91, p. 9995-9999, 1994.

GREENWALD, P. Cancer chemoprevention. B.M.J., v. 324, p. 23, 2002. 
HARSCH, M.; BENDRAT, K.; HOFMEIER, G.; BRANSCHEID, D.; NIENDORF, A. A new method for histological microdissection utilizing an ultrasonically oscillating needle demonstrated by differential mRNA expression in human lung carcinoma tissue. Am. J. Pathol., v. 158, p. 1985-1990, 2001.

HERBET, V. The inhibition and promotion of cancers by folic acid, vitamin B12, and their antagonists. Tenobiotic Metabolism: Nutritional Effects. Am. Chem., p. 31-36, 1985.

HIGGINS, G. M.; ANDERSON, R.M. Experimental pathology of the liver: I. Restoration of the liver of the white rat following partial hepatectomy. Anal. Biochem., v. 12, p. 186-202, 1931.

HIRSCH, S.; SANCHEZ, H.; ALBALA, C.; De la MAZA, M. P.; BARRERA, G.; LEIVA, L.; BUNOUT, D. Colon cancer in Chile before and after the start of the flour fortification program with folic acid. Eur. J. Gastroenterol. Hepatol, v. 21, p. 436-439, 2009.

HSU, S. M.; RAINE, L.; FANGER, H. Use of avidin-biotin-peroxidase complex (ABC) in immunoperoxidase techeniques: a comparison between $\mathrm{ABC}$ and unlabeles antibody (PAP) procedures. J. Histochem. Cytochem., v. 29, p. 577-580, 1981.

HUFF, J. Issues and controversies surrounding qualitative strategies for identifying and forecasting cancer causing agents in the human environment. Pharmacology \& Toxicology, v. 72, p. S12-27, 1993.

IMAI, T.; MASUI, T.; ICHINOSE, M.; NAKANISHI, H.; YANAI, T.; MASEGI, T.; MURAMATSU, M. Reduction of glutathione S-transferase P-form mRNA expression in remodeling nodules in rat liver revealed by in situ hybridization. Carcinogenesis, v. 18, p. 545551, 1997.

ITO, N.; IMAIDA, K.; ASAMOTO, M.; SHIRAI, T. Early detection of carcinogenic substances and modifiers in rats. Mutat. Res., v. 462, p. 209-217, 2000. 
ITTRICH, C.; DEML, E.; OESTERLE, D.; KÜTTLER, K.; MELLERT, W.; BRENDLERSCHWAAB, S.; ENZMANN, H.; SCHLADT, L.; BANNASCH, P.; HAERTEL, T.; MÖNNIKES, O.; SCHWARZ, M.; KOPP-SCHNEIDER, A. Prevalidation of a rat liver foci bioassay (RLFB) based on results from 1600 rats: A Study Report. Toxicol. Pathol., v. 31, p. 60-79, 2003.

JACOB R. A.; GRETZ D. M.; TAYLOR P. C.; JAMES S. J.; POGRIBNY I. P.; MILLER B. J.; HENNING S. M.; SWENDSEID M. E. Moderate folate depletion increases plasma homocysteine and decreases lymphocyte DNA methylation in postmenopausal women. $\mathbf{J}$. Nutr., v. 128, n. 7, p. 1204-1212, 1998.

JAMES S. J.; BASNAKIAN A. G.; MILLER B. J. In vitro folate deficiency induces deoxynucleotide pool imbalance, apoptosis, and mutagenesis in Chinese hamster ovary cells. Cancer Res., v. 54, n. 19, p. 5075-5080, 1994.

JEMAL, A.; SIEGEL, R.; WARD, E.; MURRAY, T.; XU, J.; SMIGAL, C.; THUN M.J. Cancer statistics. CA Cancer J. Clin., v. 56, p. 106-130, 2006.

JIANG, Y. H.; BRESSLER, J.; BEAUDET, A. L. Epigenetics and human disease. Annu Rev. Genomics Hum. Genet., v. 5, p. 479-510, 2004.

JONES, P. A.; BAYLIN, S. B. The epigenomics of cancer. Cell, v. 128, p. 683, 2007.

JONES, P. A.; BAYLIN, S. B. The fundamental role of epigenetics events in cancer. Nat. Rev. Genet., v. 3, p. 415-428, 2002.

JUNQUEIRA; CARNEIRO. Biologia Celular e Molecular. 7. ed. Guanabara Koogan, 2000.

KANAI, Y.; HIROHASHI, S. Alterations of DNA methylation associated with abnormalities of DNA methyltransferases in human cancers during transition from a precancerous to a malignant state. Carcinogenesis v. 28, p. 2434-2442, 2007. 
KANAI, Y.; USHIJIMA, S.; TSUDA, H.; SAKAMOTO, M.; HIROHASHI, S. Aberrant DNA methylation precedes loss of heterozygosity on chromosome 16 in chronic hepatitis and liver cirrhosis. Cancer Letters, v. 148, p. 73-80, 2000.

KAPOSI-NOVAK, P.; LIBBRECHT, L.;WOO, H. G.; LEE, Y. H.; SEARS, N. C.; CONNER, E. A.; FACTOR, V. M.; ROSKAMS, T.; THORGEISSON, S. S. Central role of cmyc during malignant conversion in human hepatocarcinogenesis. Cancer Res., v. 69, p. 2775-2782, 2009.

KHOSRAVIANI, K.; WEIR, H. P.; HAMILTON, P.; MOOREHEAD, J.; WILLIAMSON, K.; Effects of folate supplementation on mucosal cell proliferation in high risk patients for colon cancer. Gut, v. 51, p. 195-199, 2002.

KIM, J. -O.; KIM, H. -N.; HWANG, M. -H.; SHIN, H. -I.; KIM, S.-Y.; PARK, R. -W.; PARK, E. -Y.; KIM, I. -S.; van WIJNEN, A. J.; STEIN, J. L.; LIAN, J. B.; STEIN, G. S.; CHOI, J. -Y. Differential gene expression analysis using paraffin-embedded tissues after laser microdissection. J. Cell. Biochem., v. 90, p. 998-1006, 2003.

KIM, Y. I. Folate: a magic bullet or a double edged sword for colorectal cancer prevention? Gut, v. 55, p. 1387-1389, 2006b.

KIM, Y. I. Does a High Folate Intake Increase the Risk of Breast Cancer? Nutrition Reviews, v. 64 , n. 10 , p. 468-475, 2006a.

KIM, Y. I. Folate and carcinogenesis: Evidence, mechanisms, and implications. J. Nutr. Biochem., v. 10, p. 66-88, 1999.

KIM, Y. I. Folate and colorectal cancer: An evidence-based critical review. Mol. Nutr. Food Res., v. 51, n. 3, p. 267-292, 2007.

KIM, Y. I. Folate, colorectal carcinogenesis, and DNA methylation: lessons from animal studies. Environ. Mol. Mutagen., v. 44, p. 10-25, 2004. 
KIM, Y. I. Role of folate in colon cancer development and progression. J. Nutr., v. 133, p. 3731S-3739, 2003.

KIM, Y. I.; BAIK, H. W.; FAWAZ, K.; KNOX, T.; LEE, Y. M.; NORTON, R.; LIBBY, E.; MANOS, J. B. Effects of folate supplementation on two provisional molecular markers of colon cancer: a prospective, randomized trial. A. J. Gastroenterol., v. 96, p. 184-195, 2001.

KIM, Y. I.; CHRISTIMAN, J. K.; FLEET, J.C. Moderate folate deficiency does not cause global hypomethylation of hepatic and colonic DNA or c-myc-specific hypomethylation of colonic DNA in rats. Am. J. Clin. Nutr., v. 61, p. 1083-1090, 1995.

KIM, Y. I.; POGRBINY, I. P.; BAS NAKIAN, A. G.; MILLER, J. W.; SELHUB, J.; JAMES, S. J.; MASON, J. B. Folate deficiency in rats induces DNA strand breaks and hypomethylation within the p53 tumor suppressor gene. Am. J. Clin. Nutr., v. 65, p. 46-52, 1997.

KIM, Y. I.; SALOMON, R. N.; GRAEME-COOK, F.; CHOI S. W.; SMITH, D. E.; DALLAL, G. E.; MASON, J. B. Dietary folate protects against the development of macroscopic colonic neoplasia in a dose responsive manner in rats. Gut, v. 39, p. 732-740, 1996.

KOMATSU, M.; TSUKAMOTO, I. Effects of folic acid on thymidylate synthase and thymidine kinase in regenerating rat liver after partial hepatectomy. Biochem. Biophys. Acta, v. 2, p. 289-96, 1998.

KOTSOPOULOS, J.; MEDLINE, A.; RENLUND, R.; SOHN, K. J.; MARTIN, R.; HWANG, S. W.; LU, S.; ARCHER, M. C.; KIM, Y. I. Effects of dietary folate on the development and progression of mammary tumors in rats. Carcinogenesis, v. 26, p. 1603-1612, 2005.

KOTSOPOULOS, J.; SOHN, K.-J.; KIM, Y.-I. Postweaning dietary folate deficiency provided through childhood to puberty permanently increases genomic DNA methylation in adult rat liver. The Journal of Nutrition, v. 138, p. 703-709, 2008.

KOTSOPOULOS, J.; SOHN, K.-J.; MARTIN, R.; CHOI, M.; RENLUND, R.; MCKERLIE, C.; HWANG, S. W.; MEDLINE, A.; KIM, Y.-I., Dietary folate deficiency supressses N- 
methyl-N-nitrosurea-induced mammary tumorigenesis in rats, Carcinogenesis, v. 24, n. 3, p. 937-944, 2003.

KRISHNASWAMY, K.; NAIR, K. M. Importance of folate in human nutrition. British Journal of Nutrition, v. 85, n. 2, p S115-S124, 2001.

KUO C. S.; LIN C. Y.; WU M. Y.; LU C. L.; HUANG R. F. Relationship between folate status and tumour progression in patients with hepatocellular carcinoma. Br. J. Nutr., v. 100, n. 3, p. 596-602, 2008.

LACONI, E.; TOMASI, C.; CURRELI, F.; LACONI, S.; SERRA, G.; COLLU, M.; PANI, P. Early exposure to restraint enhances chemical carcinogenesis in rat liver. Cancer Lett., v. 161, p. 215-220, 2000.

LAIRD P. W; JAENISCH R. DNA methylation and cancer. Hum. Mol. Genet., v. 3, p. 1487-1495, 1994.

LARSSON, S. C.; GIOVANNUCCI, E.; WOLK, A. Folate intake, MTHFR polymorphisms, and risk of esophageal, gastric and pancreatic cancer: A meta-analysis. Gastroenterology, v. 131, p. 1271-1283, 2006.

LE LEU, R. K.; YOUNG, G. P.; McINTOSH, G. H. Folate deficiency diminishes the occurrence of aberrant crypt foci in the rat colon but does not alter global DNA methylation status. Journal of Gastroenterology and Hepatology, v. 15, p. 1158-1164, 2000a.

LE LEU, R. K.; YOUNG, G. P.; McINTOSH, G. H. Folate deficiency reduces the development of colorectal cancer in rats. Carcinogenesis, v. 21, n. 12, p. 2261-2265, 2000b.

LEE, B.; SRINIVASAN, M.; AALINKEEL, R.; PATEL, M.S.; LAYCHOCK, S.G. Mitochondrial-encoded gene regulation in rat pancreatic islets. Metabolism, v. 50, p. 200206, 2001.

LEHMAN, N. L.Future potential of thymidylate synthase inhibitors in cancer chemotherapy. Expert Opin. Investig. Drugs., v. 11, p. 1775-1787, 2002. 
LIN J.; LEE I. M.; COOK N. R.; SELHUB, J.; MANSON J. E.; ZHANG, B. J. E. S. M. Plasma folate, vitamin B-6, vitamin B-12, and risk of breast cancer in women. Am. J. Clin. Nutr. v. 87, p. 734-743, 2008.

LINDZON, G. M.; MEDLINE, A.; SOHN, K.-J.; DEPEINT, F.; CROXFORD, R.; KIM, Y-I. Effect of folic acid supplementation on the progression of colorectal aberrant crypt foci. Carcinogenesis., v. 30, n. 9, , p. 1536-1543 , 2009.

LOEB, L. A.; LOEB, K. R.; ANDERSON, J. P. Multiple mutations and cancer. Proc Natl Acad Sci USA., v. 4, p. 776-781, 2003.

LUCH, A. Nature and nurture - lessons from chemical carcinogenesis. Nat. Rev. Cancer, v. 5, p. 113-25, 2005.

LUEBECK E. G.; MOOLGAVKAR S. H.; LIU A. Y.; BOYNTON A.; ULRICH C. M. Does folic acid supplementation prevent or promote colorectal cancer? Results from model-based predictions. Cancer Epidemiol. Biomarkers Prev., v. 17, n. 6, p. 1360-1367, 2008.

MAGGIONI, M.; COGGI, G.; CASSANI, B.; BIANCHI, P.; ROMAGNOLI, S.; MANDELLI, A.; BORZIO, M.; COLOMBO, P.; RONCALLI, M. Molecular changes in hepatocellular dysplastic nodules on microdissected liver biopsies. Hepatology, v. 32, p. 942-946, 2000.

MARRERO, J. A.; PELletiER, S. Hepatocellular Carcinoma. Clin. Liver Dis., v. 10, p. 339-351, 2006.

MARTEL, J. H. I. ; FERRAUDO, A. ; MÔRO, J. R. ; PERECIN, D. Estatística Multivariada na discriminação de raças amazônicas de pupunheiras (Bactris gasipaes Kunth) em Manaus (Brasil). Rev. Bras. Frutic., v. 25, n. 1, p. 115-118, 2003.

MARTINEZ, G. R.; LOUREIRO, A. P. M.; MARQUES, S. A.; MIYAMOTO, S.; YAMAGUCHI, L. F.; ONUKI, J.; ALMEIDA, E. A.; GARCIA, C. C. M.; BARBOSA, L. F.; MEDEIROS, M. H. G.; DI MASCIO, P. Oxidative and alkylating damage in DNA. Mutat. Res., v. 544, p. 115-127, 2003. 
MASON, J. B.; DICKSTEIN, A.; JACQUES, P. F.; HAGGARTY, P.; SELHUB, J.; DALLAL, G.; ROSENBERG, I. H., A temporal association between folic acid fortification and an increase in colorectal cancer rates may be illuminating important biological principles: a hypothesis. Cancer Epidemiol. Biomarkers. Prev., v. 16, p. 1325-1329, 2007.

MAZZANTINI, R. P.; DE CONTI, A.; MORENO, F. S. Persistent and remodeling hepatic preneoplastic lesions present differences in cell proliferation and apoptosis, as well as in p53, Bcl-2 and NF-кB pathways. J. Cell. Biochem. v. 103, p. 538-46, 2008.

MCNUlty, H.; PENTIEVA, K. Folate bioavailability. Proceedings of the Nutrition Society, v. 63, p. 529-536, 2004.

\section{MINISTÉRIO DA SAÚDE-INSTITUTO NACIONAL DO CÂNCER (INCA).}

Estimativas da incidência e mortalidade por câncer. INCA, Rio de Janeiro, 2003, 92p.

MINISTÉRIO DA SAÚDE-INSTITUTO NACIONAL DO CÂNCER (INCA). Vigilância do Câncer: Estimativa 2006: Incidência de câncer no Brasil. INCA, Rio de Janeiro, 2006, 98 p.

MORENO, F. S.; RIZZI, M. B.; DAGLI, M. L.; PENTEADO, M. V. Inhibitory effects of betacarotene on preneoplastic lesions induced in Wistar rats by the resistant hepatocyte model. Carcinogenesis, v. 12, p. 1817-1822, 1991.

MORENO, F. S.; S-WU, T.; NAVES, M. M.; SILVEIRA, E. R.; OLORIS, S. C.; da COSTA, M. A.; DAGLI, M. L.; ONG, T. P. Inhibitory effects of beta-carotene and vitamin A during the progression phase of hepatocarcinogenesis involve inhibition of cell proliferation but not alterations in DNA methylation. Nutr. Cancer, v. 44, p. 80-88, 2002.

NIJHOUT, H. F.; REED, M. C.; BUDU, P.; ULRICH, C. M. A mathematical model of the collate cycle. The Journal of Biological Chemistry, v. 279, n. 53, p. 55008-55016, 2004. 
OLIVE, P. L.; BANÁTH, J. P.; DURAND, R. E. Heterogeneity in radiation-induced DNA damage and repair in tumor and normal cells measured using the 'comet' assay. Radiation Research, v. 122, p. 8-94, 1990.

OLIVEIRA, V.; MAZZANTINI, R. P.; ONG, T. P.; JORDÃO Jr, A. A.; VANNUCCHI, H.; DAGLI, M. L. Z.; MORENO, F. S. Absence of inhibitory effects of phenylacetate on preneoplastic lesions induced in Wistar rats by the resistant hepatocyte model of hepatocarcinogenesis. Int. J. Med. Biol. Envirol., v. 29, p. 179-184, 2001.

OMS. Global strategy on diet, physical activity and health. WHO, 2006.

ONG, T. P.; HEIDOR, R.; de CONTI, A.; DAGLI, M. L.; MORENO, F. S. Farnesol and geraniol chemopreventive activities during the initial phases of hepatocarcinogenesis involve similar actions on cell proliferation and DNA damage, but distinct actions on apoptosis, plasma cholesterol and HMGCoA reductase. Carcinogenesis, v. 27, p. 1194-1203, 2006.

PAN, M.-H.; GHAI, G.; HO, C.-T. Food bioactives apoptosis, and cancer. Mol. Food Res., v. 52, p. 43-52, 2008.

PARMIGIANI, R. B.; CAMARGO, A. A. O genoma humano e o câncer. In: FERREIRA, C. G.; ROCHA, J. C. Oncologia Molecular. São Paulo: Atheneu, 2004.

PASCALE, R. M.; DeMIGLIO, M. R.; MURONI, M. R.; SIMILE, M. M.; DAINO, L.; et al. cmyc amplification in pré-malignant and malignant lesions induced in rat liver by resistant hepatocyte model. Int. J. Cancer., v. 68, p. 136-142, 1996.

PASCALE, R. M.; SIMILE, M. M.; DeMIGLIO, M. R.; FEO, F. Chemoprevention of hepatocarcinogenesis: S-adenosyl-L-methionine. Alcohol, v. 27, p. 1993-1998, 2002.

PASCALE, R. M.; SIMILE, M. M.; DeMIGLIO, M. R.; NUFRIS, A.; DAINO, L.; SADDAIU, M.A.; RAO, P. M.; RAJALAKSMI, S.; SARMA, D. S.; FEO, F. Chemoprevention by Sadenosyl-L-methionine of rat liver carcinogenesis initiated by 1,2-dimethylhydrazine and promoted by orotic acid. Carcinogenesis, v. 16, p. 427-430, 1995. 
PELLIS L.; DOMMELS Y.; VENEMA D.; POLANEN A.; LIPS E.; BAYKUS H.; KOK F.; KAMPMAN E.; KEIJER J. High folic acid increases cell turnover and lowers differentiation and iron content in human HT29 colon cancer cells. Br. J. Nutr., v. 99, n. 4, p. 703-708, 2008.

PÉREZ-CARREÓN, J. I.; LÓPEZ-GARCÍA, C.; FATTEL-FAZENDA, S.; ARCE-POPOCA, E.; ALEMÁN-LAZARINI, L.; HERNÁNDEZ-GARCÍA, S.; LE BERRE, V.; SOKOL, S.; FRANCOIS, J. M.; VILLA-TREVIÑO, S. Gene expression profile related to the progression of preneoplastic nodules toward hepatocellular carcinoma in rats. Neoplasia, v. 8, p. 373-383, 2006.

PIGGOTT J. R. ; SHARMAN, K. Methods to aid interpretation of multidimensional dada. In : Piggott JR, ed. Statistical procedures in food research. New York, NY : Elsevier Science Publishing Co, 1986 : 181-233.

PITOT, H.C. Animal models of neoplastic development. Dev. Biol. (Basel), v. 106, p. 53-57, 2001.

POGRIBNY, I. P.; BASNAKIAN, A. G.; MILLER, B. J.; LOPATINA, N. G.; POIRIER, L. A.; JAMES, S. J. Breaks in genomic DNA and within the p53 gene are associated with hypomethylation in livers of folate/methyl-deficient rats. Cancer Res., v. 55, p. 1894-1901, 1995.

POGRIBNY, I. P.; BELAND F. A. DNA hypomethylation in the origin and pathogenesis of human diseases. Cell Mol. Life Sci., v., p., 2009.

POGRIBNY, I. P.; JAMES, S. J.; JERNIGAN, S.; POGRIBNA, M. Genomic hypomethylation is specific for preneoplastic liver in folate/methyl deficient rats and does notn occur in nontarget tissues. Mutat. Res., v. 548, p. 53-59, 2004.

POGRIBNY, I. P.; ROSS, S. A.; WISE, C.; POGRIBNA, M.; JONES, E. A.; TRYNDYAK, V. P.; JAMES, S. J.; DRAGAN, Y. P.; POIRIER, L. A., Irreversible global DNA hypomethylation as a key step in hepatocarcinogenesis induced by dietary methyl deficiency. Mutat. Res., v. 593, p. 80-87, 2006. 
POIRIER, L.A. The effect of diet, genetics and chemical on toxicity and aberrant DNA methylation: an introduction. J. Nutr., v. 132, p. 2336S-2339S, 2002.

PUfUletTe, M.; AL-GHNANIEM, R.; KHUSHAL, A.; APPLEBY, P.; HARRIS, N.; GOUT, S.; EMERY, P. W.; SANDERS, T. A. Effect of folic acid supplementation on genomic DNA methylation in patients with colorectal adenoma. Gut, v. 2005, n. 54, p. 648653, 2005.

RADIMER, K.; BINDEWALD, B.; HUGHES, J.; ERVINS, B.; SWANSON, C.; PICCIANO, M. F. Dietary supplement use by US adults: data from the National Health and Nutrition Examination Survey 1999-2000. Am. J. Epidemiol., v. 160, p. 339-349, 2004.

RAMPERSAUD G. C.; BAILEY L. B.; KAUWELL G. P. Relationship of folate to colorectal and cervical cancer: review and recommendations for practitioners. J. Am. Diet Assoc., v. 102, n. 9, p. 1273-1282, 2002.

REDDY, B. S.; WANG, C. X.; ALIAGA, C.; RAO, C. V.; LUBET, R. A.; STEELE, V. E.; KELLOFF, G. J. Potential chemopreventive activity of perillyl alcohol and enhancement of experimental colon carcinogenesis by folic acid and genistein. Proc. Am. Assoc. Cancer Res., v. 37, A1849, 1996.

REEVES, P. G.; NIELSEN, F. H.; FAHEY, G. C. Jr. AIN-93 purified diets for laboratory rodents: final report of the American Institute of Nutrition ad hoc writing committee on the reformulation of the AIN-76A rodent diet. J. Nutr., v. 123, p. 1939-1951, 1993.

ROBERTSON, K. D.; JONES, P. A. DNA methylation: past, present and future directions. Carcinogenesis, v. 21, p. 461-467, 2000.

ROBIEN K.; ULRICH C. M. 5,10-Methylenetetrahydrofolate reductase polymorphisms and leukemia risk: a HuGE minireview. Am. J. Epidemiol. , v. 157, n. 7, p. 571-582, 2003. 
ROOMI, M. W.; KO, R. H.; SARMA, D. S. R.; FARBER, E. A common biochemical pattern in preneoplastic hepatocyte nodules generated in four different models in the rat. Cancer Res., v. 45, p. 564-571, 1985.

ROSENBERG I. H. Science-based micronutrient fortification: which nutrients, how much, and how to know? Am. J. Clin. Nutr., v. 82, p. 279-280, 2005.

ROSS, S.A. Diet and DNA methylation interactions in cancer prevention. Ann N Y Acad. Sci., v. 983, p. 197-207, 2003.

SEMPLE-ROBERTS, E.; HAYES, M. A.; AMSTRONG D.; BECKER, R. A.; RACZ, W. J.; FARBER, E. Alternative methods of selecting rat hepatocellular nodules resistant to 2-acetylaminofluorene. Int. J. Cancer, v. 40, p. 643-645, 1987.

SHEN L.; FANG J.; QIU D.; ZHANG T.; YANG J.; CHEN S.; XIAO S. Correlation between DNA methylation and pathological changes in human hepatocellular carcinoma. Hepatogastroenterology, v. 45, n. 23, p. 1753-1759, 1998.

SICHIERI, R.; EVERHART, J. E.; MENDONÇA, J. A. S. Diet and mortality from common cancers in Brazil: an ecological study. Cad. Saúde Públ., v. 12, p. 53-59, 1996.

SIE, K. K. Y.; CHEN, J.; SOHN, K-J.; CROXFORD, R.; THOMPSON, L. U.; KIM, Y.-I. Folic acid supplementation provided in utero and during lactation reduces the number of terminal end buds of the developing mammary glands in the offspring. Cancer Letters, v. 208, p. 72-77, 2009.

SIMILE, M. M.; PAGNAN, G.; PASTORINO, F.; BRIGNOLE, C.; De MIGLIO, M. R.; MURONI, M. R.; ASARA, G.; FRAU, M.; SADDAIU, M. A.; CALVISI, D. F.; FEO, F.; PONZONI, M.; PASCALE, R. M. Chemopreventive N-(4-hydroxyphenyl)retinamide (fenretinide) targets deregulated NF-\{kappa $\} \mathrm{B}$ and Mat1A genes in the early stages of rat liver carcinogenesis. Carcinogenesis, v. 26, p. 417-427, 2005. 
SIMILE, M. M.; PASCALE, R.; De MIGLIO, M. R.; NUFRIS, A.; DAINO, L.; SADDAIU, M. A.; GASPA, L.; FEO, F. Correlation between S-adenosyl-L-methyonine content and production of c-myc, c-Ha-ras, and c-Ki-ras mRNA transcripts in the early stages of rat liver carcinogenesis. Cancer Lett., v. 29, p. 9-16, 1994.

SIMILE, M. M.; SAVIOZZI, M.; DeMIGLIO, M. R.; MURONI, M. R.; NUFRIS, A.; PASCALE, R. M.; MALVALDI, G.; FEO, F. Persistant chemopreventive effect of S-adenosylL-methionine on the development of liver putative preneoplastic lesions induced by thibenzamide in diethylnitrosamine-initiated rats. Carcinogenesis, v. 19, p. 1533-1537, 1996.

SMITH, A. D.; KIM, Y. I.; REFSUM, H. Is folic acid good for everyone? Am. J. Clin. Nutr., v. 87, p. 517-533, 2008.

SOHN, K. J.; STEMPAK, J. M.; REID, S., SHIRWADKAR, S.; MASON, J. B.; KIM, Y. I. The effect of dietary folate on genomic and p-53 specific DNA methylation in rat colon. Carcinogenesis, v. 24, n. 1, p. 81-90, 2003.

SOLT, D.; FARBER, E. New principles for the analysis of chemical carcinogenesis. Nature, v. 263, p. 701-703, 1976.

SONG, J.; MEDLINE, A.; MASON, J. B.; GALLINGER, S.; KIM, Y. I. Effects of dietary folate on intestinal tumorigenesis in the $A p c^{\mathrm{Min}}$ mouse. Cancer Research, v. 60, p. 5434-5440, 2000b.

SONG, J.; SOHN, K. J.; MEDLINE, A.; ASH, C.; GALLINGER, S.; KIM, Y. I. Chemopreventive effects of dietary folate on intestinal polyps in Apc+/-Msh-/- mice. Cancer Research, v. 60, p. 3191-3199, 2000a.

STANGER, O. Physiology of folic acid in health and disease. Current Drug Metabolism, v. 3, p. 211-223, 2002.

STATISTICA 8.0 for Windows, v. 1. Tulsa, OK: StatSoft Inc. Software, 2007. 
STINCHCOMBE, S.; BUCHMANN, A.; BOCK, K. W.; SCHWARZ, M. Inhibition of apoptosis during 2,3,7,8-tetrachlorodibenzo-p-dioxin-mediated tumour promotion in rat liver. Carcinogenesis, v. 16, p. 1271-1275, 1995.

STOLZENBERG-SOLOMON, R. Z.; CHANG, S-C.; LEITZMANN, M. F.; JOHNSON, K. A.; JOHNSON, C.; BUYS, S. S.; HOOVER, R. N.; ZIEGLER, R. G. Folate intake, alcohol use, and postmenopausal breast cancer risk in the prostate, lung, colorectal, and ovarian cancer screening trial. Am. J. Clin. Nutr., v. 83, p. 895-904, 2006.

SU, Q.; BANNASCH, P. Relevance of hepatic preneoplasia for human hepatocarcinogenesis. Toxicol. Pathol., v. 31, p. 126-133, 2003.

SWEENEY, M. R.; MCPARTLIN, J.; SCOTT, J. Folic acid fortification and public health: report on threshold doses above which unmetabolised folic acid appear in serum. BCM Public Health, v. 7, n. 41, p. 1-7, 2007.

TAO, T.; WANG, W.; KRAMER, P. M.; LUBET, R. A.; STEELE, V. E.; PEREIRA, M. A. Modulations of DNA hypomethylation as a surrogate endpoint biomarker for chemoprevcention of colon cancer. Molecular Carcinogenesis, v. 39, p. 79-84, 2004.

TATEMATSU, M.; NAGAMINE, Y.; FARBER, E. Redifferentiation as a basis for remodeling of carcinogen-induced hepatocyte nodules to normal appearing liver. Cancer Res., v. 43, p. 5049-5058, 1983.

THOMADAKI, H.; TALIERI, M.; SCORILAS, A. Prognostic value of the apoptosis related genes BCL2 and BCL2L12 in breast cancer. Cancer Lett., v. 27, 2006.

TOLEDO, L. P.; ONG, T. P.; PINHO, A. L.; JORDÃO Jr, A. A.; VANNUCCHI, H.; MORENO, F.;S. Inhibitory effects of lutein and lycopene on placental glutathione Stransferase-positive preneoplastic lesions and DNA strand breakage induced in Wistar rats by the resistant hepatocyte model of hepatocarcinogenesis. Nutr. Cancer., v. 47, p. 62-69, 2003.

TRAVIS, C. C.; BELEFANT, H. Promotion as a factor in carcinogenesis. Toxicology Letters, v.60, p.1-9, 1992. 
TROEN, A. M.; MITCHELL, B.; SORENSEN, B.; WENER, M. H.; JOHNSTON, A.; WOOD, B.; SELHUB, J.; MC TIERNAN, A.; YASUI, Y.; ORAL, E.; POTTER, J. D.; ULRICH, C. M. Unmetabolized folic acid in plasma is associated with reduced natural killer cell cytotoxicity among postmenopausal women. J. Nutr., v. 136, p. 189-194, 2006.

TRYNDYAK, V. P.; MUSKHELISHVILI, L.; KOVALCHUK, O.; RODRIGUEZ-JUAREZ, R.; MONTGONERY, B.; CHURCHWELL, M. I.; ROSS, S. A.; BELAND, F.A.; POGRIBNY, I. P. Effect of long-term tamoxifen exposure on genotoxic and epigenetic changes in rat liver: implications for tamoxifen-induced hepatocarcinogenesis. Carcinogenesis, v. 27, p. 1713-1720, 2006.

ULRICH, C. M. Nutrigenomics in cancer research-folate metabolism and colorectal cancer. J. Nutr., v. 135, p. 2698-2702, 2005.

ULRICH, C. M.; POTTER, J. D. Folate supplementation: too much of a good thing. Cancer Epidemiol. Biomarkers Prev., v. 15, n. 2, p. 189-193, 2006.

VAN DEN DONK, M.; PELLIS, L.; CROTT, J. W.; VAN ENGELAND, M.; FRIEDERICH, P.; NAGENGAST, F. M.; VAN VERGEIJK, J. D.; BOER, S. Y.; MASON, J. B.; KOK, F. J., KEIJER, J.; KAMPMAN, E. Folic acid and vitamin B-12 supplementation does not favorably influence uracil incorporation and promoter methylation in rectal mucosa DNA of subjects with previous colorectal adenomas. The Journal of Nutrition, v. 137, p. 2114-2120, 2007.

VAN GUELPEN, B.; HULTDIN, J.; JOHANSSON, I.; HALLMANS, G.; STENLING, R.; RIBOLI, E.; WINKVIST, A.; PALMQVIST, R. Low folate levels may protect against colorectal cancer. Gut, v. 55, p. 1461-1466, 2006.

WARGOVICH, M. J.; CHEN, C. D.; JIMENEZ, A.; STEELE, V. E.; VELASCO, M.; STEPHENS, L. C.; PRICE, R.; GRAY, K.; KELLOFF, G. J. Aberrant crypts as a biomarker for colon cancer: evaluation of potential chemopreventive agents in the rat. Cancer Epidemiology, Biomarkers \& Prevention, v. 5, p. 355-360, 1996. 
WATANABE, J.; KUSHIHATA, F.; HONDA, K.; MOMINOK, K.; MATSUDA, S.; KOBAYASHI, N. Bcl-xL overexpression in human hepatocellular carcinoma. Int. J. Oncol., v. 21, p. 515-519, 2002.

WATTENBERG, L.W. Chemoprevention of cancer. Cancer Res., v. 45, p. 1-8, 1985.

WILKINSON, E. - World cancer report. Lancet Oncology, v. 4, p. 321, 2003.

WONG C. M.; NG I. O. Molecular pathogenesis of hepatocellular carcinoma. Liver Int., v. 28, n. 2, p. 160-174, 2008.

WOOD, G. A.; SARMA, D. S.; ARCHER, M. C. Resistance to the promotion of glutathione S-transferase 7-7-positive liver lesions in Copenhagen rats. Carcinogenesis, v. 20, p. 11691175, 1999.

WORM, J.; GULDBERG, P. DNA methylation: an epigenetic pathway to cancer and a promising target for anticancer therapy. J. Oral Pathol. Med., v. 31, p. 443-449, 2002.

WRIGHT, A. J.; DAINTY, J. R.; FINGLAS, P. M. Folic acid metabolism in human subjects revised: potential implications for proposed mandatory folic acid fortification in the UK. Br. J. Nutr., v. 98, p. 667-675, 2007.

WUNSCH FILHO V.; MONCAU J. E. Cancer mortality in Brazil 1980-1995: regional patterns and time trends. Rev. Assoc. Med. Bras., v. 48, n. 3, p. 250-257, 2002. YOO, J. S. H; GUEGERICH, F. P.; YANG, C. S. Metabolism of n-nitrosodialkylamines by human liver microssomes. Cancer Research, v. 48, p.1499-1504, 1988.

YOUNG, M. R.; YANG, H-S.; COLBURN, N. H. Promising molecular targets for cancer prevention: AP-1, NF-kB and Pdcd4. Trends in Molec. Med., v. 9, p. 36-41, 2003. 
ANEXO I - Resolug̣ão RDC No 344

RESOLUÇÃO - RDC Nº 344, DE 13 DE DEZEMBRO DE 2002

O Diretor-Presidente da Agência Nacional de Vigilância Sanitária no uso da atribuição que the confere o inciso IV do art. 13 do Regulamento da ANVISA aprovado pelo Decreto $n^{\circ}$ 3.029 , de 16 de abril de 1999 ,

considerando a necessidade de constante aperfeiçoamento das ações de prevenção e controle sanitário na área de alimentos, visando ả saúde da população;

considerando as recomendações da Organização Mundial da Saúde-OMS e Organização Panamericana da Saúde-OPAS de fortificação de produtos alimentícios com ferro e ácido fólico;

considerando as atribuições emanadas da Comissão Interinstitucional de Condução e Implementação das Ações de Fortificação de Farinhas de Trigo e Farinhas de Milho, coordenada pelo Ministério da Saúde:

considerando os beneficios que advém da prática de adoção de fortificação de farinhas, conforme comprovados em estudos científicos;

considerando que a anemia ferropriva representa um problema nutricional importante no Brasil, com severas consequêencias econômicas e sociais;

considerando que o ácido fólico reduz o risco de patologias do tubo neural e da

mielomeningocele;

considerando que as farinhas de trigo e as farinhas de milho são largamente consumidas pela população brasileira;

considerando a urgência do assunto,

adoto, ad referendum, a seguinte Resolução de Diretoria Colegiada e determino a sua publicação:

Art. $1^{\circ}$ Aprovar o Regulamento Técnico para a Fortificação das Farinhas de Trigo e das Farinhas de Milho com Ferro e Ácido Fólico, constante do anexo desta Resolução.

Art. $2^{\circ}$ As empresas têm o prazo de 18 (dezoito) meses a contar da data de publicação deste Regulamento para adequação de seus produtos.

Art. $3^{\circ} \mathrm{O}$ descumprimento aos termos desta Resolução constitui infração sanitária sujeitando os infratores às penalidades previstas na Lei $a^{\circ}{ }^{\circ} 6.437$, de 20 de agosto de $1977 \mathrm{e}$ demais disposições aplicáveis.

Art. $4^{\circ}$ Fica revogada a Resolução - RDC $n^{\circ} 15$, de 21 de fevereiro de 2000 , DOU de 25 de fevereiro de 2000.

Art. $4^{\circ}$ Esta Resolução entra em vigor na data de sua publicação.

GONZALO VECINA NETO

ANEXO

Regulamento Técnico para Fortificação das Farinhas de Trigo e das Farinhas de Milho com Ferro e Ácido Fólico

1. ALCANCE

1.1. Objetivo

Tornar obrigatória a fortificação das farinhas de trigo e das farinhas de milho com ferro e ácido fólico. 
3.13. BRASIL. Portaria - MS n ${ }^{\circ} 291$, de 08 de fevereiro de 2002 . Inclui no art. $2^{\circ}$ da Portaria $\mathbf{n}^{\circ} 14 \mathrm{MS} / \mathrm{GM}$. Diário Oficial da União, Brasília, 13 de fevereiro de 2002. 3.14. Manual de fortificação de farinha de trigo com ferro. Rio de Janeiro: Embrapa Agroindústria de Alimentos, 2001, 56p. Documentos, ISSN 0103-6068; 46.

3.15. Manual de fortificação de fubá e flocos de milho com ferro. Rio de Janeiro: Embrapa Agroindústria de Alimentos, 2001, 56p. Documentos, ISSN 0103-6068; 47.

3.16. BRASIL. Portaria - MS n 710 , de 10 de junho de 1999. Aprova a Política Nacional de Alimentação e Nutrição. Diário Oficial da União, Brasília, 11 de junho de 1999.

3.17. BRASIL. Resolução CNNPA no 12 de 1978. Aprova os Padrões de Identidade e Qualidade para os alimentos (e bebidas) constantes desta Resolução. Diário Oficial da União, Brasilia, 24 de julho de 1978.

3.18. The Prevention of Neural Tube Defects with Folic Acid. Pan American Health Organization / Word Health Organization, Division of Health Promotion and Protection, Food and Nutrition Program. Centers for Disease Control and Prevention, Birth Defects and Pediatric Genetics- CDC. p. 5-15.

3.19. Iron Fortification: Where Are We in Terms of Iron Compounds a PAHO/FNP/USAID Techinical Consultation. Nutrition Reviews, v. 60, n. 7 (part II), jul. 2002. 61p.

4. PRINCÍPIOS GERAIS

4.1. É obrigatória a adição de ferro e de ácido fólico nas farinhas de trigo e nas farinhas de milho pré-embaladas na ausência do cliente e prontas para oferta ao consumidor, as destinadas ao uso industrial, incluindo as de panificação $\mathbf{e}$ as farinhas adicionadas nas prémisturas, devendo cada $100 \mathrm{~g}$ de farinha de trigo e de farinha de milho fornecerem no mínimo 4,2 $\mathrm{mg}$ (quatro vírgula dois miligramas) de ferro e $150 \mathrm{mcg}$ (cento e cinqüenta microgramas) de ácido fólico.

4.2. As farinhas de trigo e as farinhas de milho fortificadas utilizadas como ingredientes em produtos alimentícios industrializados, onde comprovadamente o ferro e ou ácido fólico causem interferências, poderão ser isentas da adição de ferro e ou ácido fólico. A empresa deve manter a disposição do Órgão de Vigilância Sanitária, os estudos que comprovem essa interferência.

4.3. A escolha dos compostos de ferro para fortificação é de responsabilidade das indústrias, que devem garantir a estabilidade destes nas farinhas de trigo e nas farinhas de milho dentro dos prazos de validade das mesmas.

4.4. As empresas devem assegurar que os compostos de ferro de grau alimentício sejam biodisponiveis.

4.5. As empresas poderão utilizar os seguintes compostos de ferro de grau alimentício: sulfato ferroso desidratado (seco); fumarato ferroso; ferro reduzido - 325 mesh Tyler; ferro eletrolítico - 325 mesh Tyler; EDTA de ferro e sódio (NaFeEDTA); e ferro bisglicina quelato.

Podem ser usados outros compostos desde que a biodisponibilidade não seja inferior a dos compostos listados.

4.6. As empresas deverão utilizar o ácido fólico de grau alimentício, garantindo a estabilidade deste nas farinhas de trigo e nas farinhas de milho dentro do prazo de validade das mesmas.

5. ROTULAGEM

5.1. As farinhas de trigo e as farinhas de milho devem ser designadas usando-se o nome convencional do produto de acordo com a legislação específica, seguido de uma das 
1.2. Âmbito de Aplicaçăo

$O$ presente Regulamento Técnico se aplica a obrigatoriedade da fortificação das farinhas de trigo e das farinhas de milho com ferro e ácido fólico. Excluem-se deste Regulamento, devido a limitações de processamento tecnológico, os seguintes produtos: farinha de bijú ou farinha de milho obtida por maceração; flocão; farinha de trigo integral e farinha de trigo durum. 2. DEFINIÇÕES

2.1. Para efeito deste Regulamento Técnico entende-se por farinhas de milho: os fubás e os flocos de milho.

3. REFERÊNCIAS

3.1. BRASIL. Decreto-Lei n 986 , de 12 de outubro de 1969. Institui Normas Básicas sobre alimentos. Diário Oficial da União, Brasília, 21 de outubro de 1996.

3.2. BRASIL. Portaria SVS/MS nº 540, de 27 de outubro de 1997. Aprova o Regulamento Técnico: Aditivos Alimentares - Definições, Classificação e Emprego. Diário Oficial da União, Brasília, 28 de outubro de 1997.

3.3. BRASIL. Portaria SVS/MS n 27, de 14 de janeiro de 1998. Regulamento Técnico referente à Informação Nutricional Complementar. Diário Oficial da União, Brasília 16 de janeiro de 1998.

3.4. BRASIL. Portaria SVS/MS n 31, de 13 de janeiro de 1998. Regulamento Técnico para Fixação de Identidade e Qualidade de Alimentos Adicionados de Nutrientes Essenciais. Diário Oficial da União, Brasília, 30 de março de 1998.

3.5. BRASIL. Portaria SVS/MS n 33, de 13 de janeiro de 1998. Tabelas de Ingestão Diária Recomendada DR. Diário Oficial da União, Brasilia, 16 de janeiro de 1998.

3.6. BRASIL. Portaria SVS/MS n 42, de 14 de janeiro de 1998. Regulamento Técnico para Rotulagem de Alimentos Embalados. Diário oficial da União, Brasília, 16 de janeiro de 1998.

3.7. BRASIL. Resolução $n^{\circ} 23$, de 15 de março de 2000 . Regulamento Técnico sobre o Manual de Procedimentos Básicos para o Registro e Dispensa da Obrigatoriedade de Registro de Produtos Pertinentes à Área de Alimentos. Diário Oficial da União, Brasília, 16 de março de 2000.

3.8. BRASIL. Resolução- $\operatorname{RDC~n}^{\circ} 39$, de 21 de março de 2001. Tabela de Valores de Referência para Porções de Alimentos e Bebidas Embalados para fins de Rotulagem Nutricional. Diário oficial da União, Brasilia, 22 de março de 2001.

3.9. BRASIL. Resolução- $R D C \mathbf{n}^{\circ} 40$, de 21 de março de 2001. Regulamento Técnico para Rotulagem Nutricional Obrigatónia de Alimentos e Bebidas Embalados. Diário Oficial da União, Brasília, 22 de março de 2001.

3.10. BRASIL. Resolução $\mathrm{n}^{\circ} 385$, de 05 de agosto de 1999. Regulamento Técnico que Aprova o uso de Aditivos Alimentares, estabelecendo suas funções e seus Limites Máximos para a Categoria de Alimentos 6-Cereais e Produtos de ou a Base de Cereais. Diário Oficial da União, Brasília, 09 de agosto de 1999.

3.11. ATA da I Reunião Ordinária da Comissão Interinstitucional de Condução e Implementação das Af̧ões de Fottificação de Farinhas de Trigo e de Milho e seus Subprodutos. Brasília, 19 de Abril de 2002. Documento digitado.

3.12. BRASLl. Portaria - MS/GM n $n^{\circ} 14$, de 03 de janeiro de 2002. Institui a Comissão insterinstitucional de Condução e Implementação das Ações de Fortificação de Farinhas de Trigo e de Milho e seus Subprodutos. Diário Oficial da União, Brasilia, 08 de janeiro de 2002 . 
seguintes expressões: fortificada(o) com ferro e ácido fólico ou enriquecida(o) com ferro e ácido fólico ou rica(o) com ferro e ácido fólico.

5.2. As farinhas de trigo e as farinhas de milho fortificadas usadas como ingredientes deverão ser declaradas na lista de ingredientes da rotulagem com as seguintes expressões: farinha de trigo fortificada ou enriquecida ou rica com ferro e ácido fólico; e farinha de milho fortificada ou enriquecida ou rica com ferro e ácido fólico.

5.3. Os produtos processados que contém como ingrediente as farirhas de trigo e ou as farinhas de milho fortificadas com ferro e ácido fólico e queiram usar as denominações citadas no item anterior, devem atender as disposições estabelecidas no Regulamento Técnico para Fixação de Identidade e Qualidade de Alimentos Adicionados de Nutrientes Essenciais.

6. ADITIVOS

É permitida a utilização dos aditivos alimentares e coadjuvantes de tecnologia previstos legislação específica.

Agência Nacional de Vigilância Sanitária - SEPN 515, Bl.B, Ed.Ômega - Brasilia (DF) CEP 70770-502 - Tel: (61) 3448-1000

Disque Saúde: 0800611997 
ANEXO II

UNIVERSIDADE DE SÃO PAULO

Faculdade de Ciências Farmacêuticas

Secretaria de Pós-Graduação

\section{Informações para os Membros de Bancas Julgadoras de Mestrado/Doutorado}

1. O candidato fará uma apresentação oral do seu trabalho, com duração máxima de trinta minutos.

2. Os membros da banca farão a argüição oral. Cada examinador disporá, no máximo, de trinta minutos para argüir o candidato, exclusivamente sobre o tema do trabalho apresentado, e o candidato disporá de trinta minutos para sua resposta.

2.1 Com a devida anuência das partes (examinador e candidato), é facultada a argüição na forma de diálogo em até sessenta minutos por examinador.

3. A sessão de defesa será aberta ao público.

4. Terminada a argüição por todos os membros da banca, a mesma se reunirá reservadamente e expressará na ata (relatório de defesa) a aprovação ou reprovação do candidato, baseando-se no trabalho escrito e na argüição.

4.1 Caso algum membro da banca reprove o candidato, a Comissão Julgadora deverá emitir um parecer a ser escrito em campo exclusivamente indicado na ata.

4.2 Será considerado aprovado o aluno que obtiver aprovação por unanimidade ou pela maioria da banca.

5. Dúvidas poderão ser esclarecidas junto à Secretaria de PósGraduação: pgfarma@usp.br, (11) 30913621.

São Paulo, 18 de março de 2005.

Profa. Dra. Bernadette D. G. M. Franco Presidente da CPG/FCF/USP 
ANEXO III - Aval do Comitê de Ética em Experimentação Animal

UNIVERSIDADE DE SÃO PAULO

Faculdade de Ciências Farmacêuticas Comissão de Ética em Experimentação Animal - CEEA

Ofício CEEA $n^{\circ} 68 / 2006$

São Paulo, 09 de outubro de 2006.

IImo(a). Sr(a)

Bruna Kempfer Bassoli

Orientador: Prof. Fernando Salvador Moreno

FBA

Prezado(a) Senhor(a),

A Comissão de Ética em Experimentação Animal - CEEA da FCF/USP, em reunião realizada em 09 de outubro passado, APROVOU o projeto intitulado "Avaliação das eventuais atividades quimiopreventivas do ácido fólico quando administrado durante etapas pré-neoplásticas iniciais da hepatocarcinogênese em ratos" (Protocolo CEEA $n^{\circ}$ 122), apresentado por Vossa Senhoria, lembrando, apenas, que existe uma recomendação internacional sobre a não utilização do éter para anestesia.

Atenciosamente,

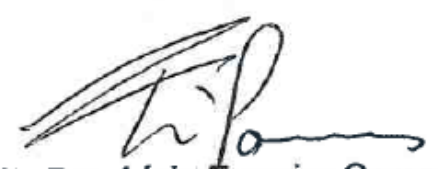

Profa. Dra. Ligia Ferreira Gomes Presidentel da CEEA 


\title{
ANEXO IV-Currículo Lattes
}

\section{Bruna Kempfer Bassoli}

Bolsista de Doutorado do CNPq

\begin{abstract}
BRUNA KEMPFER BASSOLI CONCLUIU A GRADUACAO EM BIOMEDICINA PELA UNIVERSIDADE ESTADUAL DE LONDRINA EM 2004. CONCLUIU O MESTRADO EM CIENCIA DE ALIMENTOS PELA UNIVERSIDADE ESTADUAL DE LONDRINA EM 2006. ATUALMENTE É DOUTORANDA EM CIENCIA DE ALIMENTOS-NUTRIÇÃO EXPERIMENTAL NA FACULDADE DE CIÊNCIAS FARMACÊUTICAS DA UNIVERSIDADE DE SÃO PAULO. PUBLICOU 6 ARTIGOS EM PERIODICOS ESPECIALIZADOS E 39 TRABALHOS EM ANAIS DE EVENTOS. PARTICIPOU DE 32 EVENTOS NO BRASIL E 2 INTERNACIONAIS. RECEBEU 4 PREMIOS E/OU HOMENAGENS. ENTRE 2001 E 2009 PARTICIPOU DE 3 PROJETOS DE PESQUISA. ATUA NAS ÁREAS DE NUTRIÇÃO EXPERIMENTAL, ALIMENTOS FUNCIONAIS E BIOESTATÍSTICA. EM SEU CURRICULO LATTES OS TERMOS MAIS FREQUENTES NA CONTEXTUALIZACAO DA PRODUCAO CIENTIFICA SAO: NUTRIGENÔMICA, QUIMIOPREVENÇÃO, HEPATOCARCINOGÊNESE, ÁCIDO FÓLICO, ALIMENTOS FUNCIONAIS, PERFUSAO DE FIGADO, PRODUÇÃO HEPÁTICA DE GLICOSE, ÍNDICE GLICÊMICO, GLICEMIA, COLESTEROL TOTAL, TRIACILGLICERÓIS, ÁCIDO CLOROGÊNICO, CAFÉ SOLÚVEL.
\end{abstract} (Texto informado pelo autor)

Última atualização do currículo em 26/11/2009

Endereço para acessar este CV:

http://lattes.cnpq.br/1443141064769330

\section{Dados Pessoais}

$\begin{array}{ll}\begin{array}{l}\text { Nome } \\ \text { Filiação }\end{array} & \text { Bruna Kempfer Bassoli } \\ \text { Nascimento } & \text { Denisley Gentil Bassoli e Marlene Kempfer Bassoli } \\ \text { Carteira de } & \text { 02/10/1982 - Cornélio Procópio/PR - Brasil } \\ \text { Identidade } & 60968667 \text { SSPR - PR - 18/10/1990 } \\ \text { CPF } & 03494343950 \\ & \text { Av. Nossa Senhora da Assunção, 647 apto 55 B } \\ \text { Endereço } & \text { Vila Butantã - Sao Paulo } \\ \text { residencial } & \text { 05359001, SP - Brasil } \\ & \text { Telefone: 11 86260215 } \\ & \text { Universidade de São Paulo, Faculdade de Ciências Farmacêuticas } \\ & \text { Av. Prof. Lineu Prestes, 580 } \\ \text { Endereço } & \text { Butantã - Sao Paulo } \\ \text { profissional } & \text { 05508-900, SP - Brasil } \\ & \text { Telefone: 11 30913630 } \\ \text { Endereço eletrônico } & \text { e-mail para contato : bruna_kb@usp.br } \\ \text { e-mail alternativo : bruestado@bol.com.br }\end{array}$




\title{
Formação Acadêmica/Titulação
}

2006

$2004-2006$

$1999-2004$
Doutorado em Ciência dos Alimentos-Nutrição Experimental.

Universidade de São Paulo, USP, Sao Paulo, Brasil

Título: Avaliação da eventual atividade quimiopreventiva do ácido fólico quando administrado durante a etapa de promoção inicial da hepatocarcinogênese em ratos.

Orientador: Porf. Titular Fernando Salvador Moreno

Bolsista do(a): Conselho Nacional de Desenvolvimento Científico e Tecnológico

Mestrado em Ciência de Alimentos.

Universidade Estadual de Londrina, UEL, Brasil

Título: Bioensaios para avaliação de propriedades fisiologicamente funcionais do ácido clorogênico e do extrato de café solúvel com altos teores de ácidos clorogênicos., Ano de obtenção: 2007

Orientador: Dr Rui Sérgio dos Santos Ferreira da Silva

Bolsista do(a): Conselho Nacional de Desenvolvimento Científico e Tecnológico

Graduação em Biomedicina.

Universidade Estadual de Londrina, UEL, Londrina, Brasil

Título: Efeito do ácido clorogênico sobre a ação do glucagon na produção hepática de glicose, glicogenólise e glicólise: estudos em perfusão de fígado Orientador: Dr ${ }^{\mathrm{a}}$ Helenir Medri de Souza

Bolsista do(a): Universidade Estadual de Londrina -IC /UEL-Compania Iguaçú de Café Solúvel

\section{Formação complementar}

\author{
2003 - 2005 Pós Graduação em Língua Inglesa. \\ Instituto Cultural Brasil Estados Unidos, ICBEU, Brasil \\ Estágio em Fisiologia-Bioquímica. \\ 2003 - $2004 \quad$ Universidade Estadual de Londrina, UEL, Brasil \\ Bolsista do(a): Universidade Estadual de Londrina -IC /UEL-Compania Iguaçú \\ de Café Solúvel \\ 2002 - $2003 \quad$ Universidade Estadual de Londrina, UEL, Brasil \\ Bolsista do(a): Universidade Estadual de Londrina-IC/UEL \\ 2003 - $2003 \quad$ Proeficiência em Inglês. \\ Instituto Cultural Brasil Estados Unidos, ICBEU, Brasil \\ 2001 - $2002 \quad$ Estágio em Histologia. \\ Universidade Estadual de Londrina, UEL, Brasil \\ 2002 - $2002 \quad$ Estágio em Fisiologia. \\ Universidade Estadual de Londrina, UEL, Brasil \\ 2000 - $2000 \quad$ Proeficiência em Língua Inglesa. \\ Richard H Fisk Foundation, FISK*, Brasil \\ 1997 - 1998 Graduação em Língua Inglesa. \\ Richard H Fisk Foundation, FISK*, Brasil \\ $1994-1997$ \\ Curso de curta duração em Matemática Estágio I. \\ Kumon Instituto de Educação, KUMON, Brasil \\ $1994-1996$ \\ Conclusão do Curso de Língua Espanhola. \\ Centro de Língua Estrangeira Moderna, CELEM, Brasil \\ $1994-1996$ \\ Inglês Intermediário.
}


Skill Aliança Inglesa, SKILL*, Brasil

\begin{tabular}{|c|c|}
\hline 1994 - 1995 & $\begin{array}{l}\text { Curso de curta duração em MS DOS. } \\
\text { Solução Informática, SOLUÇÃO INFOMÁTI, Brasil }\end{array}$ \\
\hline 95 - 1995 & $\begin{array}{l}\text { Curso de curta duração em Wordstar. } \\
\text { Solução Infomática, SOLUÇÃOINFOMÁTIC, Brasil }\end{array}$ \\
\hline 995 & $\begin{array}{l}\text { Curso de curta duração em Windows. } \\
\text { Solução Infomática, SOLUÇÃOINFOMÁTIC, Brasil }\end{array}$ \\
\hline $94-199$ & $\begin{array}{l}\text { Curso de curta duração em Introdução à Informática. } \\
\text { Solução Infomática, SOLUÇÃOINFOMÁTIC, Brasil }\end{array}$ \\
\hline
\end{tabular}

\section{Atuação profissional}

\section{Universidade de São Paulo - USP}

\section{Vínculo institucional}

2006 - Atual

\section{Atividades}

10/2009 - 10/2009

10/2009 - 10/2009

10/2008 - 10/2008

08/2008 - 12/2008

02/2008 - 06/2008
10/2008 - 10/2008

Vínculo: Aluna de Doutorado, Enquadramento funcional: Doutoranda em Nutrição Experimental, Regime: Dedicação Exclusiva

Aperfeiçoamento

Especificação:

Ministrou o curso: Resultados experimentais sob a ótica da Bioestatística: as diferenças observadas são significativas? (8 horas)

Aperfeiçoamento

Especificação:

Ministrou o curso: Análise Multivariada: técnicas estatísticas avançadas auxiliando na compreensão global dos resultados de Biologia Molecular e de Ciência dos Alimentos. (8 horas)

Aperfeiçoamento

Especificação:

Ministrou o curso: Complexidade dos resultados das Ciências Biológicas e dos Alimentos sob uma nova abordagem: Análise Multivariada (8 horas)

Aperfeiçoamento

Especificação:

Ministrou o curso: Bioestatística na validação de diferenças experimentais: testes de hipóteses e correlações (8 horas)

Estágio, Faculdade de Saúde Pública, Departamento de Epidemiologia

Estágio:

Estágio Supervisionado em Docência (75 horas) do Programa de Aperfeiçoamento de Ensino junto à Disciplina HEP-0103 Bioestatística em Nutrição

Estágio, Faculdade de Ciências Farmacêuticas, Departamento de Alimentos e Nutrição Experimental

Estágio:

Estágio Supervisionado em Docência (45 horas) do Programa de Aperfeiçoamento de Ensino junto à Disciplina FBA-0407 Fundamentos da Análise Sensorial de Alimentos

10/2007 - 10/2007 Aperfeiçoamento

Especificação:

Ministrou o curso: Bioestatística Aplicada: Noções de Planejamento 
Experimental e Interpretação de Resultados (16 horas)

05/2007 - 05/2007 Outra atividade técnico-científica, Faculdade de Ciências Farmacêuticas

Especificação:

Curso: "Desenho experimental e determinação do tamanho da amostra em experimentos com animais."

2006 - Atual Projetos de pesquisa, Faculdade de Ciências Farmacêuticas

Participação em projetos:

Avaliação da eventual atividade quimiopreventiva do ácido fólico quando administrado durante a etapa de promoção inicial da hepatocarcinogênese em ratos.

2006 - Atual Pesquisa e Desenvolvimento, Faculdade de Ciências Farmacêuticas

Linhas de Pesquisa:

Avaliação das eventuais atividades quimiopreventivas do ácido fólico quando administrado durante etapas pré-neoplásicas iniciais da hepatocarcinogênese em ratos.

\section{Universidade Estadual de Londrina - UEL}

\section{Vínculo institucional}

$2004-2006$

$1999-2004$

Atividades

$2004-2006$

$2004-2006$

10/2004 - 10/2004

$2003-2006$

$12 / 2003-12 / 2003$
Vínculo: Aluna de Mestrado, Enquadramento funcional: Mestranda em Ciência de Alimentos, Regime: Dedicação Exclusiva

Vínculo: Aluna de Graduação , Enquadramento funcional: Aluna do Curso de Biomedicina, Regime: Parcial

Estágio, Departamento de Tecnologia de Alimentos e Medicamentos

Estágio:

Estágio - desenvolvimento da dissertação - Extrato de café solúvel com altos teores de ácido clorogênico como ingrediente fisiologicamente funcional: efeitos sobre a produção hepática de glicose, glicogenólise e glicólise em perfusão de fígado

Projetos de pesquisa, Departamento de Tecnologia de Alimentos e Medicamentos Participação em projetos:

Bioensaios para avaliação de propriedades fisiologicamente funcionais do ácido clorogênico e do extrato de café solúvel com altos teores de ácidos clorogênicos.

Outra atividade técnico-científica, Universidade Estadual de Londrina-Curso de Biomedicina

Especificação:

Palestra sobre o tema: Biomedicina-uma visão de recém-formados

Projetos de pesquisa, Universidade Estadual de Londrina-Departamento de Ciências Fisiológicas

Participação em projetos:

Efeito dos ácidos clorogênicos extraídos do café solúvel Iguaçú sobre a glicemia e outros parâmetros metabólicos em modelo de rato diabético tipo 2.

Outra atividade técnico-científica, Universidade Estadual de Londrina-Curso de Biomedicina

Especificação:

Apresentação oral sobre o tema: Ácido clorogênico e o metabolismo hepático da glicose

07/2003 - 07/2003 Outra atividade técnico-científica, Universidade Estadual de Londrina-Curso de 
Biomedicina

Especificação:

Palestra sobre o tema: Alimentos funcionais: os carotenóides

02/2003 - 01/2004 Estágio, Departamento de Ciências Fisiológicas

Estágio:

Estágio - desenvolvimento do trabalho de conclusão de Curso - Efeito do ácido clorogênico sobre a ação do glucagon na produção hepática de glicose, glicogenólise e glicólise: estudos em perfusão de fígado

$2002-2006$

Pesquisa e Desenvolvimento, Universidade Estadual de Londrina-Departamento de Ciências Fisiológicas

Linhas de Pesquisa:

Regulação do metabolismo hepático de carboidratos. , Efeito do ácido clorogênico no metabolismo hepático da glicose.

08/2002 - 01/2003 Estágio, Departamento de Ciências Fisiológicas

Estágio:

Bolsista de iniciação científica desenvolvendo atividades relativas à pesquisa intitulada "Efeito da leptina sobre o metabolismo hepático da glicose: estudos em perfusão de fígado e em hepatócitos isolados"

03/2002 - 07/2002 Estágio, Departamento de Ciências Fisiológicas

Estágio:

Colaboradora no projeto de pesquisa: "Efeito da leptina sobre o metabolismo hepático da glicose: estudos em perfusão de fígado e em hepatócitos isolados"

03/2001 - 03/2002 Estágio, Departamento de Histologia

Estágio:

Estágio voluntário: Noções de histologia e treinamento para desenvolvimento de protocolos experimentais envolvendo, entre outros, controle de alimentação seletiva, pesagem e coleta de sangue para análises bioquímicas

Projetos de pesquisa, Universidade Estadual de Londrina-Departamento de Ciências Fisiológicas

Participação em projetos:

Efeito da leptina sobre o metabolismo hepático da glicose: estudos em perfusão de fígado e em hepatócitos isolados.

\section{Linhas de Pesquisa}

1.

2.

3.
Regulação do metabolismo hepático de carboidratos.

Efeito do ácido clorogênico no metabolismo hepático da glicose.

Avaliação das eventuais atividades quimiopreventivas do ácido fólico quando administrado durante etapas pré-neoplásicas iniciais da hepatocarcinogênese em ratos.

Grande área: Ciências da Saúde / Área: Nutrição / Subárea: Nutrição Experimental.

Grande área: Ciências Biológicas / Área: Genética / Subárea: Biologia Molecular.

Setores de atividade: Nutrição e alimentação.

Palavras-chave: ácido fólico; hepatocarcinogênese; quimioprevenção; biologia molecular; nutrigenômica; metilação do DNA. 


\section{Projetos de Pesquisa}

2006 - Atual

$2004-2006$

2003 - Atual
Avaliação da eventual atividade quimiopreventiva do ácido fólico quando administrado durante a etapa de promoção inicial da hepatocarcinogênese em ratos.

Descrição: O processo de metilação do DNA consiste em um importante evento epigenético relacionado com a carcinogênese. Especialmente na hepatocarcinogênese, descreve-se hipometilação do DNA e aumento da expressão de oncogenes já durante suas etapas iniciais pré-neoplásicas. 0 ácido fólico tem importante papel no metabolismo dos grupamentos metila, que, em última instância, irá formar S-adenosil-L-metionina (SAM), doadora universal de radicais metila, necessários a diversas moléculas dentre elas o DNA. Alguns estudos demonstram que a suplementação com ácido fólico resulta em efeito quimiopreventivo contra o câncer de cólon induzido em ratos. Entretanto, tal efeito parece depender da dose e do estágio do desenvolvimento neoplásico em que se inicia a suplementação. Nesse sentido, o modelo de hepatocarcinogênese do Hepatócito Resistente (RH) está bem caracterizado e é suficiente para induzir elevada incidência de lesões pré-neoplásicas (LPN) e neoplásicas de forma sincronizada, possibilitando, desta forma, estudos mais detalhados, inclusive da quimioprevenção do câncer. Não existem relatos na literatura a respeito de ação quimiopreventiva dessa vitamina em modelos de hepatocarcinogênese; entretanto, a administração de SAM a ratos submetidos ao modelo do $\mathrm{RH}$ resultou em atividade quimiopreventiva. Assim, o presente projeto objetiva avaliar a eventual atividade quimiopreventiva, a proliferação celular e a apoptose após administração de ácido fólico, precursor da SAM, durante a etapa de promoção inicial da hepatocarcinogênese em ratos. Além disso, será também avaliada a taxa de metilação global bem como o padrão de metilação e a expressão do oncogene c-myc especificamente de lesões pré-neoplásicas e do tecido hepático normal a seu redor obtidos por procedimento de microdissecção tecidual.

Situação: Em andamento; Natureza: Pesquisa.

Alunos envolvidos: Graduação ( 2) / Doutorado ( 2) .

Integrantes: Bruna Kempfer Bassoli - Coordenador.

Financiador(es): Conselho Nacional de Desenvolvimento Científico e Tecnológico Bolsa..

Bioensaios para avaliação de propriedades fisiologicamente funcionais do ácido clorogênico e do extrato de café solúvel com altos teores de ácidos clorogênicos.

Situação: Concluído; Natureza: Pesquisa.

Alunos envolvidos: Graduação ( 1) .

Integrantes: Bruna Kempfer Bassoli - Coordenador.

Financiador(es): Conselho Nacional de Desenvolvimento Científico e Tecnológico Bolsa..

Efeito dos ácidos clorogênicos extraídos do café solúvel Iguaçú sobre a glicemia e outros parâmetros metabólicos em modelo de rato diabético tipo 2.

Descrição: O ácido clorogênico é um produto natural e o café é a principal fonte de ácido clorogênico da dieta humana. Estudos recentes têm demonstrado que derivados sintéticos do ácido clorogênico são efetivos na inibição da liberação hepática de glicose e redução da glicemia em animais não diabéticos. $O$ presente projeto propõe investigar, entre outros efeitos (glicogenólise, neoglicogênese, perfil lipídico plasmático, conteúdo de glicogênio hepático), se os ácidos clorogênicos extraídos do café solúvel Iguaçú reduzem a hiperglicemia de animais portadores de diabetes tipo 2. Nos experimentos serão utilizados ratos machos adultos, da linhagem Wistar, pesando entre 200 e 250 g, diabéticos ou não, alimentados ou submetidos a 24 horas de privação alimentar, dependendo do parâmetro a ser investigado. Os ratos normais e diabéticos receberão por via oral ou intraperitoneal os ácidos clorogênicos. Após 30 minutos ou mais, amostras de sangue serão coletadas do animal para dosagem das concentrações plasmáticas de glicose, ácidos graxos livres (AGL), colesterol total e triglicérides. Os efeitos dos ácidos clorogênicos sobre a concentração de glicogênio hepático, glicogenólise e neoglicogênese hepática serão investigados em perfusão de fígado in situ de ratos diabéticos tipo 2 . É possível que o ácido clorogênico, extraído do café solúvel Iguaçú, possa reduzir da liberação hepática de glicose e glicemia em animais portadores de diabetes tipo 2. Assim, o ácido clorogênico poderia apresentar potencial terapêutico como agente para o tratamento da hiperglicemia associada ao diabetes tipo 2.

Situação: Em andamento; Natureza: Pesquisa.

Alunos envolvidos: Graduação ( 1) / Mestrado acadêmico ( 1) .

Integrantes: Helenir Medri de Souza - Coordenador / Gláucia Regina Borba Murad Integrante / Cássia Thais B V Zaia - Integrante / Priscila Cassolla - Integrante / Bruna Kempfer Bassoli - Integrante. 
$2001-2003$

Financiador(es): Companhia Iguaçú de Café Solúvel - Auxílio financeiro / Universidade Estadual de Londrina -IC /UEL-Compania Iguaçú de Café Solúvel - Bolsa / Conselho Nacional de Desenvolvimento Científico e Tecnológico - Auxílio financeiro / Conselho Nacional de Desenvolvimento Científico e Tecnológico - Bolsa.

Número de produções $C, T$ \& A: 6.

Efeito da leptina sobre o metabolismo hepático da glicose: estudos em perfusão de fígado e em hepatócitos isolados.

\footnotetext{
Descrição: A leptina é uma proteína secretada pelo tecido adiposo que atua no sistema nervoso central inibindo a ingestão de alimentos e estimulando a taxa metabólica. Além destes efeitos centrais, tem sido relatado que a leptina apresenta ação direta em vários tecidos periféricos, incluindo o fígado. No fígado a leptina aumenta a síntese de glicogênio, a atividade da glicogêniosintase e o efeito inibitório da insulina na glicogenólise, enquanto reduz a liberação de glicose, estimulada pela adrenalina e pelo glucagon, e a neoglicogênese de vários precursores. Embora estas evidências indiquem que a leptina tem efeito no metabolismo hepático da glicose, poucos trabalhos têm sido publicados nesta área e muitas questões permanecem a ser investigadas. Diante disto, o presente projeto se propõe a investigar em perfusão de fígado e em hepatócitos isolados de ratos, o efeito da leptina sobre a glicogenólise e neoglicogênese estimulada por AMPc, dibutiril-AMPc, isoproterenol e fenilefrina (agentes estimuladores da produção de glicose).

Situação: Concluído; Natureza: Pesquisa.

Alunos envolvidos: Graduação ( 8) / Especialização ( 0) / Mestrado acadêmico ( 0) / Mestrado profissionalizante ( 0) / Doutorado ( 1) .

Integrantes: Helenir Medri de Souza - Coordenador / Érica Guilhen Mario - Integrante / Gláucia Regina Borba Murad - Integrante / Horácio Mori - Integrante / Roberto Barbosa Bazotte - Integrante / Bruna Kempfer Bassoli - Integrante.

Financiador(es): Universidade Estadual de Londrina - Bolsa / Conselho Nacional de Desenvolvimento Científico e Tecnológico - Auxílio financeiro.

Número de produções $C, T$ \& A: 7.
}

\title{
Áreas de atuação
}

\author{
1. Nutrição Experimental \\ 2. Alimentos Funcionais \\ 3. Bioestatística \\ 4. Bioquímica da Nutrição \\ 5. Ciência de Alimentos \\ 6. Fisiologia
}

\section{Idiomas}

Inglês

Espanhol

\section{Prêmios e títulos}

Compreende Bem, Fala Bem, Lê Bem, Escreve Bem.

Compreende Bem, Fala Razoavelmente, Lê Bem, Escreve Razoavelmente.

Co-autora do melhor trabalho de pós-doutorado, Faculdade de Cïências Farmacêuticas-USP 


\section{Produção em C, T\& A}

\section{Produção bibliográfica}

\section{Artigos completos publicados em periódicos}

MARIO, E. G., LEONARDO, E. S., BASSOLI, B. K., CASSOLLA, P., BORBA-MURAD, G. 1. R., BAZOTTE, R. B., SOUZA, H. M.

1. Investigation of the acute effect of leptin on the inhibition of glycogen catabolism by insulin in rat liver perfused in situ. Pharmacological Reports. , v.61, p.319 - 324, 2009.

doi> LEONARDO, E. S., BASSOLI, B. K., CASSOLLA, P., BORBA-MURAD, G. R., BAZOTTE, R. B., SOUZA, H. M.

2. Leptin inhibits glycogen catabolism but does not modify acutely the suppressive effect of insulin on glucose production and glycogenolysis stimulated by 8-Br-cAMP in rat liver perfused in situ. Pharmacological Research. , v.59, p.176 - 182, 2009.

doi> BASSOLI, B. K., CASSOLLA, P., BORBA-MURAD, G. R., CONSTANTIN, J., SALGUEIRO-PAGADIGORRIA, C. L., BAZOTTE, R. B., SILVA, R. S. S. F., SOUZA, H. M.

3. Chlorogenic acid reduces the plasma glucose peak in the oral glucose tolerance test: effects on hepatic glucose release and glycaemia. Cell Biochemistry and Function. , v.26, n. 3, p. 320-328, 2008.

BORBA-MURAD, G. R., VARDANEGA-PEICHER, M., GALENDE, S. B., CURI, R., SOUZA, 4. H. M., MARIO, E. G., BASSOLI, B. K., BAZOTTE, R. B.

4. Central role of cAMP in the inhibition of glycogen breakdown and gluconeogenesis promoted by leptin and insulin in perfused rat liver. Polish Journal of Pharmacology. , v.56, p.223 - 231, 2004.

BORBA-MURAD, G. R., MARIO, E. G., BASSOLI, B. K., BAZOTTE, R. B., SOUZA, H. M.

5. Comparative acute effects of leptin and insulin on gluconeogenesis and ketogenesis in perfused rat liver. Cell Biochemistry and Function. , v.22, p.1 - 9, 2004.

BASSOLI, B. K., MARIO, E. G., MORI, H., BORBA-MURAD, G. R., BAZOTTE, R. B.,

6. SOUZA, H. M.

Efeito insulin-like da leptina na neoglicogênese hepática. Biosaúde (Londrina). , v.4, p.5 - 16, 2003.

\section{Trabalhos publicados em anais de eventos (completo)}

BASSOLI, B. K., CASSOLLA, P., BORBA-MURAD, G. R., SILVA, R. S. S. F., BAZOTTE, R. B., SOUZA, H. M.

1. Bioassays to evaluate the physiological functional properties of chlorogenic acid and of an instant

coffee extract with high levels of chlorogenic acids In: 21st International Conference on Coffee Science, 2006, Montpellier.

21st International Conference on Coffee Science. , 2006. p.65 - 72

BASSOLI, B. K., CASSOLLA, P., BORBA-MURAD, G. R., SILVA, R. S. S. F., BAZOTTE, R. B., SOUZA, H. M.

2. Study of chlorogenic acid functional properties: effects on hepatic glucose output, blood glucose levels and plasmatic lipids In: 21st International Conference on Coffee Science, 2006, Montpellier.

21st International Conference on Coffee Science. , 2006. p.105 - 110

\section{Trabalhos publicados em anais de eventos (resumo)}

CHAGAS, C. E. A., BASSOLI, B. K., ONG, T. P., MORENO, F. S.

A atividade quimiopreventiva do ácido fólico envolve redução de danos no DNA hepático e da

1. expressão do oncogene c-myc especificamente em lesões pré-neoplásicas GST-P positivas persistentes microdissecadas. In: $10^{\circ}$ Congresso Nacional da Sociedade Brasileira de Alimentação e Nutrição, 2009, São Paulo.

Nutrire. , 2009. v.34. p.47- 47 
HEIDOR, R., VIEIRA, A., CHAGAS, C. E. A., BASSOLI, B. K., CONTI, A., PURGATTO, E., ONG, T. P., MORENO, F. S.

2. Atividade quimiopreventiva da tributirina não envolve modulação do padrão de metilação global do DNA em ratos submetidos a modelo de carcinogênese de cólon. In: $10^{\circ}$ Congresso Nacional da Sociedade Brasileira de Alimentação e Nutrição, 2009, São Paulo.

Nutrire. , 2009. v.34. p.34 - 34

OKAMOTO, L., CHAGAS, C. E. A., BASSOLI, B. K., CONTI, A., POLA, A. R., ANDRADE, F. O., BARBISAN, L. F., JORDAO JR, A. A., MORENO, F. S., ONG, T. P.

3. Ausência de atividade quimiopreventiva por parte da vitamina A quando administrada a ratas na etapa de pós-iniciação da carcinogênese mamária. In: $10^{\circ}$ Congresso Nacional da Sociedade Brasileira de Alimentação e Nutrição, 2009, São Paulo.

Nutrire. , 2009. v.34. p.48 - 48

VIEIRA, A., HEIDOR, R., BASSOLI, B. K., ONG, T. P., BARBISAN, L. F., MORENO, F. S. Effects of different doses of geraniol in mucin-depleted colonic foci induced by 1,2-

4. dimethylhydrazine in rats. In: XIV Semana Farmacêutica de Ciência e Tecnologia, 2009, São Paulo.

Brazilian Journal of Pharmaceutical Sciences. , 2009. v.45. p.50 - 50

CHAGAS, C. E. A., BASSOLI, B. K., HEIDOR, R., ONG, T. P., MORENO, F. S.

5. Folic acid (FA) chemopreventive activity during the initial phases of hepatocarcinogenesis in rats. In: XV Congreso Latinoamericano de Nutrición, 2009, Santiago.

CD XV Congreso Latinoamericano de Nutrición. , 2009. p.413 - 413

BASSOLI, B. K., CHAGAS, C. E. A., CONTI, A., ONG, T. P., MORENO, F. S. Folic acid supplementation, dna methylation and c-myc proto-oncogene expression during

6. hepatocarcinogenesis early promotion in rats. In: XV Congreso Latinoamericano de Nutrición, 2009, Santiago.

CD XV Congreso Latinoamericano de Nutrición. , 2009. p.407 - 407

BASSOLI, B. K., CHAGAS, C. E. A., DAGLI, M. L. Z., ORTEGA, J. F., ONG, T. P., SCOLASTICI, C., MORENO, F. S.

7. Suplementação com ácido fólico, danos no DNA e apoptose na etapa de promoção inicial da hepatocarcinogênese em ratos. In: $10^{\circ}$ Congresso Nacional da Sociedade Brasileira de Alimentação e Nutrição, 2009, São Paulo.

Nutrire. , 2009. v.34. p.43 - 43

SCOLASTICI, C., CARDOZO, M. T., HORST, M. A., BASSOLI, B. K., ONG, T. P., MORENO, F. S.

8. TGF- $\alpha$ expression reduction in persistent preneoplasic lesion could be related to beta-ionone chemopreventive activity during promotion phase of hepatocarcionogenesis in rats. In: XIV Semana Farmacêutica de Ciência e Tecnologia, 2009, São Paulo.

Brazilian Journal of Pharmaceutical Sciences. , 2009. v.45. p.63 - 63

HORST, M. A., SCOLASTICI, C., BASSOLI, B. K., CONTI, A., CARDOZO, M. T., HEIDOR, R., ONG, T. P., MORENO, F. S.

9. The chemopreventive effects of tributyrin during rat hepatocarcinogenesis promotion involve apoptosis induction followed by cell proliferation inhibition. In: XIV Semana Farmacêutica de Ciência e Tecnologia, 2009, São Paulo.

Brazilian Journal of Pharmaceutical Sciences. , 2009. v.45. p.27 - 27

OKAMOTO, L., CHAGAS, C. E. A., BASSOLI, B. K., CONTI, A., POLA, A. R., ANDRADE, F. O., DAGLI, M. L. Z., MORENO, F. S., ONG, T. P.

Efeitos da administração de vitamina $\mathrm{A}$ a ratas submetidas a modelo de carcinogênese mamária

10. induzida quimicamente In: XIII Semana Farmacêutica de Ciência e Tecnologia, 2008, São Paulo.

Revista Brasileira de Ciências Farmacêuticas. , 2008. v.0. p.0 - 0 
CHAGAS, C. E. A., SOUZA, C. A. S., BASSOLI, B. K., ONG, T. P., MORENO, F. S. A atividade quimiopreventiva do ácido fólico quando administrado continuamente durante as 11. etapas de iniciação e promoção inicial da hepatocarcinogênese em ratos envolve inibição da proliferação celular especificamente em lesões pré-neoplásicas persistentes In: XII Semana Farmacêutica da USP, 2007, São Paulo.

Revista Brasileira de Ciências Farmacêuticas. , 2007. v.43. p.32 - 32

BASSOLI, B. K., CHAGAS, C. E. A., DALLACQUA, M. C., ONG, T. P., MORENO, F. S.

12. Ácido fólico inibe a proliferação celular na etapa de promoção inicial da hepatocarcinogênese em ratos In: XII Semana Farmacêutica da USP, 2007, São Paulo.

Revista Brasileira de Ciências Farmacêuticas. , 2007. v.43. p.33 - 33

CARDOZO, M. T., BASSOLI, B. K., ORMUNDO, W. N., SCOLASTICI, C., ONG, T. P., MORENO, F. S.

Alterações em vias de p53 e rho A parecem estar relacionados às atividades quimiopreventivas dos

13. isoprenóides b-ionona e geraniol, quando administrados a ratos durante a fase de promoção inicial da hepatocarcinogênese In: $9^{\circ}$ Congresso Nacional da Sociedade Brasileira de Alimentação e Nutrição, 2007, São Paulo.

Nutrire. São Paulo: , 2007. v.32. p.26 - 26

ONG, T. P., CHAGAS, C. E. A., BASSOLI, B. K., CONTI, A., CAVALHER, F. P., CAMARGO, A. M. A., JORDAO JR, A. A., VANNUCCHI, H., DAGLI, M. L. Z., MORENO, F. S.

14. Alterações no metabolismo da vitamina A em hepatocarcinomas de ratos não envolvem silenciamento epigenético do gene para a proteína ligadora de retinol celular tipo I (CRBP-I) In: $9^{\circ}$ Congresso Nacional da Sociedade Brasileira de Alimentação e Nutrição, 2007, São Paulo.

Nutrire. São Paulo: , 2007. v.32. p.89 - 89

CHAGAS, C. E. A., SOUZA, C. A. S., BASSOLI, B. K., ONG, T. P., MORENO, F. S.

Atividade quimiopreventiva do ácido fólico quando administrado durante as fases de iniciação e

15. seleção/promoção da hepatocarcinogênese em ratos In: $9^{\circ}$ Congresso Nacional da Sociedade

Brasileira de Alimentação e Nutrição, 2007, São Paulo.

Nutrire. São Paulo: , 2007. v.32. p.27 -

BASSOLI, B. K., CHAGAS, C. E. A., ORTEGA, J. F., ONG, T. P., MORENO, F. S.

Efeitos do ácido fólico na etapa de promoção inicial da hepatocarcinogênese em ratos dependem

16. de sua dosagem In: $9^{\circ}$ Congresso Nacional da Sociedade Brasileira de Alimentação e Nutrição, 2007, São Paulo.

Nutrire. São Paulo: , 2007. v.32. p.260 - 260

BASSOLI, B. K., CASSOLLA, P., BORBA-MURAD, G. R., SILVA, R. S. S. F., BAZOTTE, R. B., SOUZA, H. M.

17. Propriedades funcionais dos ácidos clorogênicos do café In: $14^{\circ}$ Congresso Latino Americano de Nutrição, 2006, Florianópolis.

CD-ROM 14 ${ }^{\circ}$ Congresso Latino Americano de Nutrição. , 2006.

LEONARDO, E. S., CASSOLLA, P., BASSOLI, B. K., SILVA, C. E. A., BAZOTTE, R. B., BORBA-MURAD, G. R., SOUZA, H. M.

18. Altas concentações de leptina não modificam a sensitividade à insulina em perfusão de fígado de rato In: XX Reunião Anual da Federação de Sociedades de Biologia Experimental, 2005, Águas de Lindóia-SP.

CD-ROM FeSBE 2005. , 2005. p.19 - 20

BASSOLI, B. K., CASSOLLA, P., LEONARDO, E. S., SILVA, C. E. A., BAZOTTE, R. B., BORBA-MURAD, G. R., SOUZA, H. M.

Efeito do ácido clorogênico sobre a liberação hepática de glicose: neoglicogênese de vários

19. precursores In: XX Reunião Anual da Federação de Sociedades de Biologia Experimental, 2005, Águas de Lindóia-SP.

CD-ROM FeSBE 2005. , 2005. p.19 - 19 
SILVA, C. E. A., BORBA-MURAD, G. R., CASSOLLA, P., BASSOLI, B. K., BAZOTTE, R. B., SOUZA, H. M.

20. Efeito do ácido clorogênico sobre a liberação hepática de glicose: neoglicogênese de vários precursores In: XIV Encontro Anual de Iniciação Científica, 2005, Guarapuava-PR.

CD-ROM EAIC 2005. , 2005.

BASSOLI, B. K., CASSOLLA, P., SILVA, C. E. A., BORBA-MURAD, G. R., BAZOTTE, R. B., SILVA, R. S. S. F., SOUZA, H. M.

Estudos comparativos do extrato de café solúvel com alto teor de ácidos clorogênicos com o ácido

21. clorogênico grau analítico nos efeitos sobre a glicemia e colesterol total, neoglicogênese, glicogenólise e glicólise em perfusão de fígado In: $6^{\circ}$ Simpósio Latino Americano de Ciência de Alimentos, 2005, Campinas.

CD-ROM 6 ${ }^{\circ}$ Simpósio Latino Americano de Ciência de Alimentos. , 2005.

LEONARDO, E. S., SILVA, C. E. A., CASSOLLA, P., BASSOLI, B. K., BAZOTTE, R. B., BORBA-MURAD, G. R., SOUZA, H. M.

22. Central role of cAMP in the inhibition of glycogenolysis and gluconeogenesis promoted by leptin and insulin in perfused rat liver In: VI Congresso Londrinense de Biologia Aplicada à Saúde e I Simpósio Paranaense de Patologia Experimental, 2004, Londrina-PR.

Biosaúde. Londrina: UEL, 2004. v.6. p.172 - 172

MARIO, E. G., BASSOLI, B. K., LEONARDO, E. S., SILVA, C. E. A., BORBA-MURAD, G. R., BAZOTTE, R. B., SOUZA, H. M.

23. Comparative acute effects of leptin and insulin on gluconeogenesis and ketogenesis in perfused rat liver In: XIX Reunião Anual da Federação de Sociedade de Biologia Experimental, 2004, Águas de Lindóia.

CD-ROM FeSBE 2004. , 2004.

BORBA-MURAD, G. R., MARIO, E. G., BASSOLI, B. K., GALENDE, S. B., BAZOTTE, R. B., SOUZA, H. M.

Comparative effects of leptin and insulin on gluconeogenesis and ketogenesis in perfused rat liver

24. In: XXXVI Congresso Brasileiro de Farmacologia e Terapêutica Experimental, 2004, Águas de Lindóia.

CD-Rom do XXXVI Congresso Brasileiro de Farmacologia e Terapêutica Experimental. , 2004. p.186 - 186

SILVA, C. E. A., CASSOLLA, P., BASSOLI, B. K., LEONARDO, E. S., BAZOTTE, R. B., BORBA-MURAD, G. R., SOUZA, H. M.

25. Comparative effects of leptin and insulin on gluconeogenesis and ketogenesis in perfused rat liver In: VI Congresso Londrinense de Biologia Aplicada à Saúde e I Simpósio Paranaense de Patologia Experimental, 2004, Londrina-PR.

Biosaúde. Londrina: UEL, 2004. v.6. p.171 - 171

ARAÚJO, C. E., LEONARDO, E. S., CASSOLLA, P., BASSOLI, B. K., NOGUEIRA, E. E., BAZOTTE, R. B., BORBA-MURAD, G. R., SOUZA, H. M.

Efeito comparativo da leptina e insulina na neoglicogênese e cetogênese em perfusão de fígado de

26. rato In: II Simpósio Integrado dos Bacharelandos em Biomedicina e II Mostra de Painéis em Biomedicina, 2004, Londrina-PR.

CR-ROM II Simpósio Integrado dos Bacharelandos em Biomedicina e II Mostra de Painéis em Biomedicina. , 2004.

LEONARDO, E. S., BASSOLI, B. K., SILVA, C. E. A., MARIO, E. G., BORBA-MURAD, G. R., ZAIA, C. T. B. V., BAZOTTE, R. B., SOUZA, H. M.

Efeito do ácido clorogênico sobre a ação do glucagon na produção hepática de glicose,

27. glicogenólise e glicólise In: XIX Reunião Anual da Federação de Sociedades de Biologia Experimental, 2004, Águas de Lindóia.

CD-ROM FeSBE 2004. , 2004. 
LEONARDO, E. S., ARAÚJO, C. E., CASSOLLA, P., BASSOLI, B. K., BAZOTTE, R. B., BORBA-MURAD, G. R., SOUZA, H. M.

Papel central do AMPc na inibição da glicogenólise e neoglicogênese promovida pela leptina e

28. insulina em perfusão de fígado de rato In: II Simpósio Integrado dos Bacharelandos em

Biomedicina e II Mostra de Painéis em Biomedicina

CD-ROM II Simpósio Integrado dos Bacharelandos em Biomedicina e II Mostra de Painéis em Biomedicina. , 2004.

MARIO, E. G., BASSOLI, B. K., SANTOS, P. N. H., MOREIRA, C. Q., VARDANEGAPEICHER, M., BORBA-MURAD, G. R., BAZOTTE, R. B., SOUZA, H. M.

A leptina, como a insulina, inibe a glicogenólise e a neoglicogênese hepática estimulada por

29. nucleotídeos cíclicos In: I Simpósio Integrado dos Bacharelandos em Biomedicina e I Mostra de Painéis em Biomedicina, 2003, Londrina-PR.

CR-ROM I Simpósio Integrado dos Bacharelandos em Biomedicina e I Mostra de Painéis em Biomedicina. , 2003.

MARIO, E. G., BASSOLI, B. K., VARDANEGA-PEICHER, M., BORBA-MURAD, G. R., BAZOTTE, R. B., SOUZA, H. M.

30. A leptina, como a insulina, inibe a glicogenólise e a neoglicogênese hepática estimulada por nucleotídeos cíclicos In: XVIII Reunião Anual da Federação de Sociedades de Biologia

Experimental, 2003, Curitiba.

CD-ROM FeSBE2003. , 2003.

MARIO, E. G., BASSOLI, B. K., VARDANEGA-PEICHER, M., BORBA-MURAD, G. R., BAZOTTE, R. B., SOUZA, H. M.

Comparative effect of leptin and insulin on the activation of glycogen catabolism and

31. gluconeogenesis promoted by cyclic nucleotides in isolated rat liver In: XXXVIII Congresso da Sociedade Brasileira de Fisiologia SBfis / XXI Congresso da Associação Latino-Americana de Ciências Fisiológicas ALACF, 2003, Ribeirão Preto.

Livro de Resumos SBFis/ALACF. , 2003. p.179 - 179

BASSOLI, B. K., MARIO, E. G., BORBA-MURAD, G. R., ZAIA, C. T. B. V., BAZOTTE, R. B., SOUZA, H. M.

32. Efeito do ácido clorogênico sobre a ação do glucagon na produção hepática de glicose, glicogenólise e glicólise In: XII Encontro Anual de Iniciação Científica, 2003, Foz do Iguaçú.

CD-ROM XII EAIC. , 2003.

BASSOLI, B. K., MARIO, E. G., BORBA-MURAD, G. R., ZAIA, C. T. B. V., BAZOTTE, R. B., SOUZA, H. M.

Efeito do ácido clorogênico sobre a ação do glucagon na produção hepática de glicose,

33. glicogenólise e glicólise In: I Simpósio Integrado dos Bacharelandos em Biomedicina e I Mostra de Painéis em Biomedicina, 2003, Londrina-PR.

CD-ROM I Simpósio Integrado dos Bacharelandos em Biomedicina e I Mostra de Painéis em Biomedicina. , 2003.

BORBA-MURAD, G. R., BASSOLI, B. K., MARIO, E. G., MORI, H., SOUZA, H. M., BAZOTTE, R. B.

34. Efeito insulin-like da leptina na neoglicogênese hepática In: III Congresso de Endocrinologia do IDEM, 2003, Maringá.

Livro de Resumos III Congresso de Endocrinologia do IDEM. , 2003. p.12 - 12

MARIO, E. G., MORI, H., BASSOLI, B. K., KAMEI, F. M., SISCAR, A., YAMABAYASHI, M., UTIDA, R., BAZOTTE, R. B., SOUZA, H. M.

35. Efeito insulin-like da leptina na neoglicogênese hepática a partir da L-alanina In: XVII Reunião Anual da Federação de Sociedades de Biologia Experimental, 2002, Salvador.

CD-ROM FeSBE 2002. , 2002. 
BASSOLI, B. K., MARIO, E. G., MORI, H., KAMEI, F. M., SISCAR, A., YAMABAYASHI, M., UTIDA, R., BAZOTTE, R. B., BORBA-MURAD, G. R., SOUZA, H. M.

36. Efeito insulin-like da leptina na neoglicogênese hepática a partir de L-alanina In: I Congresso paranaense de biologia aplicada à saúde/ V Congresso londrinense de biologia aplicada à saúde/ II Encontro paranaense de Biomedicina, 2002, Londrina.

Biosaúde. Londrina: UEL, 2002. v.4. p.27 - 27

BASSOLI, B. K., ESTEVÃO, D.

37. Nutracêutica e Alimentos Funcionais In: III Congresso Londrinense de Biologia aplicada à saúde, 2000, Londrina.

Biosaúde. Londrina: UEL, 2000. v.2. p.38 - 38

\section{Eventos}

\section{Participação em eventos}

Apresentação Oral no(a) XV Congreso Latinoamericano de Nutrición, 2009. (Congresso)

1. Folic acid (FA) chemopreventive activity during the inithial phases of hepatocarcinogenesis in rats.

Apresentação de Poster / Painel no(a) $\mathbf{1 0}^{\circ}$ Congresso Nacional da Sociedade Brasileira de

2. Alimentaçãa e Nutrição, 2009. (Congresso)

2. Suplementação com ácido fólico, danos no DNA e apoptose na etapa de promoção inicial da hepatocarcinogênese em ratos.

3. Treinamento de Análise Multivariada, 2008. (Outra).

Apresentação de Poster / Painel no(a) XII Semana Farmacêutica da USP, 2007. (Congresso)

4. Ácido fólico inibe a proliferação celular na etapa da promoção inicial da hepatocarcinogênese em ratos.

Apresentação de Poster / Painel no(a) $9^{\circ}$ Congresso Nacional da Sociedade Brasileira de

5. Alimentação e Nutrição, 2007. (Congresso)

5. Efeitos do ácido fólico na etapa de promoção inicial da hepatocarcinogênese em ratos dependem de sua dosagem.

6. $\quad 2^{\mathbf{o}}$ Simpósio Internacional da American Dietetic Association, 2007. (Simpósio).

7. I Simpósio de Pesquisa e Ensino em Nutrigenômica, 2007. (Simpósio).

8. São Paulo Research Conference-Cancer Today, from Molecular Biology to Treatment, 2007. (Simpósio).

9. Módulo de Educação Continuada: Aplicações da Bioestatística em Estudos de Nutrição, 2007. (Outra).

Apresentação Oral no(a) 21st International Conference on Coffee Science, 2006. (Congresso)

10. Bioassays to evaluate the physiological functional properties of chlorogenic acid and of an instant coffee extract with high levels of chlorogenic acids.

11. Apresentação de Poster / Painel no(a) $\mathbf{1 4}^{\mathbf{0}}$ Congresso Latino Americano de Nutrição, 2006. (Congresso) Propriedades funcionais dos ácidos clorogênicos do café.

12. Apresentação de Poster / Painel no(a) $6^{\circ}$ Simpósio Latino Americano de Ciência de Alimentos,

2005. (Simpósio) $6^{\circ}$ Simpósio Latino-Americano de Ciência de Alimentos.

13. $\mathbf{8}^{\circ}$ Congresso Nacional da Sociedade Brasileira de Alimentação e Nutrição, 2005. (Congresso).

14. I Simpósio da Sociedade Brasileira de Alimentos Funcionais, 2005. (Simpósio).

15. Curso: Alimentos Funcionais-6 ${ }^{\circ}$ Simpósio Latino Americano de Ciência de Alimentos, 2005. (Simpósio).

Apresentação de Poster / Painel no(a) I Mostra de Painéis de Pesquisa e Extensão do CCB, 16. 2004. (Outra) I Mostra de Painéis de Pesquisa e Extensão do CCB. 
17. Conferencista no(a) Jornada Integrada de Farmácia, Enfermagem e Nutrição, 2004. (Outra) Ministrou o mini-curso: Prebióticos e probióticos: conceitos e importância.

18. Apresentação Oral no(a) XII Encontro Anual de Iniciação Científica, 2003. (Encontro) Encontro Anual de Iniciação Científica.

Apresentação Oral no(a) I Simpósio Integrado dos Bacharelandos em Biomedicina e I Mostra

19. de Painéis em Biomedicina, 2003. (Simpósio)

I Simpósio Integrado dos Bacharelandos em Biomedicina e I Mostra de Painéis em Biomedicina.

20. $5^{\circ}$ Simpósio Latino Americano de Ciência de Alimentos, 2003. (Simpósio).

21. Food Ingredients South America-Ciclo de palestras Atualidades na Legislação de Alimentos, 2003. (Outra).

22. Food Ingredients South America-Programa de Conferências Alimentos Funcionais, 2003. (Outra).

23. Apresentação de Poster / Painel no(a) XVII Reunião Anual da Federação de Sociedades de Biologia Experimental, 2002. (Outra) Curso de Consumo Alimentar em Investigações Clínicas. Apresentação de Poster / Painel no(a) I Congresso paranaense de biologia aplicada à saúde / V

24. Congresso londrinense de biologia aplicada à saúde/ II Encontro paranaense de Biomedicina, 2002. (Congresso) Efeito insulin-like da leptina na neoglicogênese hepática a partir da L-alanina. Apresentação de Poster / Painel no(a) XVII Reunião Anual da Federação de Sociedades de

25. Biologia Experimental, 2002. (Congresso) Reunião Anual da Federação de Sociedades de Biologia Experimental.

26. Food Ingredients South America - Programa de Conferências sobre Ingredientes para Alimentos Funcionai, 2002. (Outra).

27. II Congresso de endocrinologia do IDEM, 2002. (Congresso).

28. Food Ingredients South America-Ciclo de palestras Alimentos Funcionais-aspectos tecnológicos, 2002. (Outra).

29. ${ }^{4}$ Simpósio

30. Apresentação de Poster / Painel no(a) III Congresso Londrinense de Biologia Aplicada à Saúde, 2000. (Congresso) Nutracêutica e Alimentos Funcionais.

31. Simpósio Alimentos Funcionais para o Novo Milênio: Qualidade de Vida e Saúde, 2000. (Simpósio).

32 Simpósio Internacional sobre perspectivas da pesquisa biomédica no século XXI, 2000. (Simpósio).

33. Curso Aplicações da Biotecnologia: utilizando clonagem gênica, sondas e PCR-III Congresso Londrinense de Biologia Aplicada à Saúde, 2000. (Outra).

34. O cardápio do terceiro milênio, 2000. (Congresso) 


\section{ANEXO V - Ficha do aluno}

Janus - Sistema Administrativo da Pós-Graduação

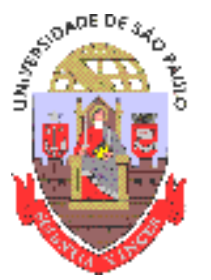

Universidade de São Paulo

Faculdade de Ciências Farmacêuticas

Documento sem validade oficial

FICHA DO ALUNO

\section{2 - 5081974/1 - Bruna Kempfer Bassoli}

Email:

brunakb@usp.br

Data de Nascimento: 02/10/1982

Cédula de Identidade: RG - 6.096.866-7 - PR

Local de Nascimento: Estado do Paraná

Nacionalidade: Brasileira

Graduação: Bacharel em Biomedicina - Universidade Estadual de Londrina - Paraná - Brasil - 2004 Mestrado: $\begin{aligned} & \text { Mestre em Ciência de Alimentos (1) - Universidade Estadual de Londrina - Paraná - Brasil - } \\ & 2006\end{aligned}$

Curso:

Programa:

Área:

Data de Matrícula:

Início da Contagem de Prazo: 05/04/2006

Data Limite:

$05 / 04 / 2010$

Doutorado
Orientador: Prof(a). Dr(a). Fernando Salvador Moreno - 05/04/2006 até o presente. E.Mail:

Ciência dos Alimentos

Nutrição Experimental

$05 / 04 / 2006$

rmoreno@usp.br

Proficiência em Línguas: Inglês, Aprovado em 05/04/2006

Data de Aprovação no Exame de Qualificação: Aprovado em 21/09/2009

Data do Depósito do Trabalho:

Título do Trabalho:

Data Máxima para Aprovação da

Banca:

Data de Aprovação da Banca:

Data Máxima para Defesa:

Data da Defesa:

Resultado da Defesa:

Histórico de Ocorrências:

Ingressou no Doutorado em 05/04/2006

Matrícula de Acompanhamento em 25/07/2009

Situação Atual: Matrícula de Acompanhamento em 25/07/2009

Impresso em: 29/11/09 00:08:23 
尹anus - Sistema Administrativo da Pós-Graduação

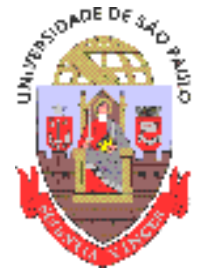

Universidade de São Paulo

Faculdade de Ciências Farmacêuticas

Documento sem validade oficial

FICHA DO ALUNO

\section{2 - 5081974/1 - Bruna Kempfer Bassoli}

Sigla

\section{Nome da Disciplina}

FBA5702- Compostos Bioativos em

$3 / 1$

NHA5705-

$1 / 1$

Alimentos e sua Relação com a

Saúde Humana

Fundamentos da Biologia

Molecular Aplicados à Nutrição

Humana (Curso Interunidades:

Nutrição Humana Aplicada -

Universidade de São Paulo)

FBA5728-

$2 / 4$

Aprimoramento Didático

Genética Molecular de Câncer

MCM5856

2/1

Universidade de São Paulo)

Tópicos Avançados em

FBF5781- Fármaco e Medicamentos

1/1 (Qualidade de Medicamento e

Biomateriais)

FBA5703- Tópicos em Tratamento de

$4 / 1$

Dados para Ciência e

Tecnologia de Alimentos

Fundamentos Biológicos da

NHA5701- Nutrição Humana Aplicada

3/4 (Curso Interunidades: Nutrição

Humana Aplicada -

Universidade de São Paulo)

FBA5901- Tópicos Avançados em

1/1 Nutrigenômica

Participou da Etapa de Estágio

Supervisionado em Docência do

Programa de Aperfeiçoamento

de Ensino junto à Disciplina

Atividade

FBA-0407 Fundamentos da

do

Programa

Análise Sensorial de Alimentos,

ministrada aos alunos de

01/02/2008 30/06/2008 -

graduação do curso de

Farmácia-Bioquímica da

Faculdade de Ciências

Farmacêuticas da Universidade

de São Paulo (2)

Métodos Avançados para

Análise de Dados de Estudos

HNT5740- Populacionais em Alimentação

1/1 e Nutrição (Faculdade de Saúde Pública - Universidade de São Paulo)
03/10/2006 30/10/2006 60

09/11/2006 13/12/2006 90

29/10/2007 02/12/2007 30

\section{Início Término \\ Carga} Horária

Cred. Freq. Conc. Exc. Situação

17/04/2006 23/04/2006 30

2

100.0 A

$\mathrm{N}$

Concluída

01/06/2006 06/07/2006 60

4

N

Concluída

23/05/2007 29/05/2007 30

2

100.0 A

$\mathrm{N}$

Concluída

11/06/2007 24/06/2007 60

4

$\mathrm{N}$

Concluída

06/08/2007 14/10/2007 120

8

75.0

A

$\mathrm{N}$

Concluída

2

100.0

$\mathrm{N}$

Concluída

0.0

$\mathrm{N}$

Matrícula

cancelada 


\begin{tabular}{|c|c|c|c|}
\hline & \multicolumn{2}{|c|}{ Créditos mínimos exigidos } & \multirow{2}{*}{ Créditos obtido } \\
\hline & Para exame de qualificação & $\|$ Para depósito de tese $\mid$ & \\
\hline Disciplinas: & 20 & 20 & 35 \\
\hline \multicolumn{4}{|c|}{ Atividades Programadas: } \\
\hline \multicolumn{4}{|l|}{ Seminários: } \\
\hline \multicolumn{4}{|l|}{ Estágios: } \\
\hline Total: & 20 & 20 & 35 \\
\hline
\end{tabular}

Créditos Atribuídos à Tese: 167

\section{Observações:}

1) Curso com validade nacional, de acordo com o disposto na Portaria MEC $n^{\circ} 2530$, de 06.09.2002.

2) Créditos atribuídos de acordo com o disposto na Portaria GR 3588, de 11.05 .2005 e aprovados pela Comissão de Pós-Graduação, em Sessão de 02/09/2008.

Conceito a partir de 02/01/1997:

A - Excelente, com direito a crédito; B - Bom, com direito a crédito; C - Regular, com direito a crédito; R - Reprovado; T - Transferência.

Um(1) crédito equivale a 15 horas de atividade programada.

Situação Atual: Matrícula de Acompanhamento em 25/07/2009

Impresso em: 29/11/09 00:08:23 
